INTER NATIONAL MONETARY FUND
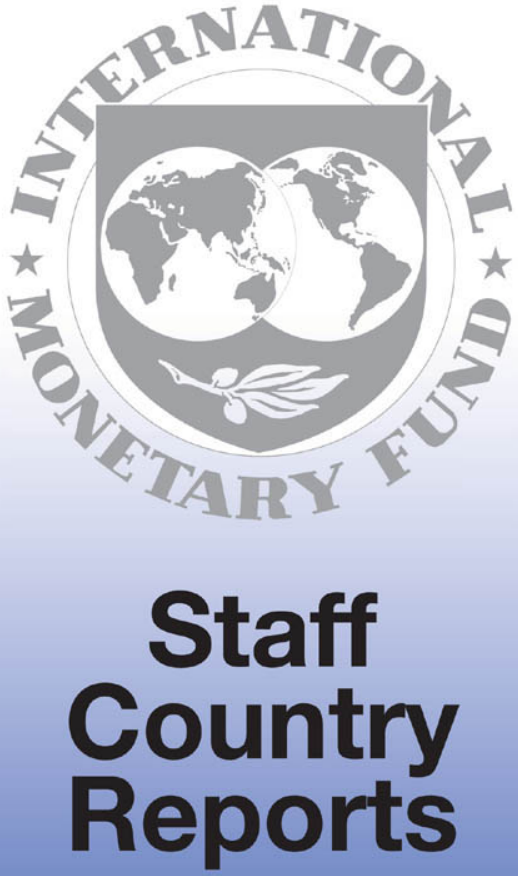


\section{Uruguay: Selected Issues}

This Selected Issues paper for Uruguay was prepared by a staff team of the International Monetary Fund as background documentation for the periodic consultation with the member country. It is based on the information available at the time it was completed on June 15, 2006. The views expressed in this document are those of the staff team and do not necessarily reflect the views of the government of Uruguay or the Executive Board of the IMF.

The policy of publication of staff reports and other documents by the IMF allows for the deletion of market-sensitive information.

To assist the IMF in evaluating the publication policy, reader comments are invited and may be sent by e-mail to publicationpolicy@imf.org.

Copies of this report are available to the public from

International Monetary Fund $\bullet$ Publication Services

700 19th Street, N.W. • Washington, D.C. 20431

Telephone: (202) 6237430 • Telefax: (202) 6237201

E-mail: publications@imf.org • Internet: http://www.imf.org

Price: $\$ 18.00$ a copy

\section{International Monetary Fund Washington, D.C.}


This page intentionally left blank 


\section{INTERNATIONAL MONETARY FUND}

\section{URUGUAY}

\section{Selected Issues}

Prepared by Marco Piñón, Herman Kamil, Harald Finger, Alejandro Hajdenberg, Jorge Iván Canales-Kriljenko, Gastón Gelos, and Stephanie Eble

Approved by Western Hemisphere Department

June 15, 2006

Contents

Page

I. Overview

II. Balance-Sheet Mismatches and Cross-Sectoral Vulnerabilities in a Highly Dollarized Economy: The Case of Uruguay ..................................

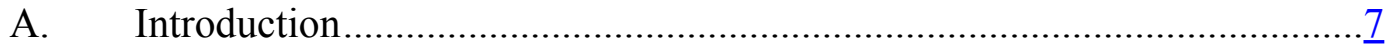

B. Economy-Wide Indicators ........................................................... 7

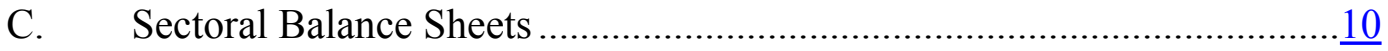

D. Cross-Sectoral Linkages ............................................................ 18

E. Exchange Rate-Induced Credit Risk of Domestic Banks .........................19

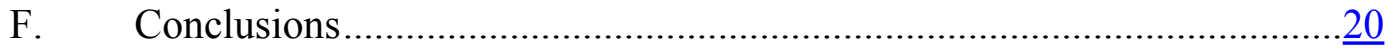

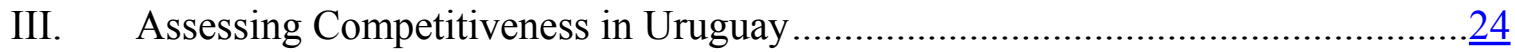

A. Introduction.............................................................................. 24

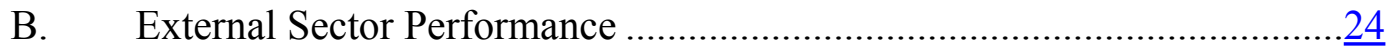

C. Competitiveness Indicators ..........................................................

D. Estimating an Equilibrium REER .................................................

E. International Competitiveness Rankings ............................................. $\underline{33}$

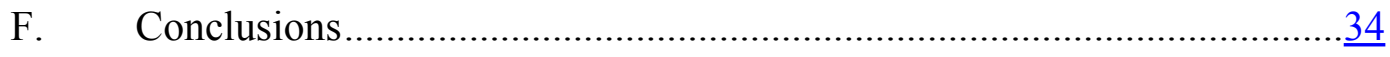

IV. Post-Crisis Credit: Facts, Lessons, and Prospects …................................... $\underline{36}$

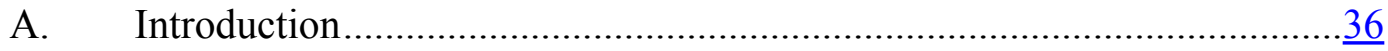

B. Evolution of Credit to the Private Sector........................................... 37

C. Has There been a Credit Crunch? …....................................................

D. Comparison with International Experience ........................................... 45

E. What should be done? .............................................................. 
V. Options to Increase Infrastructure Investment in Uruguay..............................53

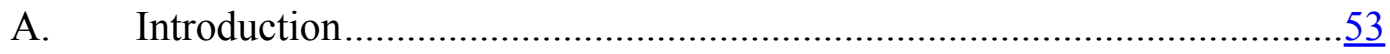

B. Public Investment and Growth in the Literature....................................

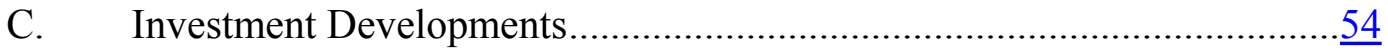

D. Options to Promote High Quality Public Investment .............................59

E. Public-Private Partnerships ...............................................................

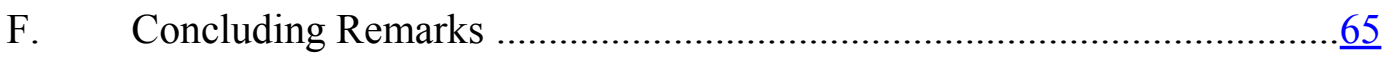

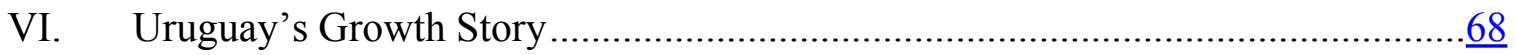

A. Introduction...............................................................................

B. Volatility and Growth Trends - The Facts .......................................... $\frac{68}{6}$

C. Explaining Uruguay's Growth—Traditional Models ............................ $\underline{70}$

D. Impact of External Factors on Uruguay's Growth-A Closer Look .......... 72

E. Conclusions - Looking Ahead.........................................................

Boxes

V. 1. Private Participation in Infrastructure in Uruguay..................................57

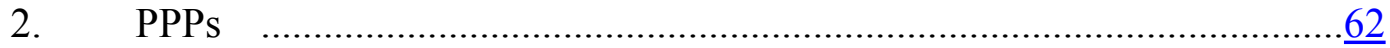

3. PPPs in Colombia and Chile ...........................................................

VI. 1. Measures Taken to Reduce the Risks Associated with Financial Linkages

Tables

II. $\quad$ 1. Asset Composition of Pension Funds' Portfolio.....................................

2. Currency Composition of Pension Funds' Portfolio..................................16

3. Currency Composition and Maturity Structure of Financial Liabilities of the Corporate Sector in Uruguay: December 2004 ..............16

4. Dollarization and Residual Maturity of Total Liabilities of the Corporate Sector in Latin American Countries .....................................17

5. Holders of Central Government Bonds................................................19

6. Share of Foreign Currency Credit of the Nontradable Sector in Total Credit..... .$\underline{20}$

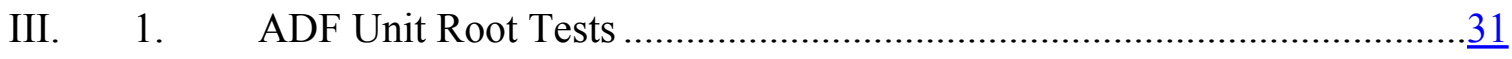

2. Selected VECM Results...............................................................

V. 1. Selected Fiscal Indicators, 1999-2005 ….........................................55

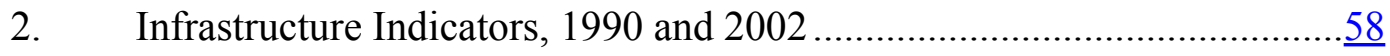


Figures

II. $\quad 1 . \quad$ Net External Debt Position of the Uruguayan Economy ............................. $\underline{8}$

2. External Maturity Mismatch of the Uruguayan Economy …....................... $\underline{9}$

3. Net Inward FDI Stock, as a share of Net Total External Financing ...........10

4. Share of Foreign-Currency Denominated Debt in total Sovereign

Debt, 2005 ................................................................................

5. Changes in Sovereign Debt Structure .................................................... 12

6. Share of Contractual Short-Term Debt in Total

Sovereign Debt, 2005 ...............................................................12

7. Foreign Currency Maturity Mismatch of the Consolidated

Public Sector ..........................................................................13

8. Share of Foreign Currency Deposits in Banking System, 2005 ................14

9. Banking System's Holdings of Sovereign Debt in Selected

Emerging Market Countries............................................................18

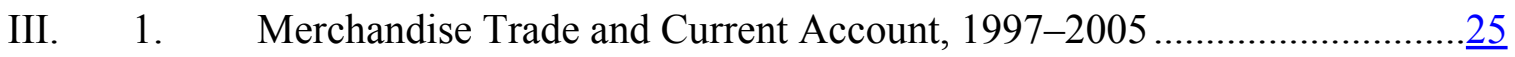

2. Market Shares in Selected Export Destinations, 1997-2005 ....................26

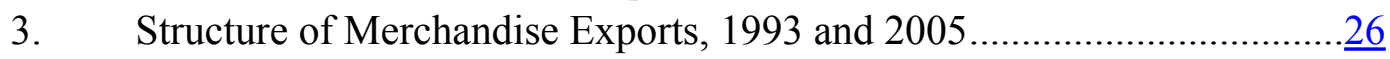

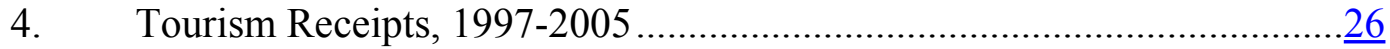

5. Foreign Direct Investment, 1997-2005 ................................................

6. Ratio of Tradable to Non-Tradable Prices .............................................. 27

7. Export Price Ratios .......................................................................

8. Real Exchange Rate Relative to Selected Trading

Partners, 1997-2005 .......................................................................

9. Exchange Rate and Per-Capita GDP, 2001-05 ..................................29

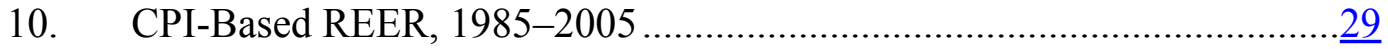

11. Real Effective Exchange Rates, 1997-2005 ........................................ $\underline{30}$

12. Actual and Estimated Equilibrium REER, 1998-2005...........................

IV. 1. Lending to Private Sector Around Selected Banking Crises .................... 47

2. Evolution of Deposits and Lending Around Selected Banking Crises ....... $\underline{48}$

V. 1. Public Investment in Selected Countries, 2005 .....................................55

2. Public Investment in Uruguay, 1999-2005 ...........................................55

3. Average PPI in Latin America, 1990-2004 ..........................................56

4. Public Sector Expenditure in 2005 .................................................. 
Appendices

II. Corporate Vulnerability to Exchange Rate Devaluations: Sensitivity

Test Results

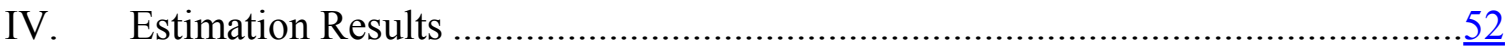

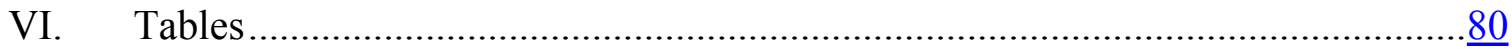




\section{OVERVIEW}

1. This report includes five background studies with emphasis on vulnerabilities and growth, the focus of the 2006 Article IV Consultation with Uruguay. The papers cover both longer-term, structural questions, as well as short-term issues.

2. The second chapter takes stock of key financial balance sheet vulnerabilities. It confirms the need to stay the course in following prudent policies as vulnerabilities have declined since the crisis, but remain important. For example, the public debt-to-GDP ratio has fallen, but is still higher than before the crisis. Savings of Uruguayan residents continue to be largely short term and denominated in foreign currency, while the government and most Uruguayan companies, the users of these savings, do not have steady income streams in foreign currency terms, and have most of their assets installed for the long term. Under a hypothetical sharp drop of the Uruguayan peso, government and companies may have difficulties honoring their dollar debt. Banks would be affected indirectly through their exposure to companies, and with them, stakeholders (including the public sector and households) will be ultimately hurt. The paper argues that developing markets for hedging Uruguayan peso risk could help reduce corporate and bank vulnerabilities.

3. The following chapter examines Uruguay's competitiveness. As a small open economy, Uruguay depends on international competitiveness for its economic development. With the appreciation of the peso since early 2004, the discussion about competitiveness has intensified. To assess competitiveness, the paper looks at balance of payments trends, the ratio of tradable to non-tradable prices, cost and profitability measures, and real exchange rates and their alignment with purchasing power parity (PPP). Most indicators suggest that Uruguay has remained competitive. An estimation of the equilibrium REER also supports the notion that peso is near equilibrium. However, while pointing to continued competitiveness, some indicators are on a declining trend. The paper argues that Uruguay should continue to improve the institutional and business environment to improve the ability of Uruguayan companies to compete internationally.

4. The evolution of domestic credit and likely prospects for economic activity and its financing are then examined, drawing lessons from other countries. To sustain growth into the medium term while avoiding a buildup of new vulnerabilities, private sector access to credit will be important. After falling for three years, bank credit stocks, reflecting both supply and demand factors, have now stabilized at low levels. Banks have been subject to stricter prudential rules and have been reluctant to lend to indebted borrowers, while companies may have been postponing investments. Econometric estimation, using a disequilibrium framework, do not suggest the prevalence of credit rationing. International evidence illustrates that after banking and currency crises, companies typically find other sources of finance, with bank credit picking up gradually after about three years. The study concludes that the current economic recovery is likely to continue, at least in the near future, despite slow credit growth, and suggests that further institutional reforms and the use of trust funds could help facilitate companies' access to finance. 
5. The fifth chapter reviews recent trends in investment in public infrastructure and examines ways to achieve higher infrastructure spending. Infrastructure in Uruguay is generally of good quality and coverage. Nevertheless, the decline in public investment since the crisis raises concerns about the prospects for maintaining the current quality of public services. There are indications of emerging infrastructure bottlenecks that could prevent sustaining strong economic growth into the medium term. The paper argues that addressing investment needs should involve both public and private sector participation. It provides recommendations to increase public investment, consistent with the fiscal constraints imposed by the still high level of debt. Also, in light of Uruguay's intentions to expand public sector participation through public-private partnership, the chapter draws lessons from international experience to strengthen Uruguay's institutional framework for establishing efficient and fiscally solid PPPs.

6. This sixth chapter discusses Uruguay's growth performance since the 1960s, focusing on the role of external factors and linkages to the region. Per capita growth in Uruguay has been low and volatility high by both regional and international standards. Periods of strong growth have been short and followed by deep recessions, closely tracking developments in Argentina. Much of Uruguay's long-term growth performance can be attributed to total factor productivity rather than capital accumulation. In a cross-country comparison, Uruguay's growth has been positively influenced by its high level of education and negatively by a volatile external environment. Following this insight, the paper takes a closer look at factors that have made Uruguay's growth vulnerable to external shocks. These include the high financial integration with Argentina, regional dependencies, and a reliance on commodities. While vulnerabilities have declined recently, Uruguay needs to further reduce its exposure to external shocks. 


\section{Balance-Sheet Mismatches ANd Cross-Sectoral Vulnerabilities in A Highly Dollarized ECONOMY: The CASE OF URUGUaY ${ }^{1}$}

\section{A. Introduction}

1. The paper takes stock of key financial balance-sheet vulnerabilities in Uruguay and compares them to their crisis and pre-crisis levels. It focuses on the risks from maturity, currency, and capital structure mismatches in different sectors of the Uruguayan economy and explores interrelations among them. The paper divides the economy into four sectors: public sector (including the central bank), banking sector (excluding the central bank), pension funds, and private nonfinancial companies and households.

2. Many structural weaknesses have decreased since the crisis, but important balance-sheet fragilities remain. Uruguay's external financial position has strengthened. Its exposure to reversals in external financing flows and withdrawals of nonresident deposits have declined. The FDI share in total external financing fell during the crisis, but has been recovering since then. Public debt has declined, but remains higher than before the crisis. Public debt and the financial system remain highly dollarized. Large currency and maturity mismatches persist at the sector level. For example, the public and corporate sectors have short open foreign exchange positions, while households and pension funds have long ones.

3. Balance-sheet interrelations transfer vulnerabilities across sectors. Two thirds of pension fund portfolios are invested in government debt, which exposes them to sovereign credit risk. In contrast with other countries in the region, banks' holdings of public debt have been traditionally low in Uruguay. Banks have granted a third of their dollar loans to industries with little export activity and are indirectly exposed to sharp peso depreciation.

\section{B. Economy-Wide Indicators}

\section{Uruguay's external financial position has substantially strengthened since the} onset of the crisis, but is still weaker than in 2001. Its net foreign debt position has declined by US\$1.3 billion during 2002-2005, reaching US\$7.5 billion (43 percent of GDP) in 2005. This, however, is still about US\$2 billion larger than in 2001, when net foreign debt was equivalent to 31 percent GDP (Figure 1).

\footnotetext{
${ }^{1}$ Prepared by Herman Kamil.
} 
Figure 1. Net External Debt Position of the Uruguayan Economy 1/
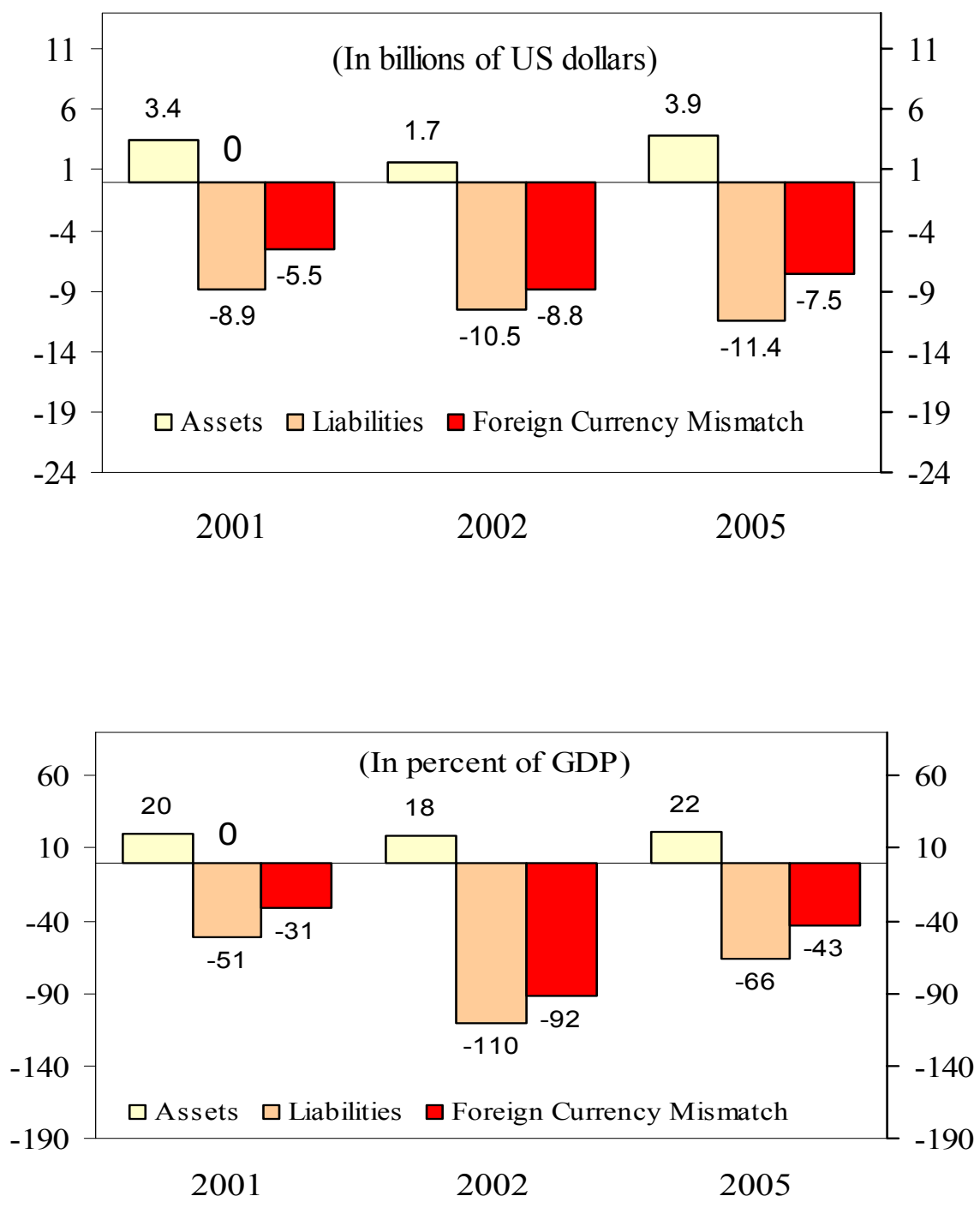

Source: Staff calculations based on Central Bank data

1/ The Figure plots, for each y ear: a) total external assets of the nonfinancial public sector and Central Bank ("Assets"), b) total external obligations of public and private sector ("Liabilities") and c) Net external Assets ("Foreign Currency Mismatch")

\section{Uruguay's exposure to reversals in short-term external financing flows and} sudden withdrawals of nonresident deposits has declined, even compared to pre-crisis levels. The net short-term debt of US\$2.8 billion in 2001 switched to a net short-term asset of US $\$ 1.7$ billion in 2005 (Figure 2). Banks' accumulation of short-term foreign currency assets and a significant reduction in nonresident deposits have made the banking system less 
vulnerable to changes in portfolio preferences in neighboring countries. While in 2001 nonresident deposits accounted for 50 percent of total private sector deposits, by end-2005 this ratio had declined to about 20 percent. Banks' liquid assets now cover more than twice the level of nonresident deposits, compared with about 80 percent in 2001.

Figure 2. External Maturity Mismatch of the Uruguayan Economy 1/
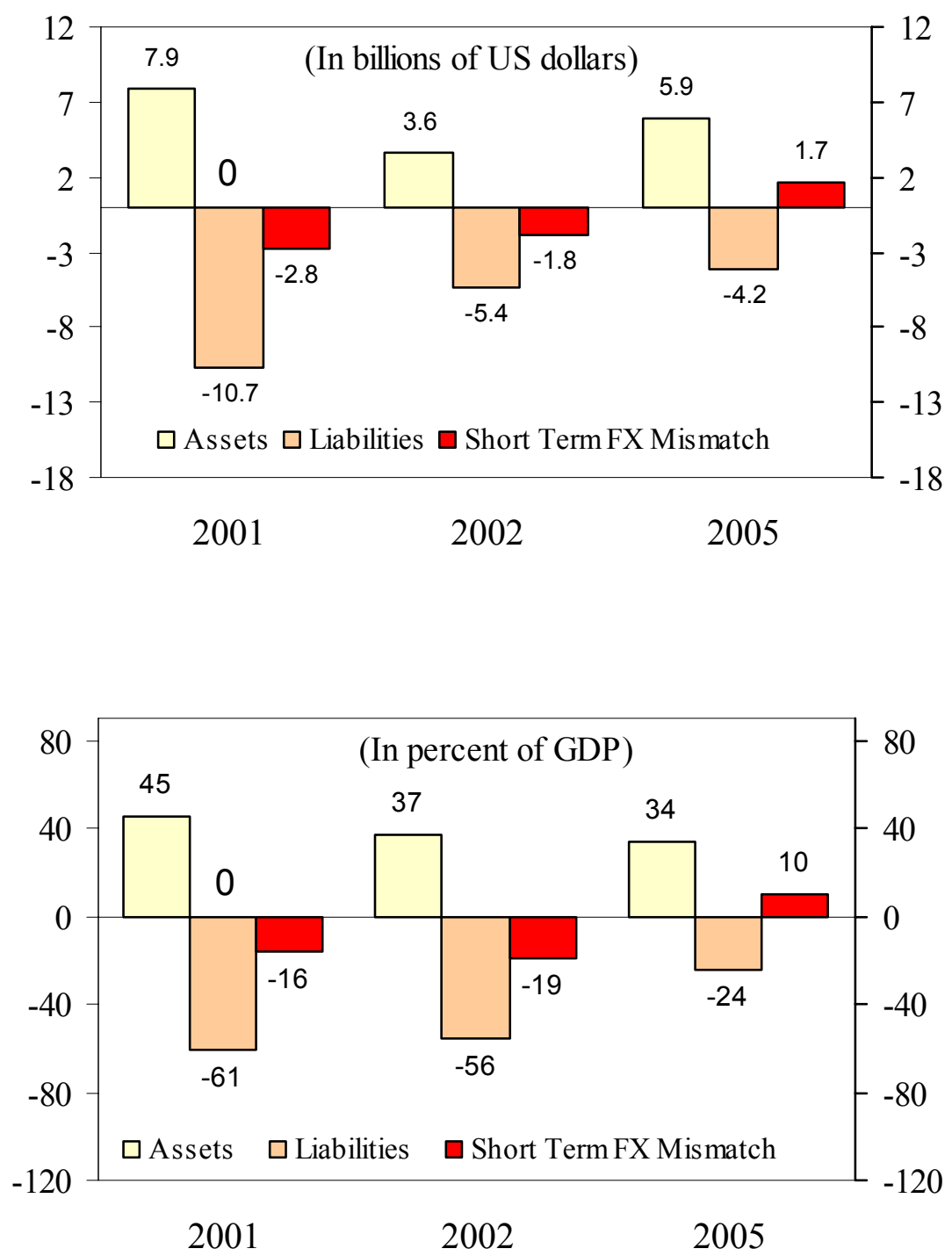

Source: Staff calculations based on Central Bank data

1/ The Figure plots, for each year: a) the sum of short-term, foreign currency external assets of the public sector, central bank (net of monetary base) and commercial banks ("Assets"), b) total short-term external debt and short-term nonresident deposits ("Liabilities") and c) Net short-term external assets ("Short Term FX Mismatch"). 
6. The share of equity financing has been recovering toward pre-crisis levels. After falling sharply with the crisis, Uruguay's “equity buffer" has systematically increased (Figure 3). The key advantage of FDI over debt financing is that its payoffs (profit and dividend remittances) are directly linked to the "capacity to repay." While profits and dividends fall in bad times, debt-service payments generally remain unchanged.

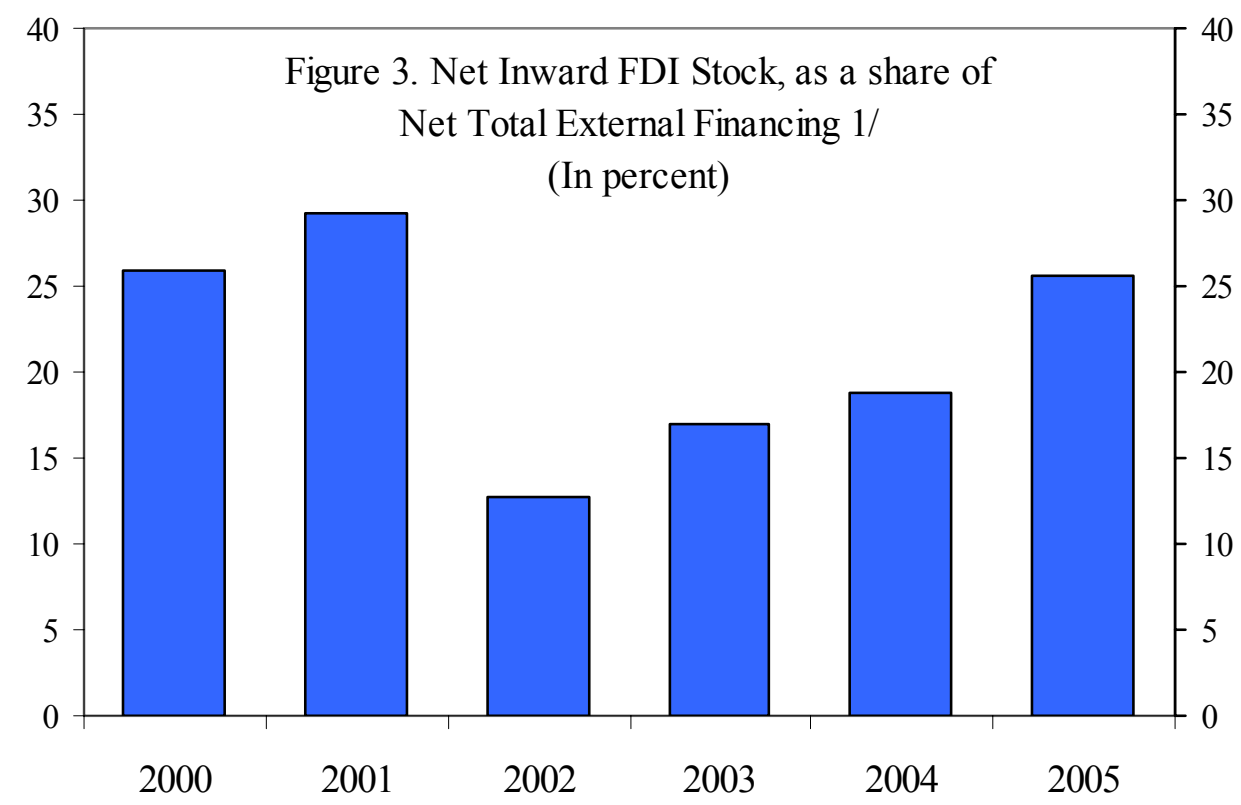

Source: Staff calculations based on Central Bank data.

1/ Net Inward FDI stock, as a percent of net external debt stock plus net inward FDI stock.

\section{Sectoral Balance Sheets}

7. The four sectors identified in the paper vary in the magnitude of their currency and maturity mismatches. Some of these sectoral mismatches partly offset each other in the aggregate, as for example, long open foreign exchange position of households contrast with the short open foreign exchange positions of the government and nonfinancial companies.

\section{Public sector (including the Central Bank)}

8. Public debt as a share of GDP has declined significantly, but is still higher than before the crisis. Strong growth, lower interest rates, peso appreciation, and the improved fiscal position have lowered the debt of the nonfinancial public sector and the central bank to GDP from 93 percent at end-2002 to 83 percent at end-2005. Yet, Uruguay's public debt-toGDP ratio is still much higher than in 2001 (53 percent) and well above the median value for 
a sample of 30 other developing countries at end-2005 (46 percent). The improvement is much stronger at the nonfinancial public sector level: from 96 percent of GDP in 2002 to 69 percent of GDP in 2005.

\section{Currency mismatches}

9. The public sector has a substantial short net foreign currency position. Foreign currency liabilities of the public sector largely exceed its foreign currency assets. Foreign currency denominated debt accounts for about 72 percent of GDP, while gross reserves account for about 20 percent of GDP and government deposits in commercial banks for only a few percentage points of GDP. Despite the increase in peso-indexed debt since the crisis, Uruguay's public debt is still one of the most dollarized in the world, with over 87 percent denominated in foreign currency (Figure 4). Balance-sheet risk arises from the natural mismatch between foreign currency debt obligations and peso revenue collection.

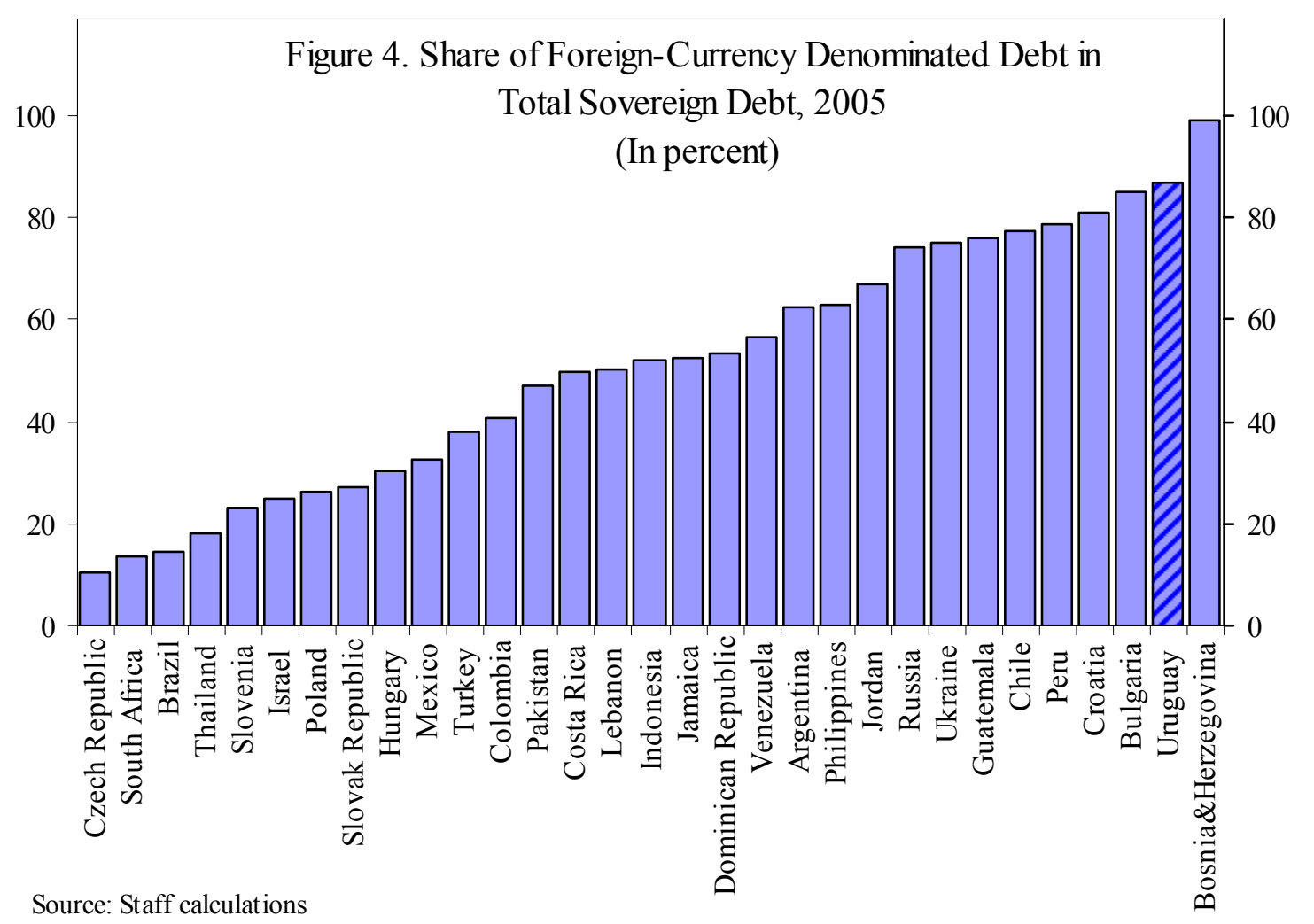

\section{Maturity mismatches}

10. Following the end-May 2003 debt exchange, the authorities have lengthened the public debt average maturity and smoothed its amortization profile (Figure 5). Average maturity of debt has increased from 6.1 years at end-2002 to 7.6 years at end-2005. While 
high dollarization of sovereign debt is a source of vulnerability, it has also allowed the government to extend the maturity of outstanding obligations. Indeed, dollarization has helped Uruguay maintain a low share of contractual short-term debt ( 3 percent), unlike many other developing countries (Figure 6).

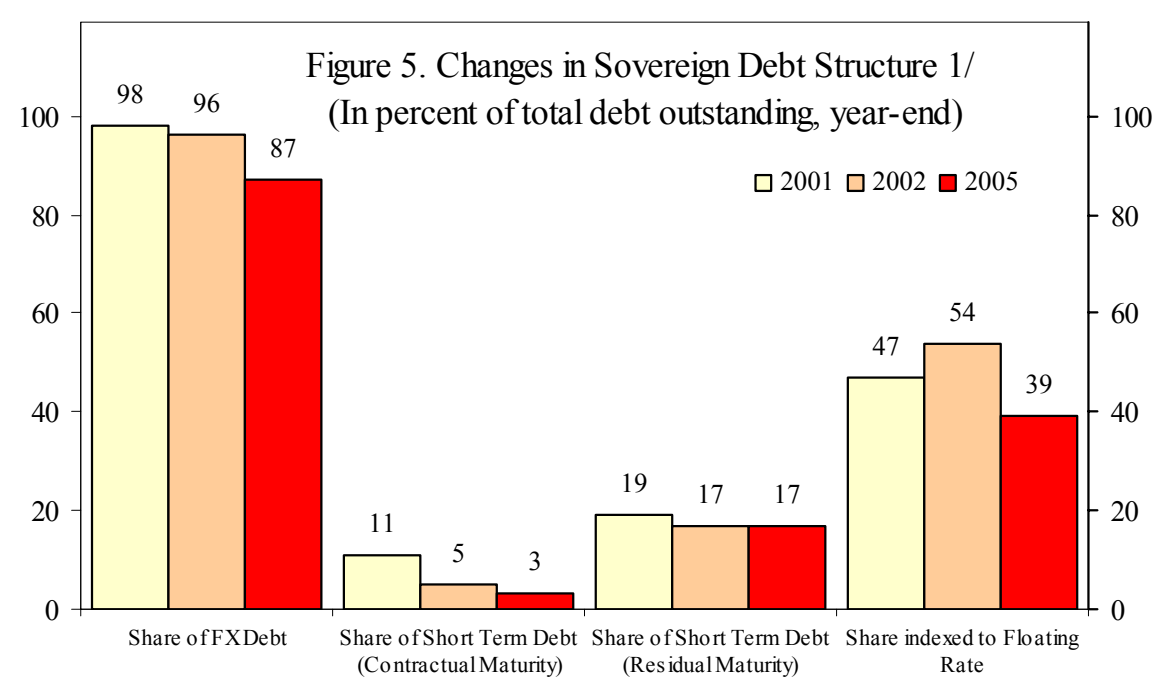

Source: Staff calculations based on Central Bank data

$1 /$ Most multilateral debt is indexed to a floating interest rate

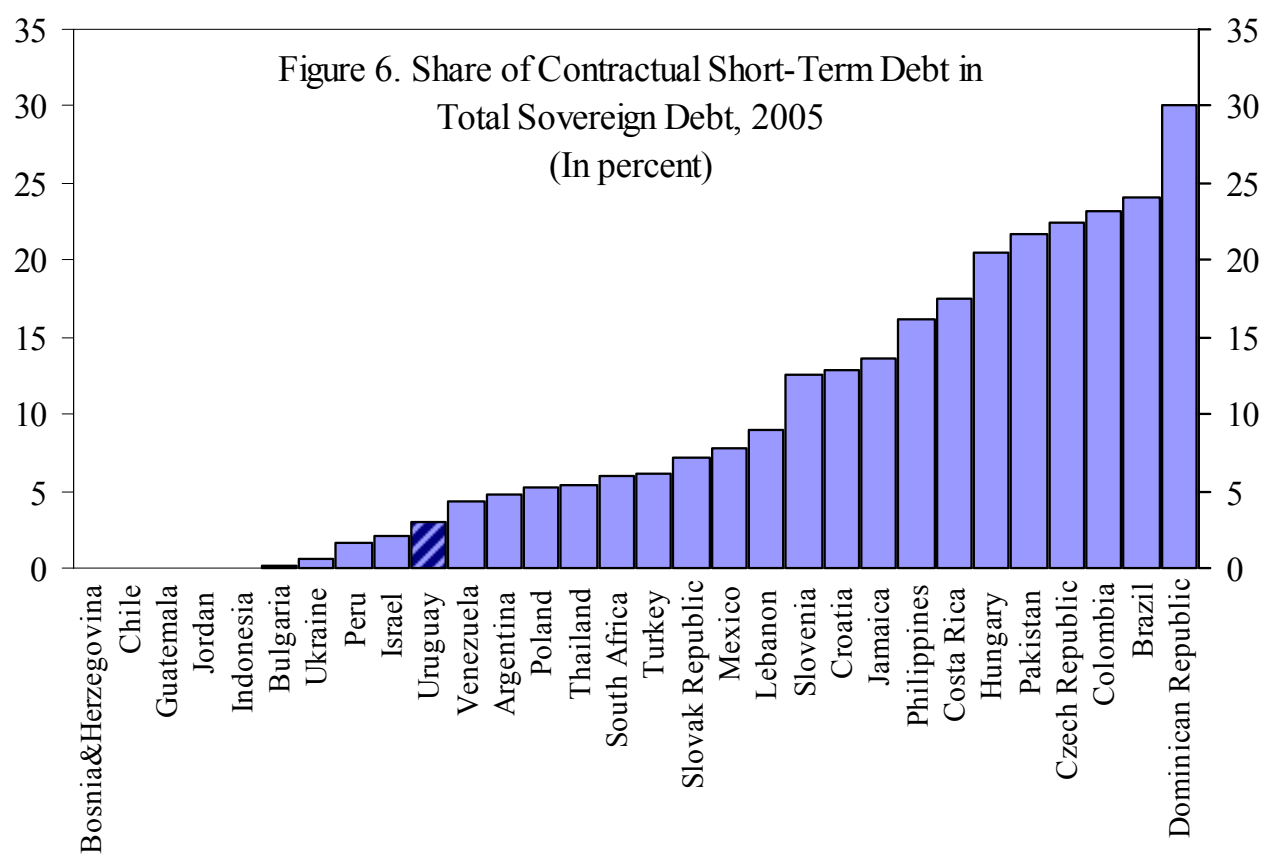

Sources: Staff calculations and data provided by National Authorities. 
11. The authorities have also increased liquidity cushions. At end-2005, gross reserves and government deposits in commercial banks exceeded short-term debt on a remaining maturity by US $\$ 1.4$ billion. This liquidity cushion is slightly higher than in 2001 , and a sharp contrast with the US\$1.1 billion liquidity shortfall in 2002 (Figure 7).

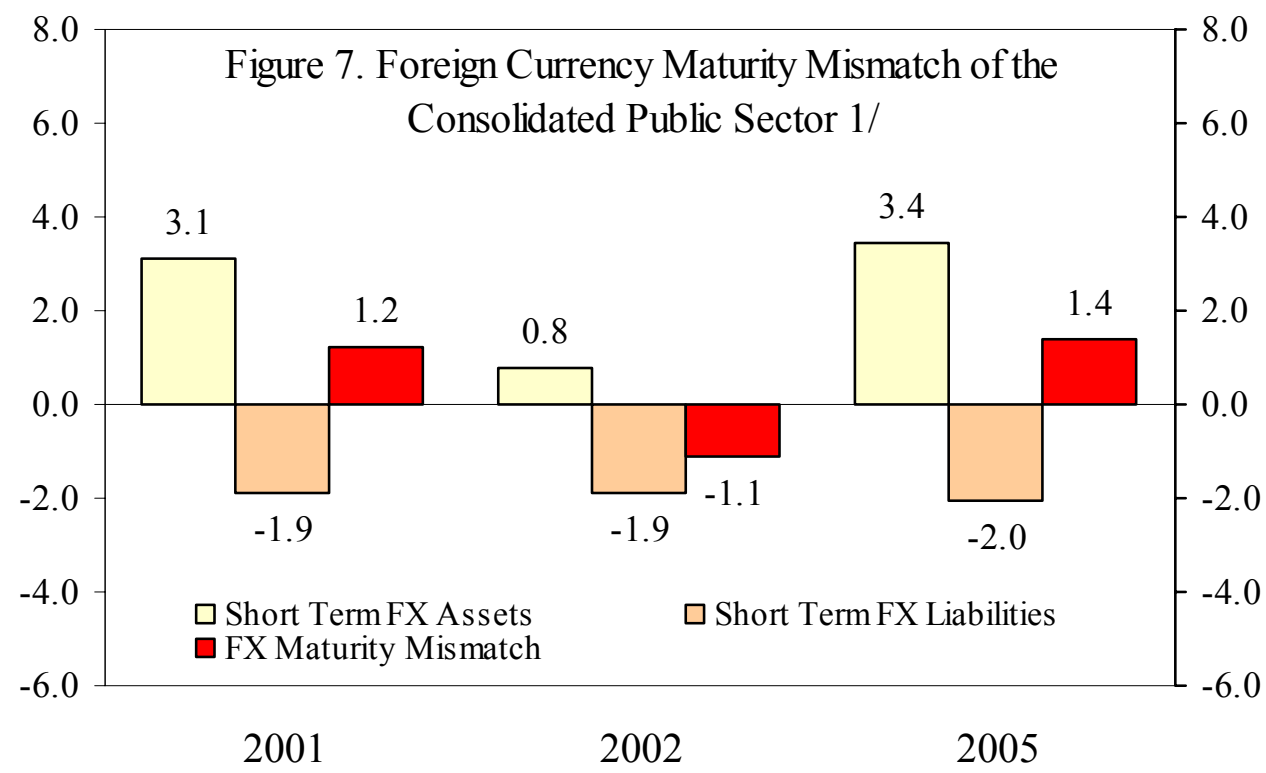

Source: Staff calculations based on Central Bank data

1/ The Figure plots, for each year: a) the sum of short-term, foreign currency assets of the public sector and central bank ("Short Term FX Assests"), b) total short-term domestic and external debt of the public sector denominated in foreign currency ("Short Term FX Liabilities") and c) Net short-term foreign currency assets ("FX Maturity Mismatch").

\section{Banking system (excluding the central bank)}

\section{Currency mismatches}

12. Uruguayan banks have positive net open foreign exchange positions. Banks net open positions have increased from US\$370 million in 2001 to US\$450 million in 2005. Prudential regulations allow such positions to be positive or negative but limit their size to 1.5 times bank capital. Typically, the limits are not binding, although banks' positions are usually positive; in 2005, they amounted to about 70 percent of capital. The value of dollar assets, however, can fall with peso depreciation (reducing the positive position) as some loans granted to companies with significant currency mismatches may become 
nonperforming and require provisions. Partly as a result of this, banks' net open foreign exchange position became temporarily negative by US\$1.5 billion during the 2002 crisis.

13. Financial sector dollarization has decreased only moderately, remaining among the highest in the world. Dollarization of outstanding resident deposits from the nonfinancial private sector has fallen from its peak of 90 percent to about 83 percent. Yet, it was among the highest among 121 developing countries, only below Cambodia and Liberia (Figure 8). Dollarization of credit has remained at about 70 percent in the period.

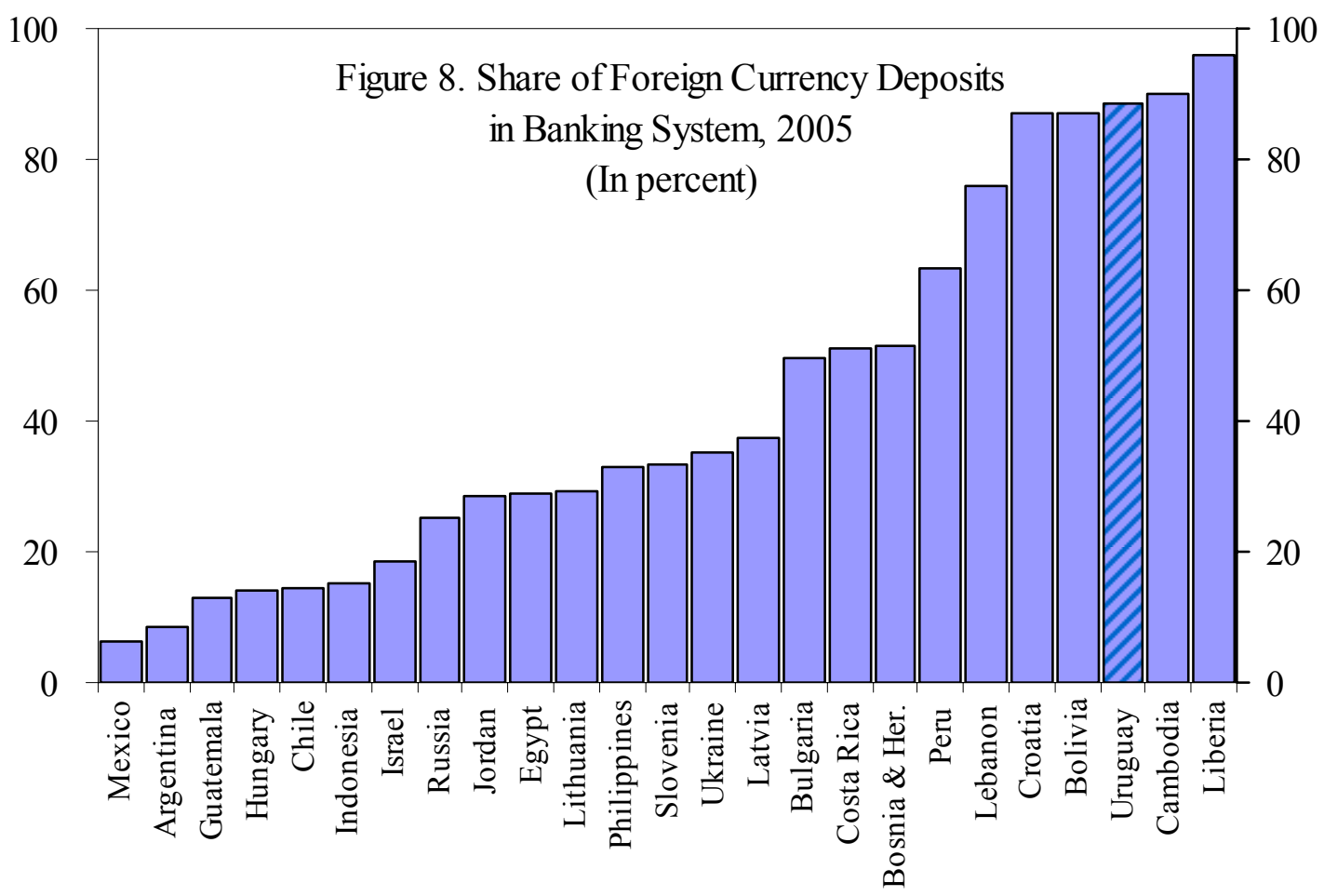

Sources: Levy-Yeyati (2006) and IMF staff estimates.

\section{Maturity mismatches}

14. Bank assets and liabilities generally have become significantly more liquid and the maturity mismatch has decreased. Banks have increased holdings of liquid assets (short-term foreign assets, central bank deposits and securities, and short-term government securities) from 34 percent to 52 percent of total assets between 2001 and 2005. This partly reflects the high dollar liquidity requirements imposed on specific banks for prudential reasons. While maturity of term deposits was typically under a year before the crisis, sight deposits have increased their share in total deposits from 30 to 65 percent during the period. 
The ratio of liquid assets to total deposits has risen from 49 to 82 percent. The increased liquidity is the flip side of the coin of low credit, which is partly explained by low credit demand and tightened credit standards (see Chapter IV).

\section{Pension funds}

15. Pension funds have a substantial long dollar position. Private pension funds in Uruguay (AFAPs) manage their customers' mandatory savings for retirement required by law. Pension funds compete with each other to attract contributors and provide an appropriate rate of return for these savings. The dollarization of pension fund portfolios has fallen from 81 percent in 2001 to 45 percent in 2005. The pension funds have a long foreign exchange position as they have basically no foreign exchange liabilities. In turn, pension funds have increased their share of inflation-linked securities to 48 percent of their portfolios, which only became available in larger supplies after the crisis (Tables 1 and 2).

Table 1. Asset Composition of Pension Funds' Portfolio

\begin{tabular}{lcc}
\hline & 2001 & 2005 \\
\hline & \multicolumn{2}{c}{ (In percent) } \\
Total & 100.0 & 100.0 \\
Central government & 61.2 & 59.5 \\
BCU and BHU & 5.1 & 24.7 \\
Time deposits and CDs & 16.6 & 7.9 \\
Corporate bonds and stocks & 4.3 & 1.1 \\
CRIs, financial trusts & 0.0 & 2.2 \\
Loans to affiliates & 1.7 & 0.9 \\
Cash & 11.1 & 3.7 \\
& & \\
Memo item: & & 2,153 \\
Value of portfolio (In millions of U.S. dollars) & 1,045 & \\
\hline
\end{tabular}

Source: Staff calculations based on Central Bank data 
Table 2. Currency Composition of Pension Funds' Portfolio

\begin{tabular}{lcc}
\hline & 2001 & 2005 \\
\hline \multicolumn{2}{c}{ (In percent) } \\
Total & 100.0 & 100.0 \\
Local currency & 19.0 & 54.9 \\
$\quad 18.4$ & 7.0 \\
$\quad$ Nominal Pesos & 0.6 & 47.9 \\
$\quad$ Indexed Pesos & 81.0 & 45.1 \\
Foreign Currency & & \\
& & \\
Memo item: & 1,045 & 2,153 \\
Value of portfolio (In millions of U.S. dollars) & & \\
\hline
\end{tabular}

Source: Staff calculations based on Central Bank data

\section{Companies and Households}

\section{Companies}

\section{Uruguayan companies continue to have substantial short open foreign exchange} positions. The 2005 annual survey of economic activity found that 80 percent of the companies (in a sample of 408 nonfinancial companies) had substantial dollar debt with short-term maturity at end-2004 (Table 3). Preliminary data suggests that the results carry over to 2005. The survey also found that about half the companies had short-term dollar obligations exceeding their annual dollar earnings. Of these companies, only 5 percent used derivatives to hedge its exposure to exchange rate risk. The companies with the highest net open foreign exchange positions were concentrated in manufacturing and transportation.

Table 3. Currency Composition and Maturity Structure of Financial Liabilities of the Corporate Sector in Uruguay: December 2004

(In percent)

\begin{tabular}{ccccccc}
\hline & \multicolumn{2}{c}{ Dollarization } & & \multicolumn{2}{c}{ Short Term Maturity } \\
\cline { 2 - 3 } \cline { 5 - 6 } & Mean & Median & & Mean & Median \\
\hline ALL FINANCIAL LIABILITIES & $\mathbf{7 2 . 1}$ & $\mathbf{1 0 0 . 0}$ & & $\mathbf{6 9 . 2}$ & $\mathbf{9 4 . 5}$ \\
\hline Bank Financial Liabilities & 77.0 & 100.0 & & 69.4 & 99.0 \\
Bond Financial Liabilities & 96.6 & 100.0 & & 38.6 & 33.1 \\
Other Financial Liaibilities & 52.1 & 92.0 & & 72.0 & 100.0 \\
\hline
\end{tabular}

Source: Staff calculations based on data collected in De Brun, Gandelman, Kamil, and Porzecanski (2006) 
17. The corporate sector remains vulnerable to market changes. Liability dollarization and short-term maturity of debt has remained high and almost unchanged with respect to 2001, even after controlling for exchange rate valuation effects. Uruguayan companies feature the highest ratios of liability dollarization and debt structures with the shortest maturities in Latin America (Table 4). Stress tests show that Uruguayan firms are resilient to the direct impact of moderate exchange rate shocks (Appendix). However, the indirect effect arising from a sharp drop in the dollar value in the income of companies selling nontradable goods to the domestic market would have a large toll.

Table 4. Dollarization and Residual Maturity of Total Liabilities of the Corporate Sector in Latin American Countries 1/

(Median values, in percent)

\begin{tabular}{cccccc}
\hline & \multicolumn{2}{c}{ Share of Foreign Currency } & & \multicolumn{2}{c}{ Share of Short Term Liabilities } \\
\cline { 2 - 3 } \cline { 5 - 5 } Uruguay & 2001 & 2004 & & 2001 & 2004 \\
Bolivia & $\mathbf{7 4 . 0}$ & $\mathbf{7 4 . 1}$ & & $\mathbf{9 5 . 8}$ & $\mathbf{9 0 . 3}$ \\
Peru & 84.2 & 71.1 & 51.3 & 44.7 \\
Argentina & 62.9 & 57.9 & 55.5 & 66.1 \\
Mexico & 67.9 & 54.9 & & 72.8 & 71.4 \\
Brazil & 30.0 & 17.3 & 53.7 & 45.9 \\
Colombia & 0.2 & 12.7 & 53.1 & 50.8 \\
Chile & 1.7 & 0.3 & 57.1 & 60.1 \\
\hline
\end{tabular}

Sources: De Brun, Gandelman, Kamil, and Porzecanski (2006), Kamil (2005) and Munyo (2005)

1/ Includes financial debt, supplier credit, and other liabilities.

\section{Households}

18. Households have a substantial positive net open foreign exchange position. Savings of Uruguayan residents in the domestic banking system (of about US\$ 7.6 billion) and in banks abroad (of some US\$5.4 billion) are largely denominated in U.S. dollars. ${ }^{2}$

${ }^{2}$ The paper assumes, for convenience, that resident nonfinancial private sector deposits belong to households. This assumption disregards working capital deposits by companies. Credit series distinguish between households and companies. 
Household loans from the domestic banking system amount to US\$530 million at end-2005, of which 75 percent is in domestic currency.

19. Households have accumulated significant assets in private pension funds since their introduction in 1993. As pension funds invest most of households' savings in government securities, households have become more exposed to the public sector. Thus, a previously implicit public sector liability - the net present value of expected pension payments -has become explicit in the form of government securities held by pension funds.

\section{Cross-Sectoral Linkages}

\section{Exposure to domestic government debt}

20. Banks' exposure to public sector assets has remained relatively small. Banks hold less than 10 percent of their assets in government debt and bank holdings account for only 5 percent of the stock of government securities. This direct bank exposure to the government is low compared with other emerging market countries (Figure 9). However, state banks' exposure to the public sector has indirectly increased as a result of higher levels of stateguaranteed debt in the aftermath of the crisis. Considering the government guarantee on BROU's claims on BHU and the trust funds with nonperforming loans formerly on the books of BROU, the exposure of the banking system to the sovereign would increase to 14 percent.

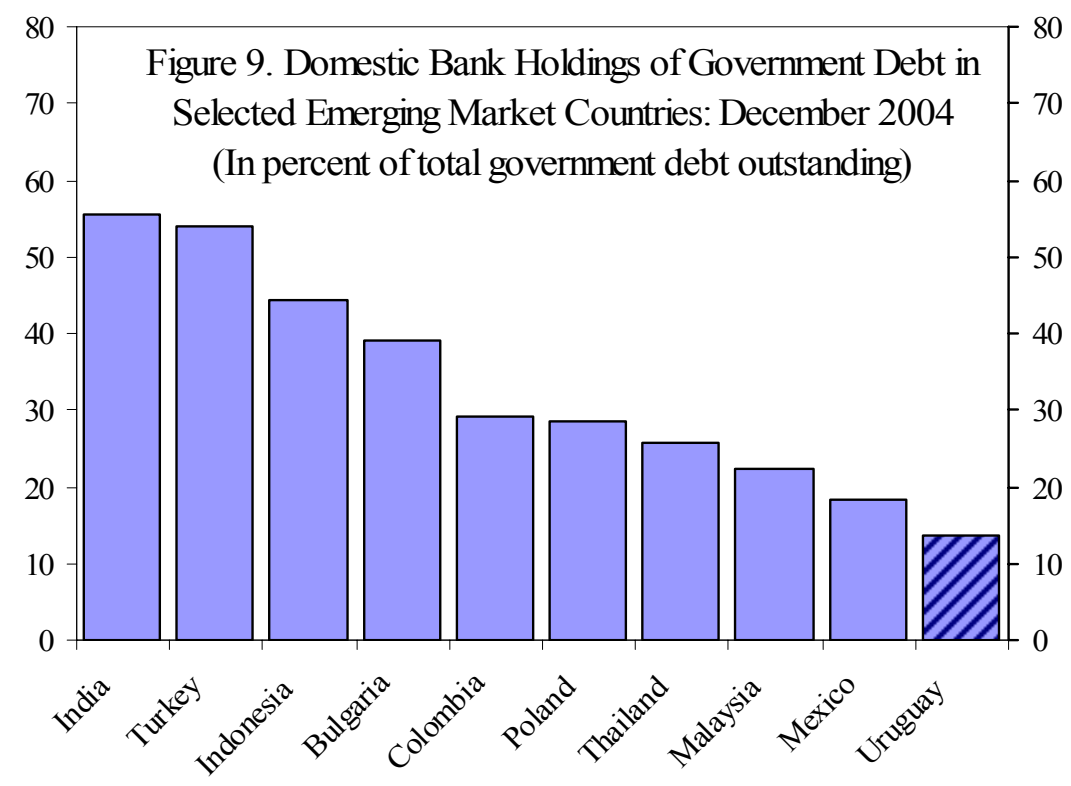

Source: Global Financial Stability Report (2006)

21. Pension funds are heavily exposed to sovereign risk. They are the principal institutional investors in Uruguay, managing more than US\$2 billion at end-2005. Some of the investment limits on the issuer, currency denomination, and jurisdiction of the securities pension funds are close to binding. About 60 percent of pension fund portfolios are invested in government securities, of which 40 percent are dollar-denominated and the remainder 
inflation-indexed. The share of government securities in pension fund portfolios is similar to that in Argentina, Colombia, and Mexico, but much larger than those in Brazil and Chile. Pension fund holdings of central government domestic debt account for half of the holdings of domestic residents (Table 5). Pension fund investments in nonfinancial private-sector instruments are about 3 percent and well below the limits, reflecting their small supply.

Table 5. Holders of Central Government Bonds

(Stock of Domestically-Issued debt at year-end)

\begin{tabular}{lrrrrr}
\hline INVESTOR BASE & 2001 & 2002 & 2003 & 2004 & 2005 \\
\hline & & (In millions of U.S. dollars) & \\
TOTAL & 2,285 & 1,690 & 2,336 & 2,433 & 2,467 \\
Held by Foreign Investors & 949 & 650 & 1,135 & 997 & 661 \\
Held by Domestic Investors & 1,336 & 1,041 & 1,201 & 1,435 & 1,806 \\
& & & & & \\
& & (In percent of total debt) & & \\
Held by Foreign Investors & 41.5 & 38.4 & 48.6 & 41.0 & 26.8 \\
Held by Domestic Investors & 58.5 & 61.6 & 51.4 & 59.0 & 73.2 \\
$\quad$ Banks and quasi-banks & 19.1 & 17.3 & 4.2 & 13.6 & 5.1 \\
Insurance companies & 1.3 & 3.4 & 1.6 & 1.5 & 1.7 \\
Mutual funds & 2.5 & 0.0 & 0.0 & 0.0 & 0.0 \\
Pension funds, social security schemes & 6.9 & 19.3 & 27.9 & 28.1 & 34.6 \\
Central bank & 0.0 & 0.0 & 0.0 & 0.0 & 0.0 \\
Non-financial public sector & 0.0 & 0.0 & 0.0 & 0.0 & 0.0 \\
Non-financial corporate & 16.1 & 9.8 & 16.0 & 14.3 & 17.5 \\
Retail & 12.5 & 11.6 & 1.7 & 1.5 & 14.3 \\
\hline
\end{tabular}

Source: Staff calculations based on data from Central Bank

\section{E. Exchange Rate-Induced Credit Risk of Domestic Banks}

22. Banks' exposure to credit risk arising from dollar lending to borrowers without dollar earnings has fallen. While banks would, in principle, benefit from peso depreciation given their long net open foreign exchange position, balance sheets would deteriorate because part of their portfolio would become nonperforming. Yet, banks credit risk exposure has diminished because the size of the dollar loan portfolio has declined and the share of dollar loans to the nontradable sector in total dollar credit has fallen from 46 to 31 percent during 2003-2005 (Table 6). Nevertheless, exchange rate-induced credit risk remains a significant issue for Uruguay. 
Table 6. Share of Foreign Currency Credit to the Nontradable Sector in Total Credit 1/

\begin{tabular}{|c|c|c|c|}
\hline & 2003 & 2004 & 2005 \\
\hline Banking System & 45.9 & 34.3 & 30.7 \\
\hline Banks 2/ & 44.9 & 32.7 & 29.7 \\
\hline mean (simple average) & 49.1 & 38.7 & 36.0 \\
\hline Financial Houses 2/ & 44.9 & 32.7 & 29.7 \\
\hline mean (simple average) & 40.2 & 34.5 & 34.4 \\
\hline Cooperatives $2 /$ & 36.4 & 31.8 & 34.2 \\
\hline mean (simple average) & 57.5 & 48.8 & 34.5 \\
\hline
\end{tabular}

\section{F. Conclusions}

23. Financial dollarization is at the heart of significant-albeit reduced-balancesheet vulnerabilities in Uruguay. Savings of Uruguayan residents continue to be largely denominated in foreign currency, while the government and most Uruguayan companies, the users of these savings, do not have steady income streams in foreign currency terms. In terms of currency exposures, the long position of households has been used to help finance the short position of the government and companies. However, under a sharp drop in the real value of the Uruguayan peso, government and companies may not be able to honor their dollar debt. Banks would be indirectly affected through their exposure to companies, and if banks fail, stakeholders (including the public sector and households) will be ultimately hurt. Pension funds manage the mandatory savings of households and fluctuations in the real value of their portfolio would ultimately also affect households.

24. The high public debt also poses important challenges. While short terms risks have declined, large and sustained changes in market sentiment would pose risks for macroeconomic stability. Within the Uruguayan economy, the pension funds are particularly exposed to sovereign risk. While banks' sovereign exposure is small, they would be affected by a worsening in economic conditions.

25. The government should stay the course to reduce dollarization and the high public debt. Continued large primary surpluses are needed to further bring down public debt 
as envisaged by the government. Consolidating a track record of prudent monetary management and flexible exchange rates would help entrench low inflation and discourage dollarization. Maintaining the policy of internalizing the risks of dollar lending to unhedged borrowers could further help reduce dollarization. Debt management could continue to gradually reduce the dollar share of public debt as peso savings increase and help offer attractive peso instruments.

26. Since currency preferences change slowly, developing markets for hedging Uruguayan peso risk could help reduce corporate and bank risks. Such a market would increase efficiency by transferring exchange rate risk to those better willing and able to bear it. The participation of foreign investors would be desirable given that Uruguay's export base, while increasing, is still small. Beyond continued exchange rate flexibility, this would require further developing money markets and a reliable yield curve on peso securities.

\section{References}

De Brun, Julio, Néstor Gandelman, Herman Kamil, and Arturo Porzecanski, 2006, "The Fixed-Income Market in Uruguay," mimeo IADB.

Kamil, Herman, 2005, “A New Database on the Currency Composition and Maturity Structure of Firms' Balance Sheets in Latin America: 1990-2004,” mimeo IADB.

IMF, 2005, "Debt-Related Vulnerabilities and Financial Crises: An Application of the Balance Sheet Approach to Emerging Market Countries," IMF Occasional Paper, forthcoming.

Levy-Yeyati, Eduardo, 2006, "Financial Dollarization: Evaluating the Consequences," Economic Policy (forthcoming).

Munyo, Ignacio, 2005, “The Determinants of Capital Structure: Evidence from an Economy without a Stock Market,” Draft Universidad de la República (September). 


\section{CORPORATE VULNERABILITY TO EXCHANGE RATE DEVALUATIONS: SENSITIVITY TEST RESULTS}

This section analyzes companies' vulnerability to peso depreciation at end-2004. It quantifies possible financial stress arising from unhedged currency mismatches in companies' balance sheets using a unique data set of nonfinancial companies.

The data source is the 2005 official annual survey of economic activity conducted by the Uruguayan National Statistical Institute. The database provides detailed information for 2004 to measure balance-sheet currency mismatches in a sample of 408 nonfinancial companies. Available variables include the stock of foreign currency financial and nonfinancial debt, the share of short-term liabilities, the share of exports in total sales, the currency structure of interest expenses, the sources of financing (supplier credit, banks, bonds and retained earnings) and the companies' forward exchange rate positions, if any.

The tests examine the effect of peso depreciation on nonfinancial companies' liquidity and solvency. The portfolio of each company was stressed to nominal peso depreciation ranging from 5 to 100 percent. The tests define that a company becomes financially stressed when it cannot meet its short-term obligations (liquidity effect) or its equity position turns negative (solvency effect).

The results show that the corporate sector is resilient to the direct impact of moderate exchange rate shocks. Appendix Table 1 suggests only 6 percent of companies (accounting for 7 percent of sales) will be under financial distress with 20 percent peso depreciation. The share of affected firms increases with larger shocks, reaching 27 percent of the companies (accounting for 41 percent of sales) with 100 percent peso depreciation.

\section{Appendix Table 1. Stress Test Results of the Corporate Sector to an Exchange Rate Depreciation}

\begin{tabular}{|c|c|c|c|c|c|c|c|}
\hline & \multicolumn{6}{|c|}{ Percent nominal depreciation } & \multirow[b]{2}{*}{100} \\
\hline & 5 & 10 & 20 & 40 & 60 & 80 & \\
\hline & \multicolumn{6}{|c|}{ (In percent of total firms in the sample) } & \\
\hline Firms in distress & 1 & 3 & 6 & 11 & 18 & 22 & 27 \\
\hline $\begin{array}{l}\text { Importance of distressed firms in } \\
\text { terms of }\end{array}$ & & & & cent & & & \\
\hline Sales & 2 & 3 & 7 & 12 & 36 & 41 & 47 \\
\hline Employment & 1 & 2 & 12 & 15 & 21 & 26 & 29 \\
\hline Assets & 2 & 4 & 11 & 17 & 33 & 38 & 43 \\
\hline Financial Liabilities & 4 & 9 & 17 & 28 & 45 & 51 & 60 \\
\hline
\end{tabular}

Source: Staff calculations based on data collected in De Brun, Gandelman, Kamil, and Porzecanski (2006) 
These results should be considered as the smallest possible effect of depreciation on companies for several reasons. First, the tests only consider the direct effect of depreciation, disregarding the likely evolution of other variables, like an increase in interest rates. Second, the tests only consider the effect of depreciation on financial debt. Third, the tests only consider companies with initial healthy financial positions, not to contaminate the results with companies near bankruptcy. Finally, the tests assume that the value of dollar earnings does not change, whereas companies selling nontradable goods to the domestic market usually experience falls in their dollar income. 


\section{Assessing Competitiveness In URUguaY ${ }^{1}$}

\section{A. Overview}

1. International competitiveness is of key importance to Uruguay, given the significance of sustained export growth for its economic development potential. Given the small size of the Uruguayan economy, export markets are key for domestic companies to seek economies of scale. Moreover, foreign direct investment, which tends to develop favorably under conditions of sustained competitiveness, can play a vital role in boosting productivity. Following a marked real depreciation of the peso during the 2002 crisis, the real effective exchange rate (REER) has been appreciating since early 2004. While Uruguay's REER remains around 20 percent below its pre-crisis level, some observers have asked whether the recent trend of real appreciation may have led to a problem of competitiveness.

2. This chapter assesses Uruguay's competitiveness, against the backdrop of substantial fluctuations in exports and the REER during the last decade. Section B examines balance of payments trends, including recent export performance and market destinations. Section C looks at competitiveness from the perspective of several indicators, including the ratio of tradable to non-tradable prices, cost and profitability measures, as well as real exchange rates and their alignment with purchasing power parity (PPP) and the income level. Section D presents an estimation of the equilibrium REER and, while recognizing the limitations of this quantitative approach, provides an interpretation regarding the degree of the peso's alignment. Section E presents Uruguay's position in international competitiveness rankings. Conclusions are presented in Section F.

3. The majority of indicators suggests that Uruguay has remained competitive. Export performance has remained buoyant; Uruguay attracts increasing amounts of FDI; and most competitiveness indicators suggest that the tradable goods sector has remained attractive, including in relation to the non-traded sector. Uruguay's CPI-based REER remains substantially more depreciated than before the crisis and appears to be roughly in line with international experience after accounting for productivity differentials. Quantitative analysis suggests that the REER is not far from its equilibrium level. While elements of judgment are inevitable, the presented indicators thus support the notion that Uruguay's competitiveness is not out of line. However, some of the presented indicators, while pointing to continued competitiveness, are on a declining trend, and Uruguay should continue to improve its institutional and business environment that affect competitiveness from a structural angle.

\section{B. External Sector Performance}

4. A current account near balance, despite increased foreign investment and imports, suggests that Uruguay has remained competitive (Figure 1). Following the immediate post-crisis recovery, exports have continued to grow at a healthy pace, posting

\footnotetext{
${ }^{1}$ Prepared by Harald Finger (PDR)
} 
20 percent annual growth (17 percent in volume terms) in 2005 , well above the 30 -year historical average of 9 percent. Imports, which had contracted more than exports during the crisis, have shown even higher growth since the recovery, reflecting higher investment, the revival of domestic demand, as well as increased import prices for commodities such as oil. The current account deficit of $1 / 2$ percent of GDP was significantly smaller than the 30 -year historical average ( 2 percent), and more than covered by FDI alone.

Figure 1. Merchandise Trade and Current Account, 1997-2005
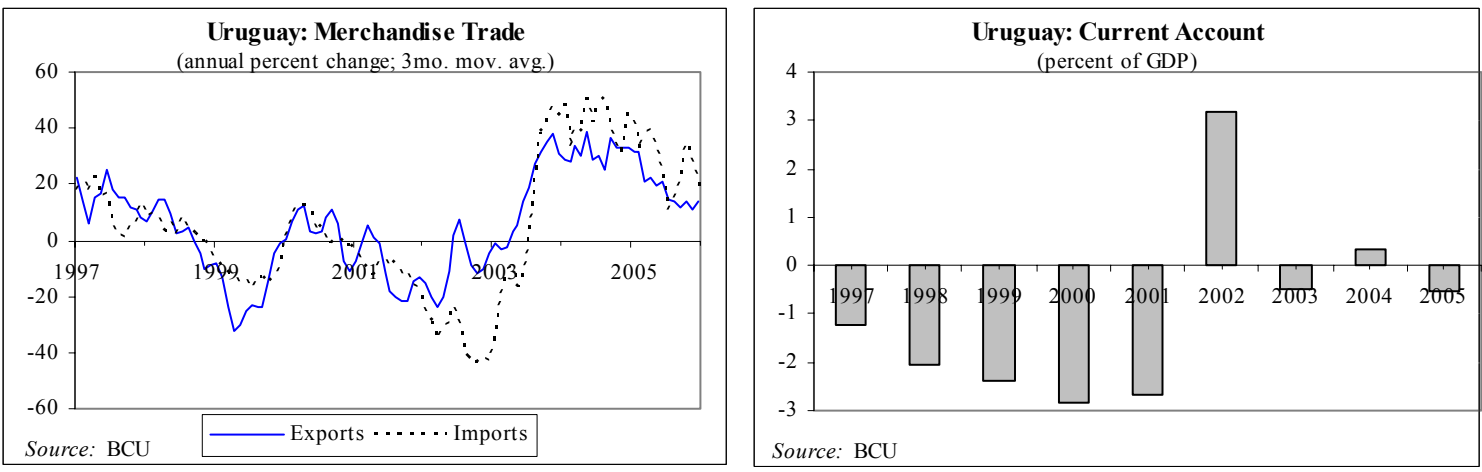

5. Uruguay's share in world export markets declined through the recession and crisis years, but has started to recover since 2003 (Figure 2). While Uruguay's market share in exports to its two large neighboring countries, Argentina and Brazil, has been declining over the last few years, it has been offset by an increased export market share in the U.S., with exports to the U.S. now of similar magnitude than those to Mercosur. While this has increased export market diversification, the concentration in agricultural exports, especially beef, has increased (Figure 3). Exports of wood and wood products have also been rising, while manufacturing exports have been essentially stable, with the exception of textile exports, which have been declining. Shifts are also evident in tourism revenue (Figure 4). While Argentina remains the most important source of tourism receipts, its importance has been declining relative to inflows from Brazil and the EU.

6. Inflows of foreign direct investment have increased strongly, a telltale for Uruguay's attractiveness as a location for investment (Figure 5). From the late 1990s, and interrupted only briefly by the 2002 crisis, net foreign direct investment inflows have grown substantially, and are now higher than in Argentina and Brazil as percentage of GDP. While in 2005 this partly reflects initial investments of the pulp mill projects, the upward trend has been apparent during the last decade, illustrating that it is broad-based. 
Figure 2. Market Shares in Selected Export Destinations, 1997-2005 (In percent)
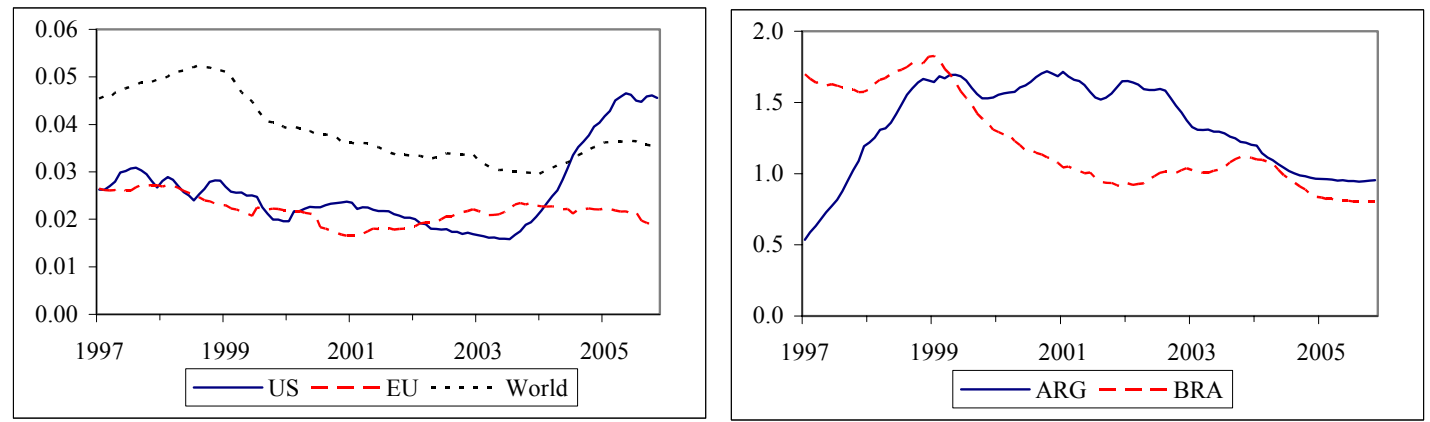

Figure 3. Structure of Merchandise Exports, 1993 and 2005

(In percent of total)

1993

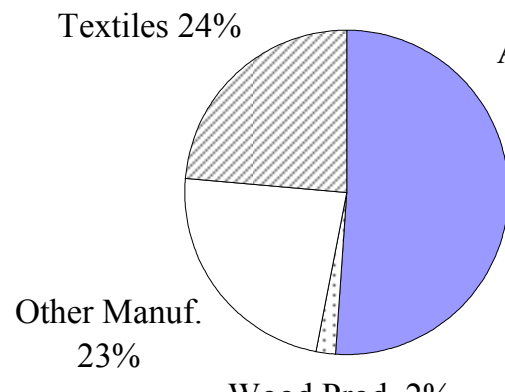

Wood Prod. 2\%

$23 \%$
Agri. Prod. $51 \%$

W

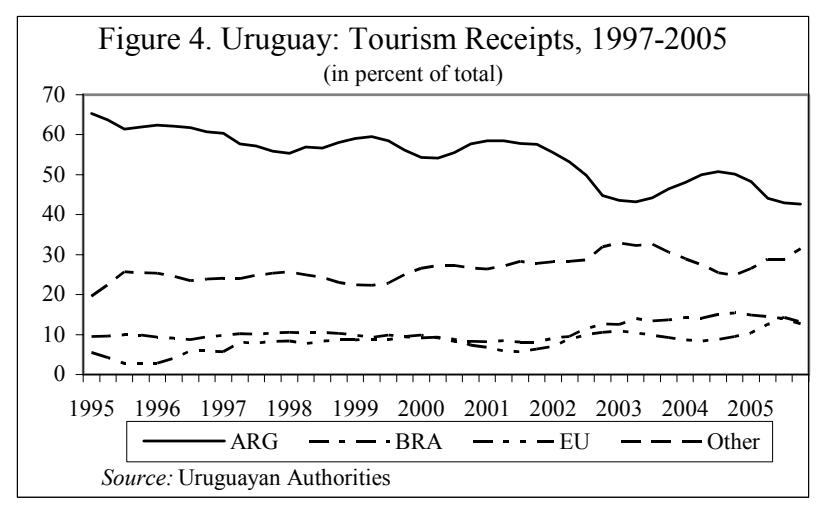

Figure 5. Foreign Direct Investment, 1997-2005 (in percent of GDP)

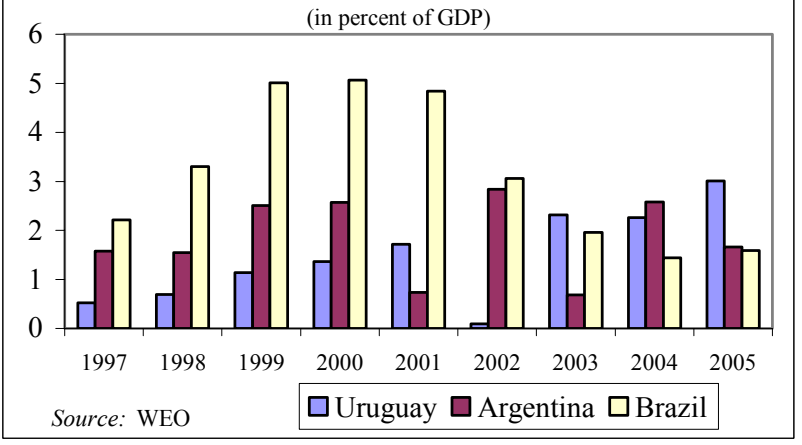




\section{Competitiveness Indicators}

7. Although the ratio of tradable to non-tradable goods prices has declined since the crisis, it remains substantially above pre-crisis levels (Figure 6). This ratio, derived from the components of the consumer price index, can be interpreted as an indicator of internal competitiveness between the tradable and non-tradable sectors. Sometimes referred to as the internal exchange rate, an increase in this ratio points to a rise in relative competitiveness of the tradable sector. After having increased markedly with the 2002 devaluation, the ratio has been on a declining trend, and by February 2006, it had returned to 1998/99 levels. Nonetheless, by this measure, the relative attractiveness of the tradable sector remains substantially above the levels observed before the crisis.

\section{Proxies for profit margins of the} tradable sector underscore its continued attractiveness. Figure 7 shows the ratio of export unit values to wages and unit labor costs (ULC). Relative to wages, export prices have been declining since 2004, but have remained above pre-crisis levels. Factoring in productivity increases, the ratio of export prices to ULC is a somewhat closer proxy for profit margins in the export sector. This ratio has improved more during the crisis and fallen by less since, remaining more than 80 percent above its pre-crisis level in 2001.
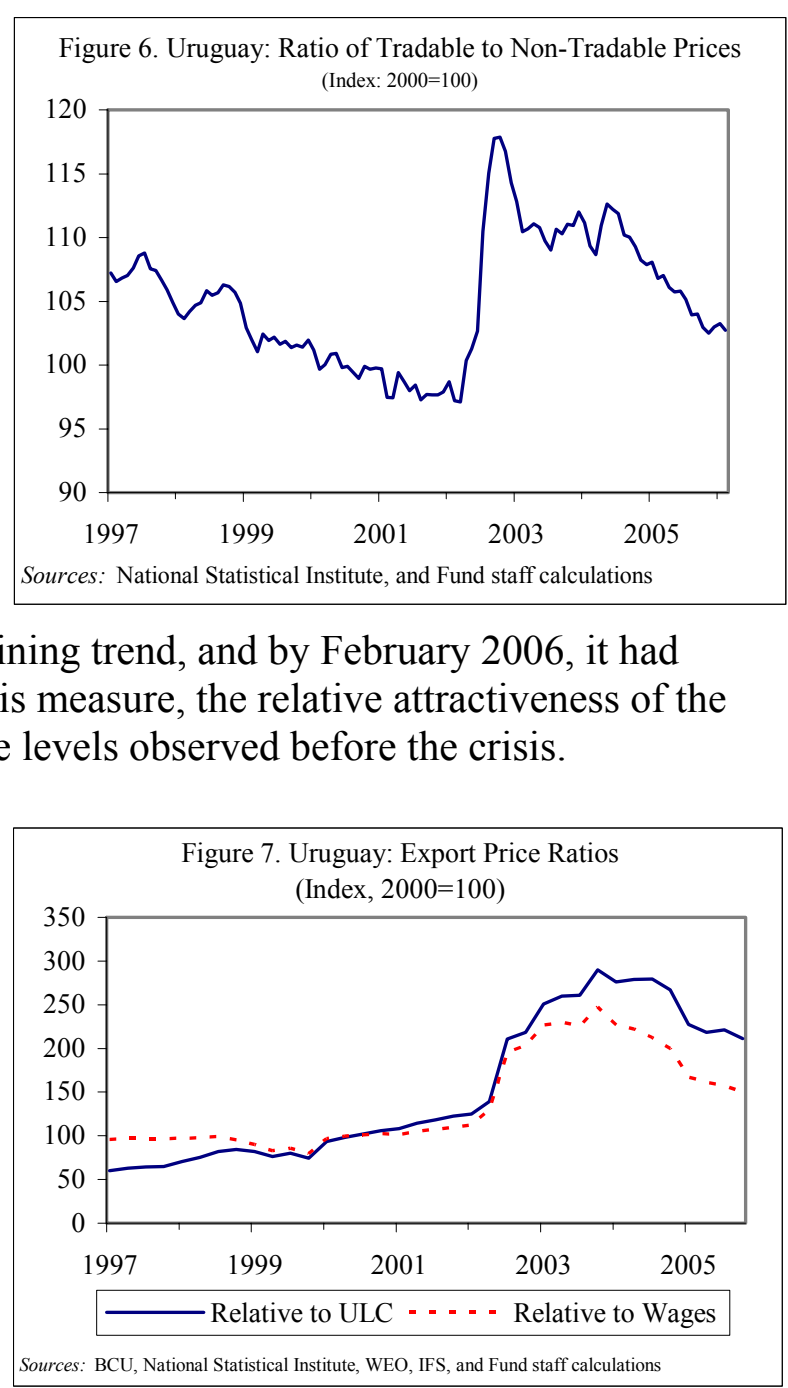

9. Bilateral real exchange rates (RER) with respect to major trading partners have shown markedly differing developments (Figure 8). The RER with respect to Argentina appreciated strongly in late 2001 when the Argentine peso devalued, but a pick-up in Argentina's inflation rate and subsequently the devaluation of the Uruguayan peso quickly reversed a large share of that appreciation. Since 2003, the bilateral RER has been appreciating again, largely reflecting the nominal appreciation of the Uruguayan peso at a time when the Argentine currency did not appreciate much. By contrast, the RER with respect to Brazil has been depreciating since 2002, reflecting in part Uruguay's devaluation and, more recently, the strength of the Brazilian real. The RERs with respect to the U.S. and 
Figure 8. Real Exchange Rate Relative to Selected Trading Partners, 1997-2005 (Index, 2000=100)
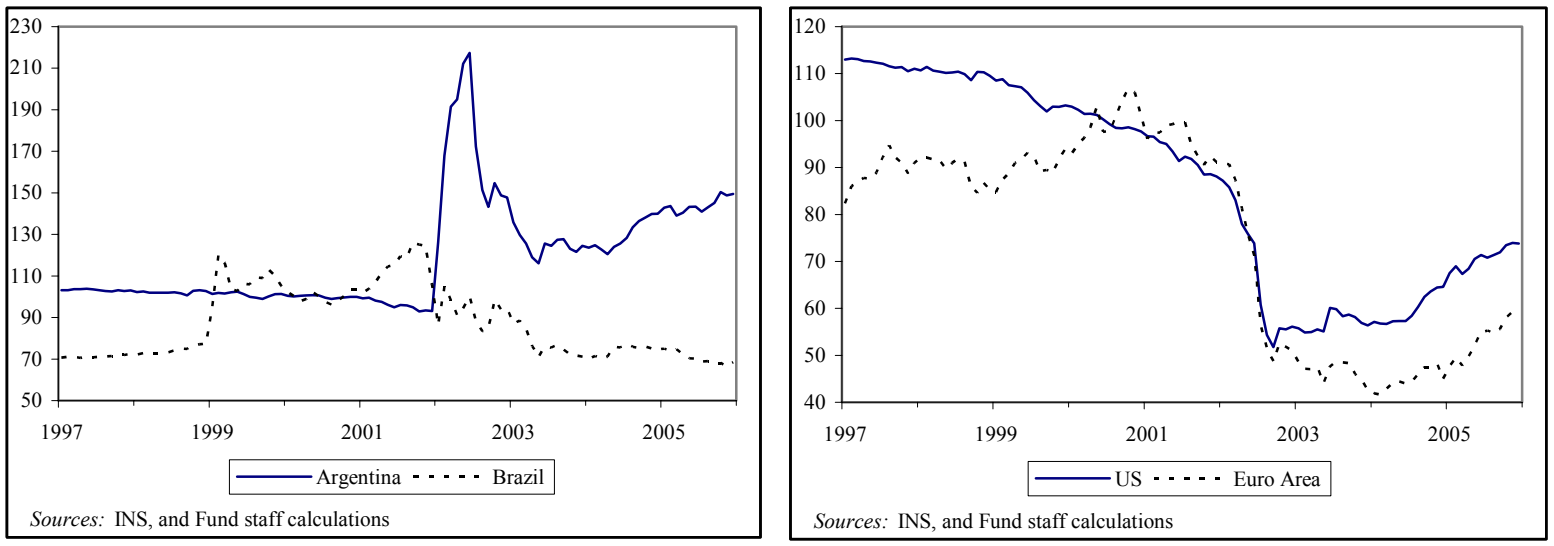

the Euro area have depreciated through the crisis period, and have only partially recovered since.

10. The value of the peso appears broadly in line with differences in productivity. Figure 9 plots per-capita income levels - as a proxy for productivity in the tradable sectoragainst the ratio of market exchange rates to estimated PPP exchange rates for selected Latin American countries, and a regression line based on a cross section of 180 countries. The upward-sloping regression line reflects the notion that a country's real exchange rate tends to appreciate as its productivity increases. Higher productivity in the tradable sector tends to induce an increase in tradable sector wages, and as wages equalize across sectors, this would induce higher prices for non-tradable goods and thus an increase in consumer prices relative to trading partners - and hence a real appreciation (Balassa-Samuelson effect). Countries above (below) the regression line could be interpreted to have a relatively more appreciated (depreciated) RER than explained by differences in productivity, proxied in the chart by percapita income. By this measure, Uruguay's RER appears broadly adequate: having depreciated substantially during the 2002 crisis, Uruguay's exchange rate has recovered in 2004-05 to close to the regression line. 


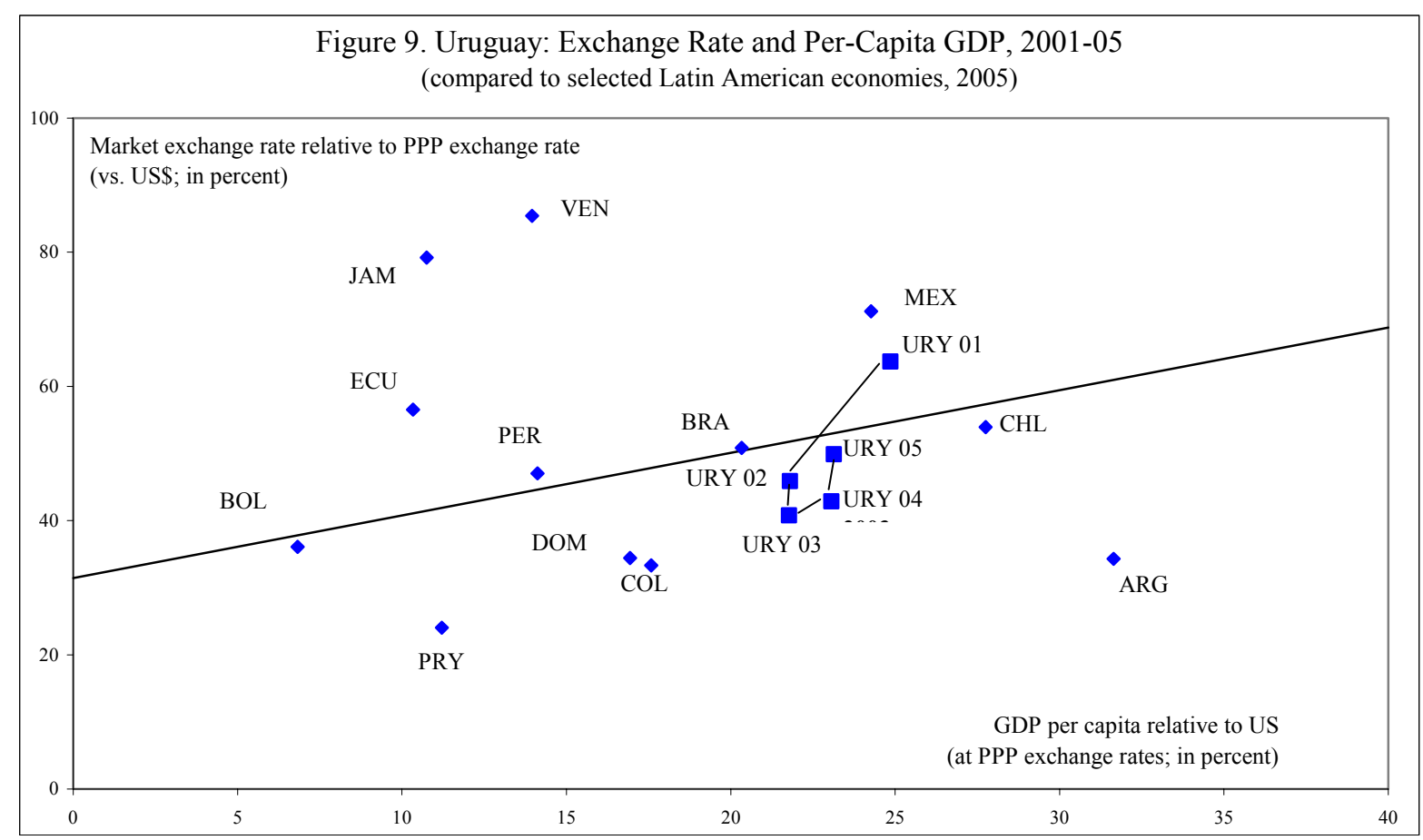

11. The trade-weighted CPI-based REER remains around 20 percent below its pre-crisis level (Figure 10). After relative stability in the late 1980 s and a long period of real appreciation throughout the 1990s, the REER depreciated by some 35 percent in 2002, and has since recovered to around 80 percent of its 2001 level.

\section{The PPI and ULC-based REER measures also support the notion that Uruguay has remained competitive}

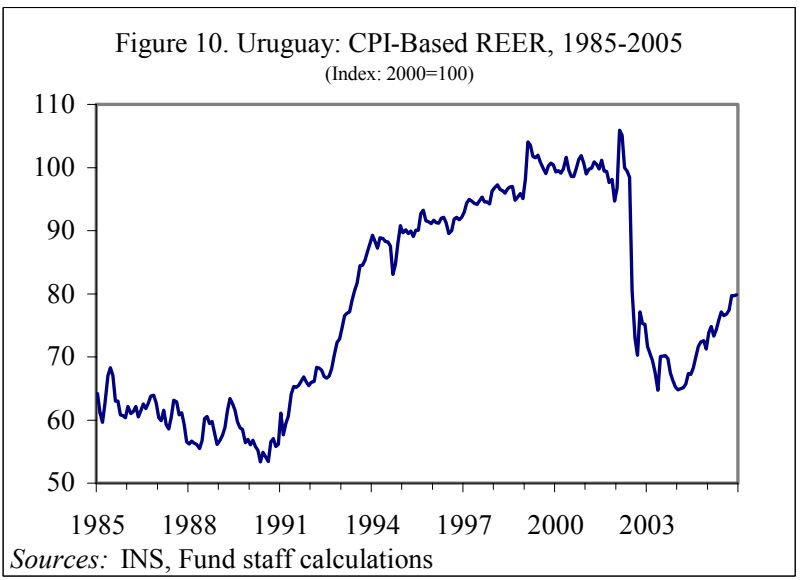

(Figure 11). Given the higher share of tradable goods in the PPI than in the CPI, the PPIbased REER has shown less variability in the face of nominal exchange rate movements. Nonetheless, it underwent similar trends as the CPI-based variant and remains more than 10 percent below pre-crisis levels. As an indicator of cost competitiveness, the ULC-based REER, which can be interpreted as an indicator of relative profitability in the production of traded goods in the domestic economy vis-à-vis trading partners, remains around 43 percent more depreciated than its pre-crisis level in 2001. 


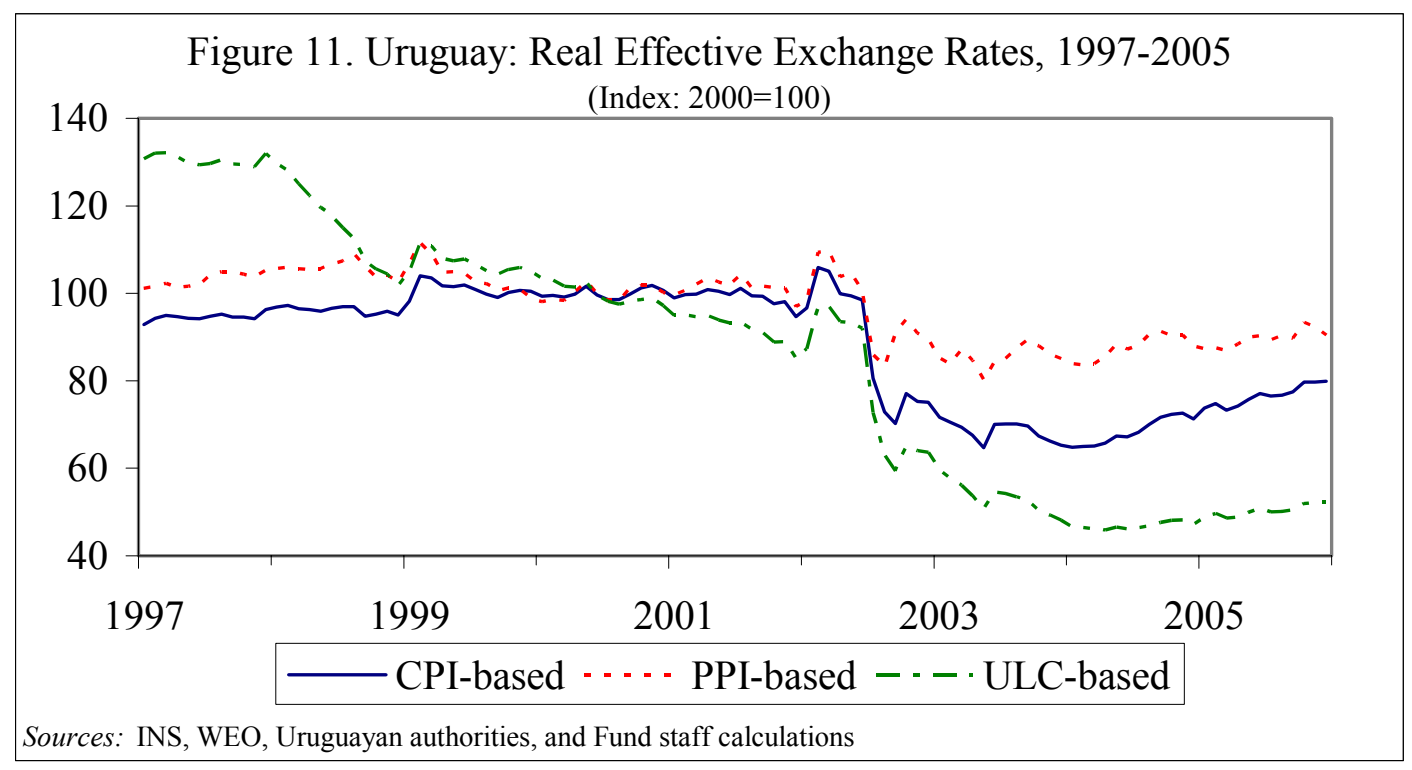

\section{Estimating an Equilibrium REER}

13. The estimation of an equilibrium REER can shed light on whether the REER is currently misaligned. Among the large body of literature on the estimation of equilibrium REERs, a recent strand follows the "adjusted PPP" approach, relating the dynamics of REERs to a set of underlying economic fundamentals, typically including measurements for productivity differentials, the openness to trade, the external financial position, and other variables (see, for example, Bayoumi and others. (2005)).

14. The dataset consists of a number of commonly considered potential determinants of the equilibrium real exchange rate, using quarterly data from 1988-2005:

- $\quad$ Per capita real GDP relative to trading partners (RGDP). This variable is calculated as Uruguay's real per capita GDP divided by a trade-weighted basket of per capita real GDP of Uruguay's trading partners. It is a proxy for productivity differentials in the traded sector between Uruguay and its trading partners, intended to capture the Balassa-Samuelson effect. An increase in this variable would be expected to be positively correlated with increases (i.e., an appreciation) in the REER.

- Manufacturing output relative to trading partners (MANOP). Calculated as the ratio of Uruguay's manufacturing output relative to a trade-weighted basket of manufacturing output in Uruguay's trading partner countries, this variable proxies the relative supply of traded goods. Assuming imperfect substitutability between traded goods produced in different countries, an increase in domestic manufacturing output relative to trading partners would tend to reduce the domestic price of manufactured products, likely weighing more on the domestic CPI than on trading partners' CPIs. An increase in relative manufacturing output would thus be expected to be associated with a declining REER. 
- $\quad$ Fiscal balance as percent of GDP (FIS). An improvement in the fiscal balance would normally be associated with a decline in domestic demand. To the extent that the decline in spending affects non-tradable goods, their prices, and thus also the REER, would be expected to decline.

- $\quad$ Terms of trade (TOT). An increase in the terms of trade would normally be associated with an increase in the REER, given wealth effects on domestic demand.

- Openness (OPEN). Calculated as the ratio of the sum of exports and imports to GDP, increased openness would tend to be associated with a more depreciated REER. As restrictive trade policies tend to increase the domestic price of traded goods, their removal would likely induce a decline in the domestic price level and thus in the REER.

- $\quad$ Ratio of net foreign assets to exports (NFA). Net debtor countries would need a more depreciated REER to generate the necessary trade surpluses to service their external obligations. Decreases in NFA would therefore tend to be associated with a decreasing REER.

- $\quad$ Real interest differential (RIDA). The difference between real interest rates in the domestic economy and its trading partners is expected to be positively correlated with the REER. An increase in real interest rates can reflect an increase in aggregate demand, increases in the productivity of capital, or tight monetary policy, all of which would tend to be associated with an appreciating REER.

Table 1. ADF unit root tests

\section{Unit root tests point to the non- stationarity of all variables (Table 1). ADF} tests support the notion of first-order integration at the 5 percent level for all variables except for OPEN and RIDA, which appear I(2). A prefix L indicates that the variable is expressed in logs. All variables (except for REER) enter as 8-quarter moving averages, attempting to smooth out short-term fluctuations that would distort an estimation of the equilibrium REER.

\begin{tabular}{lrrrrr}
\hline & \multicolumn{2}{c}{ Level } & & \multicolumn{2}{c}{ First difference } \\
\cline { 2 - 3 } \cline { 5 - 6 } & $\mathrm{t}$ statistic & $\mathrm{p}$-value/ & & $\mathrm{t}$ statistic & $\mathrm{p}$-value/1 \\
\hline LREER & 0.6840 & 0.8612 & & -7.4549 & 0.0000 \\
LRGDP & -0.3193 & 0.5671 & & -2.1325 & 0.0326 \\
LMANOP & 1.1655 & 0.9360 & -3.4659 & 0.0007 \\
FIS & -0.7563 & 0.3853 & -3.4256 & 0.0009 \\
TOT & -1.5302 & 0.1174 & -4.1804 & 0.0001 \\
OPEN & 0.6862 & 0.8617 & & -0.8158 & 0.3592 \\
NFA & -1.4252 & 0.1425 & -2.2881 & 0.0223 \\
RIDA & -3.0965 & 0.1150 & -3.2590 & 0.0815 \\
& & & & & \\
\hline
\end{tabular}

1/ MacKinnon (1996) one-sided p-values 
16. Estimating a vector error correction model (VECM), a co-integrating relation is found between the real effective exchange rate, real GDP relative to trading partners and net foreign assets. The existence of one cointegrating relation between these variables is confirmed by the Trace and Maximum Eigenvalue tests at the 5 percent level. The variables in the estimated long-run co-integrating relationship show the expected signs (Table 2). In particular, an increase in relative real per capita GDP by 1 percent is associated with a real appreciation of 2.4 percent, and an increase in net foreign assets of 1 percent of exports is associated with a real appreciation of 2 percent. Moreover, 37 percent of the deviation of the REER from its estimated long-run relation is eliminated within one quarter, suggesting that, in the absence of further shocks, Table 2. Selected VECM Results half of the gap would be closed within about $4 \frac{1}{2}$ months.

\begin{tabular}{lrr}
\hline & Coefficient & t-statistic \\
\hline \multicolumn{2}{l}{ Cointegrating Relationship } \\
LREER (-1) & 1.0000 & $\ldots$ \\
LRGDP (-1) & -2.4304 & -7.7699 \\
NFA (-1) & -0.0198 & -1.6301 \\
Trend & -0.0069 & -4.5049 \\
Const. & 4.0926 & $\ldots$ \\
Estimated Speed of Adjustment & \\
CointEq1 & -0.3655 & -3.6602 \\
Lag Structure & 3 & \\
\hline
\end{tabular}

17. The estimated equilibrium relation suggests that the REER is not overvalued. Figure 12 plots the estimated equilibrium rate and an estimated 95 percent confidence interval. Relative to the estimated equilibrium relation, Uruguay's REER was fairly well aligned throughout much of the 1990s. From late 2000 until the crisis, the REER was then increasingly overvalued, as the exchange rate regime prevented the REER from depreciating while the equilibrium rate, induced by the recession, declined markedly. With the floating of the exchange rate in mid-2002, the REER returned close to equilibrium. At end-2005, the REER was slightly below equilibrium, but within the estimated 95 percent confidence interval.

18. Taken in isolation, these results do not lend themselves to an overly firm interpretation, but jointly with other indicators they suggest that the exchange rate of the peso is not an issue for competitiveness. The presented exercise has merely demonstrated that the REER is currently slightly, but not significantly, below an estimate of the equilibrium REER, which is based on the average historical responsiveness to changes in relative real per capita GDP and NFA. Nevertheless, in conjunction with other evidence studied in previous sections, this exercise has lent further support to the hypothesis that Uruguay does currently not have a competitiveness problem. 


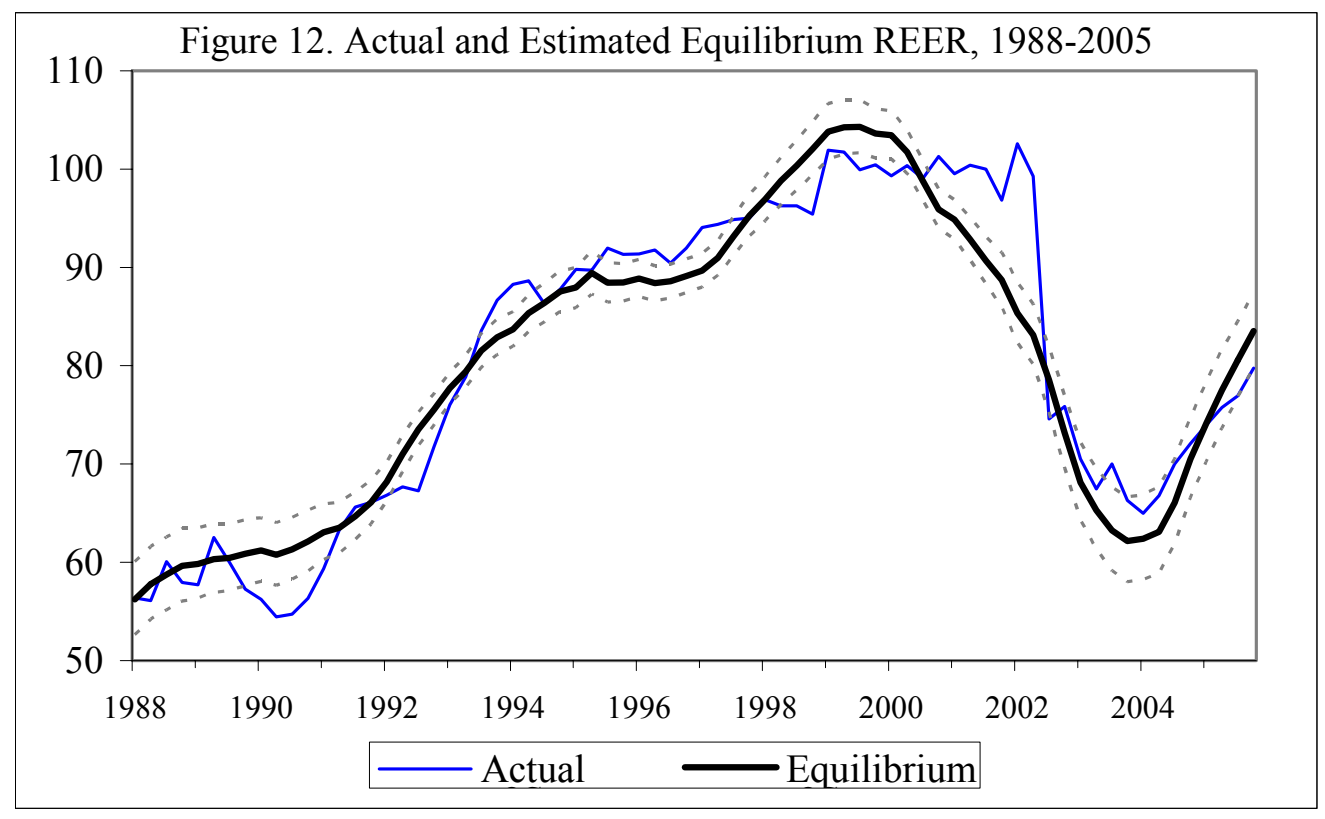

E. International Competitiveness Rankings

19. This section presents Uruguay's placement in international competitiveness rankings based on a variety of data and surveys. While the analysis presented so far has been based on an assessment of macroeconomic and financial data, the World Economic Forum's (WEF) World Competitiveness Indicators and the World Bank's Cost of Doing Business rankings used in this section focus on competitiveness from a structural angle, including institutional and business environment considerations.

20. Uruguay takes a midfield position in the WEF's survey. Out of 117 countries covered in the survey, Uruguay ranks at position 54 (with 1 indicating the highest ranking) for growth competitiveness (Argentina: 72; Brazil: 65) and at 70 for its business competitiveness (Argentina: 64; Brazil: 49). Uruguay fares relatively well regarding its technology infrastructure (PCs, internet hosts and telephone lines), enrolment in tertiary education, low levels of organized crime, good judicial independence and low favoritism in decisions of government officials. However, macroeconomic environment factors weigh on that result, including the still high level of government debt, low credit ratings and limited access to credit. Similarly, some technology-related factors lower the ratings for Uruguay, including low company spending on research and development, and the low number of utility patents. Survey participants named as the most problematic factors for doing business in Uruguay the access to financing, inefficient government bureaucracy, tax rates and regulations, policy instability, restrictive labor regulations, and inadequate supply of infrastructure.

21. The World Bank's "Doing Business in 2006" ranking for Uruguay is similar. Out of 155 countries, Uruguay ranks at position 85 for its ease of doing business (Argentina: 77; Brazil: 119). Uruguay ranks relatively favorable regarding the ease of hiring and firing 
workers and the ease of shareholder suits. However, factors weighing on the survey result include the relatively high effective profit taxes and cumbersome tax procedures, complex and time-consuming procedures for starting a business, registering property and enforcing contracts, and a low recovery rate in bankruptcy cases.

22. Many of the shortcomings identified in these surveys have already started to be addressed. The macroeconomic environment is being stabilized and debt levels are being reduced. Profit taxes are being simplified and reduced in the context of the tax reform. Spending on infrastructure is being gradually expanded in the current 5-year budget. Inefficiencies in bankruptcy procedures are being addressed in the context of the reform of the bankruptcy code. While a promising start has thus been made, it will be important to continue these efforts in order to further improve Uruguay's competitiveness from the institutional and business environment angle.

\section{F. Conclusions}

23. Most indicators suggest that Uruguay remains competitive. Uruguay's external performance has remained solid and ratios of tradable to non-tradable prices and of export prices to ULC point to the continued attractiveness of Uruguay's traded sector. The REER based on CPI (ULC) has remained some 20 (43) percent more depreciated than before the crisis. Moreover, the real exchange rate appears to be roughly in line with other countries after accounting for productivity differentials. A quantitative estimate of the equilibrium REER has lent further support to the impression that Uruguay does not have a competitiveness problem.

24. However, some indicators point to a trend of somewhat deteriorating competitiveness, and international competitiveness rankings show room for

improvement. While still better than before the crisis, a number of indicators have entered a slowly deteriorating trend, including notably the ratio of tradable to non-tradable prices. It will thus be necessary to continue monitoring closely future developments in competitiveness. Moreover, structural factors constraining competitiveness, as identified, for example, in the recent WEF and World Bank rankings, should continue to be addressed. 


\section{References}

Bayoumi, Tamin, Hamid Faruqee, and Jaewoo Lee, 2005, “A Fair Exchange? Theory and Practice of Calculating Equilibrium Exchange Rates," IMF Working Paper 05/229 (Washington: International Monetary Fund).

Dunaway, Steven, and Xiangming Li, 2005, “Estimating China's 'Equilibrium' Real Exchange Rate,” IMF Working Paper 05/202 (Washington: International Monetary Fund).

Dufrenot, Gilles J., and Etienne B. Yehoue, 2005, "Real Exchange Rate Misalignment: A Panel Co-Integration and Common Factor Analysis," IMF Working Paper 05/164 (Washington: International Monetary Fund).

Fernández, Adrián, Mariana Ferreira, Paula Garda, Bibiana Lanzilotta, and Rafael Mantero, 2005, “TCR ‘Competitivo’ Y Otras Soluciones Desajustadas,” Centro De Investigaciones Económicas (CINVE), mimeo.

Isard, Peter, and Hamid Faruqee, 1998, Exchange Rate Assessment-Extensions of the Macroeconomic Balance Approach, IMF Occasional Paper No.167 (Washington: International Monetary Fund).

Isard, Peter, Hamid Faruqee, G. Russell Kincaid, and Martin Fetherston, 2001, Methodology for Current Account and Exchange Rate Assessments, IMF Occasional Paper No. 209 (Washington: International Monetary Fund).

Lipschitz, Leslie, and Donogh McDonald, 1991, "Real Exchange Rates and Competitiveness: A Clarification of Concepts, and Some Measurements for Europe," IMF Working Paper 91/25 (Washington: International Monetary Fund).

MacDonald, Ronald, and Luca Ricci, 2003, "Estimation of the Equilibrium Real Exchange Rate for South Africa," IMF Working Paper 03/44 (Washington: International Monetary Fund).

World Bank, 2006, “Doing Business in 2006-Creating Jobs,” (Washington: The World Bank).

World Economic Forum, 2005, “The Global Competitiveness Report 2005-2006-Policies Underpinning Rising Prosperity” (New York: Palgrave Macmillan). 


\section{Post-Crisis Credit: Facts, Lessons, and Prospects ${ }^{4}$}

\section{A. Introduction}

1. Since its sharp contraction around the $\mathbf{2 0 0 2}$ crisis, bank credit to the private sector has remained low, possibly posing a problem for medium-term growth. The fall has been of about 60 percent in real terms. While post-crisis recoveries often happen with virtually no resumption in credit (see Calvo, Izquierdo, and Tanzi, 2006), a lasting lack of financial intermediation could pose an obstacle to medium-term growth. A growing body of evidence suggests that financial intermediation not only correlates with, but also causes growth (see, for example, Levine, 2004).

2. This paper explores the evolution of credit, drawing lessons from other countries to assess likely prospects for economic activity and its financing. Specifically, the paper asks the following questions: How has bank credit, and to the extent measurable, other sources of financing evolved since the crisis? What are the reasons behind this behavior? Has there been a credit crunch? How does Uruguay's experience compare with that of other countries suffering banking crises? What do these developments imply for investment and output? What policy lessons can we learn from other countries?

3. The low credit flows reflect both supply and demand factors, and the evidence does not suggest the prevalence of credit rationing. On the supply side, banks have been subject to stricter prudential rules. Most foreign-owned institutions have become risk-averse after the crisis. Banks have been reluctant to lend to indebted borrowers and their lending capacity has decreased with the fall in overall deposits and the rise in the share of short-term deposits. On the demand side, some companies may have been postponing investments in the face of large spare capacity. An econometric approach using a disequilibrium framework suggests that since 2003, demand has constrained credit growth, but the results should be interpreted with caution given data and specification difficulties.

4. Peso credit is rising. The dollarization of credit is falling: while new peso credit flows are positive, dollar-denominated credit is declining. Credit dollarization has fallen more strongly in the nontradable sector, reducing vulnerabilities.

5. The present lack of credit should not endanger the continuation of the recovery. International experience shows that after banking and currency crises, companies typically find other sources of finance. Credit then picks up gradually after about three years. In Uruguay, the economic recovery is likely to continue despite the current low lending levels for several reasons. First, alternative sources of credit are helping, at least in part, to finance the recovery. In retrospect, domestic bank credit has not been the only source of finance for Uruguayan economic activity. Moreover, the impact of the drop in bank lending on activity may not be as severe as in other countries, as industries that typically depend heavily on financing do not explain a large fraction of output in Uruguay. Second, in contrast to the

\footnotetext{
${ }^{4}$ Prepared by Jorge Iván Canales-Kriljenko and Gastón Gelos.
} 
post-crisis experience of some other countries, where undercapitalized banks were unable to lend, banks in Uruguay are well capitalized, with the exception of housing bank BHU.

6. Further institutional reforms and the use of trust funds could help in facilitating access to finance. Further strengthening of the financial system would consolidate confidence, yielding an increase in the maturity of deposits. Improving the credit registry, bankruptcy procedures, and corporate transparency could help improve the credit culture and ultimately financial intermediation. More developed short-term money markets could help banks reduce their liquidity holdings and lend. Dedollarization and the development of hedging instruments would reduce currency mismatches, allowing banks to lend with lower credit risk. Trust funds (fideicomisos) could be useful financing instruments while balance sheets are still recovering.

\section{B. Evolution of Credit to the Private Sector}

7. After falling for three years, credit stocks have now stabilized. Bank credit to the private sector has dropped by 60 percent in real terms from its peak in 2001, and has only recently stopped falling. ${ }^{5}$

8. New credit flows are slowly recovering but remain significantly below precrisis levels. They have displayed a slightly positive trend in real terms since 2003, growing about 4 percent a year, but are still only about half their 2001 levels.

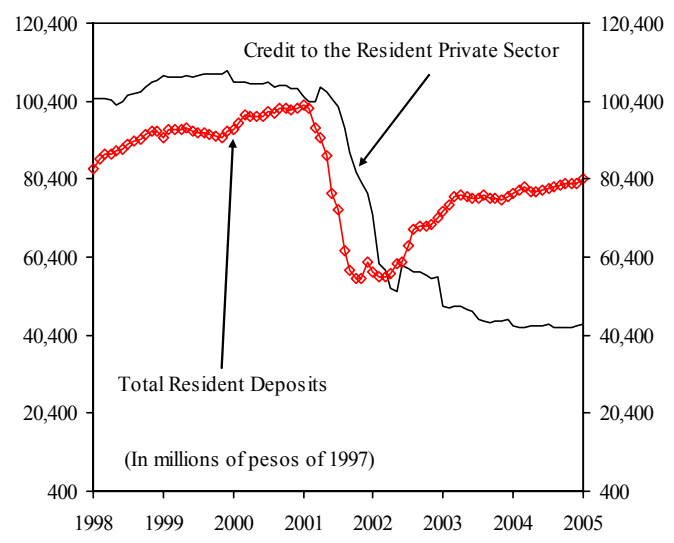

\section{After increasing sharply during the crisis, nonperforming-loan ratios (NPL)} have fallen significantly. The NPL ratio has dropped from 60 percent in 2002 to 18 percent in 2005. Excluding BHU, which no longer conducts financial intermediation, NPLs have fallen to less than 5 percent from a crisis peak of "only" 25 percent (Figure 1). This reflects mainly (i) an improvement of economic conditions and ensuing collection of provisioned loans, but also (ii) the carving out of the bad loan portfolio from the banking system through restructuring of private and public banks and (iii) a government guarantee on

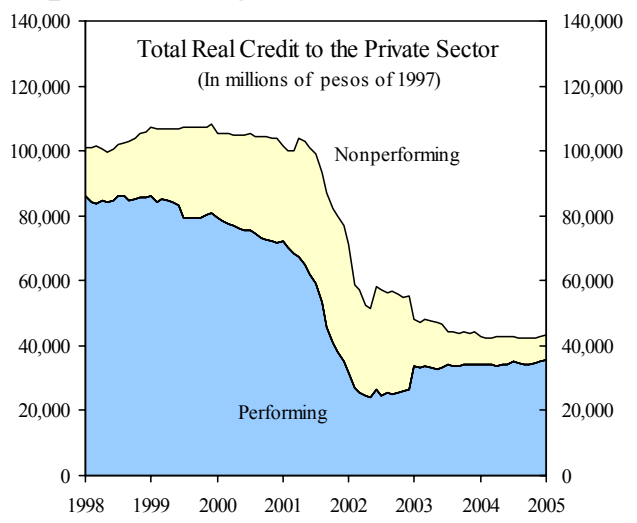
assets in BROU's balance sheet backed with nonperforming loans allowing BROU to classify them as performing.

\footnotetext{
${ }^{5}$ The graph shows gross credit, without correcting for loan writeoffs, at exchange rates with a constant purchasing value of the dollar. The picture is similar with gross credit at current exchange rates, but with a pronounced spike in 2002 reflecting the sharp peso depreciation during the crisis.
} 
10. Dollarization of credit is falling, reducing vulnerabilities somewhat. Pesodenominated lending increased by about 14 percent in real terms in 2005 , helping bring down the degree of dollarization of credit from 83 percent in 2002 to 69 percent in December 2005 (part of this reduction also reflects peso appreciation). The dollarization of new loans has also followed a similar trend. Excluding BHU, whose stock of loans is indexed to wages, the degree of dollarization has reverted to its precrisis average level of 80 percent. Credit dollarization has fallen more strongly in the nontradable sector, reducing currency mismatches between revenues and costs. The fraction of foreign-currency debt in the construction sector, for example, has fallen from 96 percent in 2002 to 81 percent in 2005 , and in commerce, it has dropped from 97 percent to 87 percent. This is due to increases in peso credit as well as a fall in dollar loans.

\section{Trade and "other" sources of} nonbank credit have become somewhat more important as a source of financing for small firms. The share of trade credit in total debt rose from 17 percent to 22 percent for small companies, and the share of "other" credit (which encompasses debt with private individuals, the government, payables due, provisions, unpaid dividends and early receipts) rose from 43 to 57 percent (Table 1). For medium-sized and large companies, the share of trade credit in total debt fell and the share of "other" credit rose only

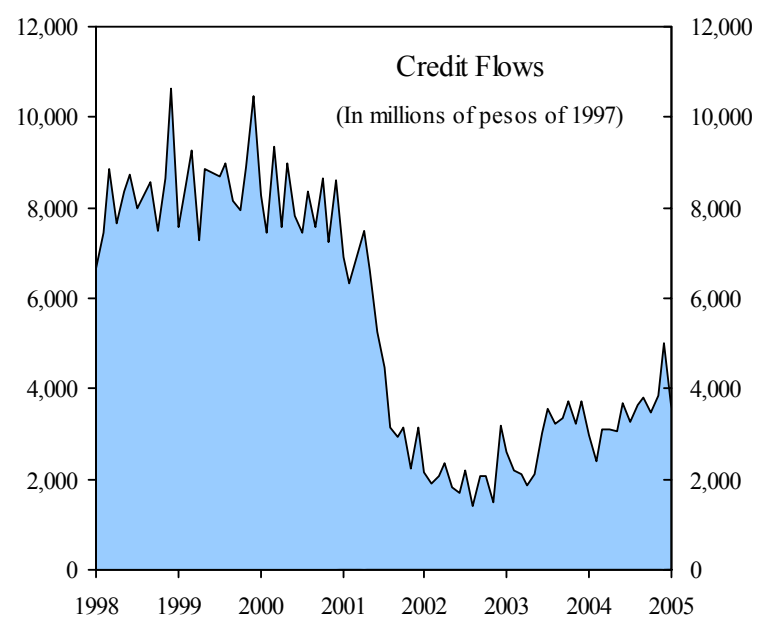
mildly.

12. Repatriated capital has likely helped in financing the recovery. Deposits that left the financial system during the 2002 crisis have not returned, remaining as deposits in BIS reporting banks. These deposits, which rose from US\$3.6bn prior to the crisis to US $\$ 4.5$ billion in the second quarter of 2002, kept increasing since then; they could have been used to finance the import of intermediate products and other working capital. However, loans from BIS reporting banks have fallen from US\$1.9 billion in early 2002 to about US\$1.2 billion in late 2005. Nevertheless, balance of payments data, including the sizeable change in errors and omissions, suggest the return of capital that had fled the domestic financial system, and was partly held "under the mattress." These funds are likely to have been partly used, without being intermediated through the banking system, to finance consumption and investment. 


\section{Financial Structure Indicators of the Corporate Sector in Uruguay: 2001, 2003 and 2004 1/}

(In percent)

\begin{tabular}{|c|c|c|c|c|}
\hline INDICATOR & SIZE & 2001 & 2003 & 2004 \\
\hline \multirow[t]{3}{*}{ Debt to Sales } & Big & 39 & 34 & 37 \\
\hline & Medium & 41 & 31 & 46 \\
\hline & Small & 135 & 85 & 33 \\
\hline \multirow{3}{*}{$\begin{array}{l}\text { Financial Debt } \\
\text { to Total Debt }\end{array}$} & Big & 34 & 33 & 39 \\
\hline & Medium & 30 & 29 & 29 \\
\hline & Small & 40 & 16 & 21 \\
\hline \multirow{3}{*}{$\begin{array}{l}\text { Trade Credit } \\
\text { to Total Debt }\end{array}$} & Big & 42 & 36 & 32 \\
\hline & Medium & 38 & 40 & 34 \\
\hline & Small & 17 & 16 & 22 \\
\hline \multirow{3}{*}{$\begin{array}{l}\text { Short Term Debt } \\
\text { to Total Debt }\end{array}$} & Big & 99 & 100 & 100 \\
\hline & Medium & 100 & 100 & 100 \\
\hline & Small & 100 & 100 & 100 \\
\hline \multirow{3}{*}{$\begin{array}{l}\text { Foreign Currency Debt } \\
\text { to Total Debt }\end{array}$} & Big & 65 & 76 & 56 \\
\hline & Medium & 74 & 78 & 59 \\
\hline & Small & 77 & 48 & 8 \\
\hline \multicolumn{2}{|l|}{ Number of Observations } & 500 & 696 & 408 \\
\hline
\end{tabular}

\section{Has There Been a Credit Crunch?}

13. Does a low demand for credit or a limited credit supply explain the low bank credit? To explore this issue, we examine whether demand has exceeded supply at prevailing interest rates. First, we briefly discuss institutional and economic factors that may have contributed to a fall in demand and supply. Next, we explore this question more formally.

\section{Institutional and economic factors}

\section{On the supply side, banks have been reluctant or restricted to lend:}

- Deposits have fallen slightly. Resident deposits have fallen only mildly since the crisis, with the 20 percent drop in its dollar value offset by a similar real depreciation of the peso over the period.

- The maturities of deposits have shortened. The share of sight in total nonfinancial private sector deposits has increased from about 30 percent in 2001 to about 65 percent in early 2006, partly because depositors distrust time deposits that were reprogrammed during the crisis. Of course, to some extent this is an endogenous 
phenomenon, since banks could in principle offer higher rates to attract longer-term deposits. In addition, the maturity of time deposits was not high before the crisis.

- Banks have faced tighter prudential limits to lending. This applied in particular to public banks, which account for 60 percent of deposits. Since the crisis, the supervisor has forbidden BHU from lending until it complies with prudential rules. BROU and NBC have faced additional liquidity requirements. In general, both peso and dollar reserve requirement rates are now larger than in 2001, but peso rates declined since their peak in 2002. Yet, banks have continued to hold liquid assets exceeding reserve and liquidity requirements.

- $\quad$ Foreign-owned banks have been under tighter risk-management directives after the crisis. Many foreign banks adopted risk management systems and practices of their parent institutions and anecdotal evidence after the crisis suggests that many foreign-owned banks have become more risk averse.

- Creditworthy borrowers may still be scarce, and improved prudential regulation has raised the costs of lending to highly indebted borrowers. The rules require banks to classify corporations with nonperforming loans to any single bank as risky. After being hit by the crisis, private firms and households remain indebted, and corporations still have in their balance sheets liabilities to the liquidation funds for the failed banks. They also continue to register loans that banks have written off but remain as off-balance-sheet assets. Only small companies have reduced their indebtedness ratios substantially compared with pre-crisis levels (Table 1). While the debt-to-sales ratio of large firms has remained broadly constant, that of medium-sized firms has risen. Balances sheets now appear to be recovering, making firms gradually more attractive to lenders. ${ }^{6}$

- The closure of failed banks may have affected credit supply. Customers of closed institutions may have had difficulties getting credit from other banks.

15. The demand for new bank credit may also have been small, as companies' willingness to incur further debt has remained limited.

a. Output has only now returned to 1998 levels, implying that the demand for investment and credit may have been limited. Companies may have decided to exploit spare capacity, postponing investment decisions, as has happened in many post-crises recoveries.

b. After the crisis experience, potential borrowers are limiting leverage. Companies and households may not yet be willing to incur the risks of new debt, particularly in foreign currency.

\footnotetext{
${ }^{6}$ See Licandro (2006).
} 
16. Banking spreads have fallen, suggesting that bank competition has not

decreased. Banking spreads tend to rise with the level of interest rates, and rates levels have fallen both for dollar and in peso terms. Nevertheless, for U.S. dollars, deposit rates are close to levels seen in the pre-crisis period, while spreads are now much tighter. While this evidence is not enough to rule out credit rationing, it indicates that competitive pressures may have become stronger.
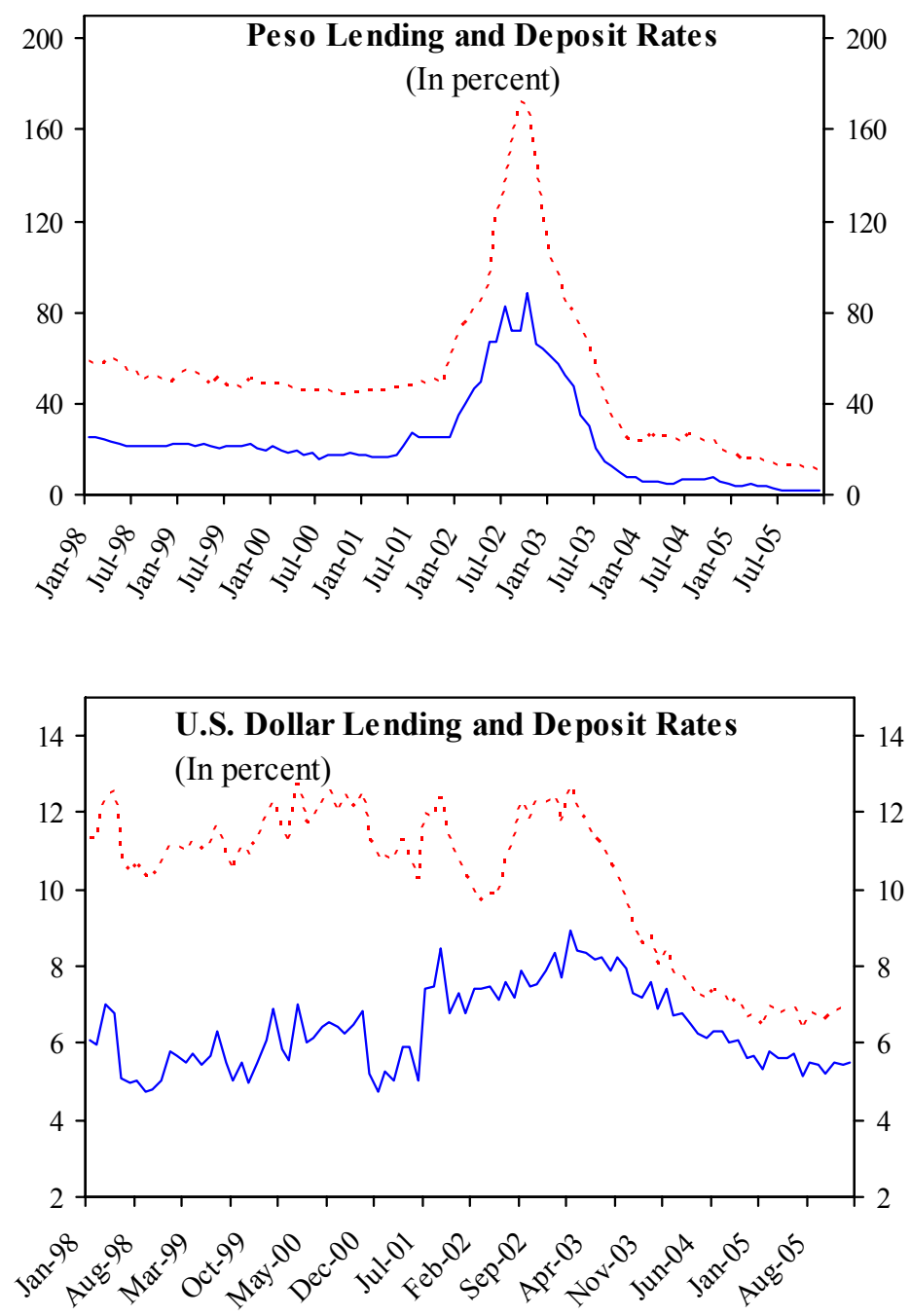

\section{An empirical disequilibrium framework}

17. This section examines more formally, using a disequilibrium model, the question of whether supply or demand for credit has been the binding constraint. In credit rationing models, such as Stiglitz and Weiss (1981), credit demand can exceed supply at prevailing interest rates because of adverse-selection effects. Banks prefer to ration credit rather than to increase interest rates since higher interest rates induce a selection toward riskier projects. One way to assess empirically whether credit rationinig occurs is the method 
by Kiefer (1980) and Maddala and Nelson (1974). ${ }^{7}$ The demand for bank credit $C_{t}^{D}$ need not be equal its supply $C_{t}^{S}$. The realization of credit is given by:

$$
C_{t}=\min \left(C_{t}^{S}, C_{t}^{D}\right)
$$

18. The supply of credit is modeled as a function of interest rates, the health of firms' balance sheets, lending capacity, and nonperforming loans. Following Ghosh and Ghosh (1999) and Barajas and Steiner (2002), the specification is as follows:

$C_{t}^{s}=\beta_{0}^{s}+\beta_{1}^{s}\left(r_{t}^{\text {lending }}-r_{t}^{\text {deposits }}\right)+\beta_{2}^{s} l_{t}+\beta_{3}^{s} N P L_{t-1}+\beta_{4}^{s} P R O V_{t-1}+\varepsilon_{t}^{s}$,

where:

- $\quad r_{t}^{\text {lending }}$ is the lending rate and $r_{t}^{\text {deposits }}$ is the deposit rate. Both dollar and peso spreads enter the supply function.

- $\quad y_{t}$ is current output (real GDP, seasonally adjusted), to proxy for the health of firms' balance sheets

- $\quad l_{t}$ : Commercial banks' real lending capacity (defined as the minimum of (i) total bank liabilities plus net worth minus required reserves and liquidity requirements minus equity capital, and (ii) the maximum possible loans permitted by the prevailing capital adequacy requirement and existing bank capital) measured at exchange rates with constant purchasing power.

- $\quad N P L_{t-1}$ the ratio of nonperforming loans to total loans in bank books

- $\quad P R O V_{t-1}$ the ratio of provisions to nonperforming loans

- and credit is measured as gross credit in the books of banks and cooperatives, at exchange rates with constant purchasing power, deflated by the CPI.

19. The demand for credit is assumed to depend on the real interest rate, expected future output, and macroeconomic conditions. Specifically :

$C_{t}^{d}=\beta_{0}^{d}+\beta_{1}^{d} r_{t}^{\text {lending }}+\beta_{2}^{d} y_{t}^{g a p}+\beta_{4}^{d} \Pi_{t}+\beta_{5}^{d} U B I_{t}+\varepsilon_{t}^{d}$

\footnotetext{
${ }^{7}$ For applications of this approach to the analysis of bank credit, see Laffont and García (1977), Sealey (1979), Pazarbasioglu (1997), Catão (1997), Ghosh and Ghosh (1999), and Barajas and Steiner (2002).
} 
where:

- $\quad r_{t}$ : the real lending rate (both for peso and dollar credit).

- $y_{t}^{\text {gap }}$ : the output gap, measured as the deviation of current industrial production from its (Hodrick-Prescott filtered) long-run trend, or, alternatively, the CERES leading indicator of economic activity.

- $\Pi_{t}$ : expected inflation (as an indicator of the general macroeconomic environment)

- $U B I_{t}$ : Country risk, as measured by the Uruguay Bond Index from República AFAP.

As argued in Ghosh and Ghosh (1999), the use of a Hodrick-Prescott filter to estimate trend output provides a simple measure of the output gap. The output gap enters as a proxy for the intuition that, in difficult times, firms may seek more credit. To avoid spurious swings in credit supply stemming from the sharp exchange-rate fluctuations in the sample, we convert foreign currency deposits and loans using an exchange rate that keeps purchasing power of a dollar constant within the sample period. Alternatively, we use a 12-month moving average of the nominal exchange rate to smooth the effect of exchange rate volatility. To allow for a differential behavior during the height of the crisis, in some estimation we include a dummy for this period. Estimation in levels is legitimate as long as the determinants of supply and credit demand form a cointegrating vector, which is true in the present case. Following the notation in Ghosh and Ghosh (1999), the probability that an observation is supplyconstrained is given by:

$\theta_{t}=\operatorname{Pr} o b\left(C_{t}^{D}>C_{t}^{S}\right)=\Phi\left(\left(C_{t}^{d}-C_{t}^{s}\right) /\left(\sigma^{s 2}+\sigma^{d 2}\right)\right)$

where $\sigma^{s 1}$ and $\sigma^{s 2}$ are the standard errors of the credit supply and demand functions and $\Phi(\bullet)$ is the cumulative normal distribution function. This can be used to derive the unconditional density function of $C_{t}$. Maximizing the corresponding likelihood function allows for the estimation of both supply and demand. 


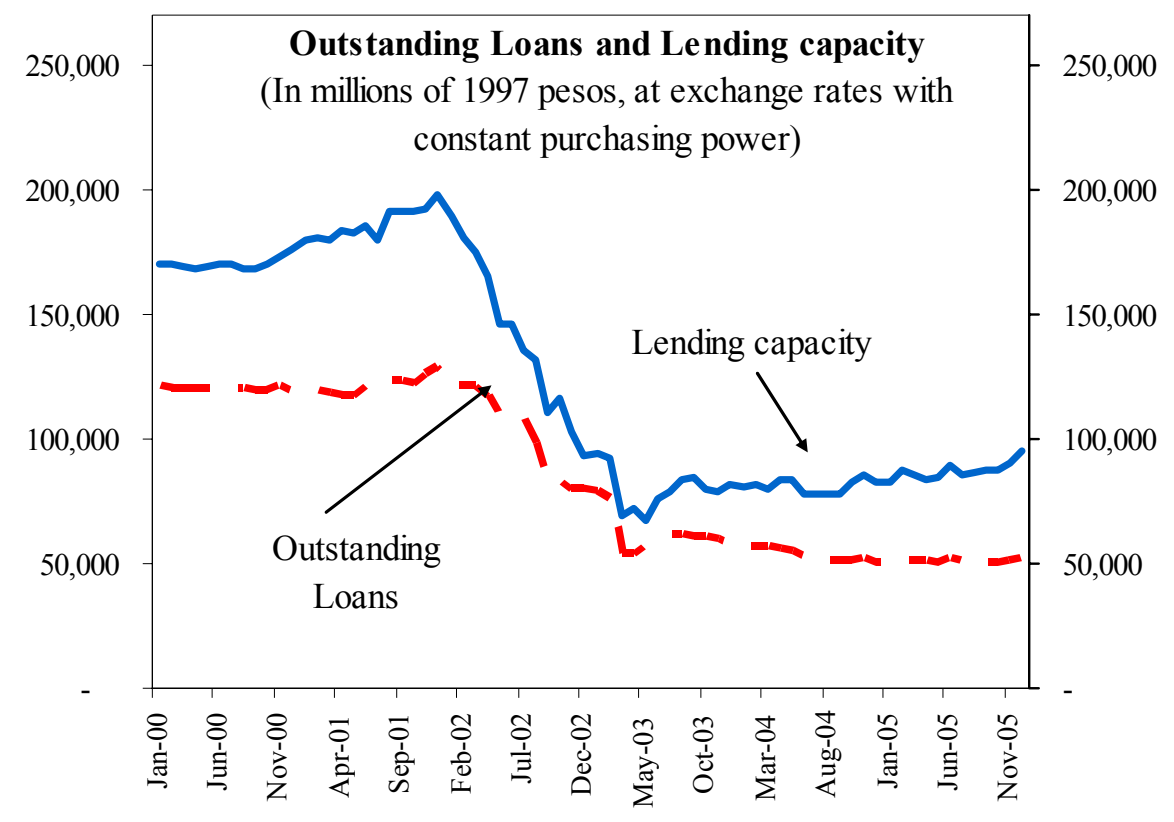

20. The evidence does not suggest that the decline in bank lending after the crisis reflects mainly a rationing phenomenon. As could be expected, lending capacity falls strongly during the crisis due to the difficulties faced by banks and the subsequent tightening of liquidity requirements and increase in demand for liquid assets. In 2003, lending capacity begins to recover, showing a steady and moderate increase, staying below pre-crisis levels and above actual observed loan stocks thereafter. The estimations indicate that since 2003, credit supply at prevailing interest rates has exceeded demand (see figure). ${ }^{8}$ While both demand and supply fall with the crisis, supply recovers more strongly, driven by the improvement in lending capacity. Details of the estimations can be found in the appendix. The results should be interpreted with caution given specification and data problems. Estimates of individual coefficients vary and the broad qualitative conclusion of the absence of credit rationing in the last 2-3 years appears to be robust to different sample sizes, but not to alternative specifications. ${ }^{9}$ The estimations were also conducted for peso and dollar credit separately, yielding a similar qualitative picture. The qualitative result also holds when the credit series are adjusted for loan writeoffs and the loan portfolio of the banks liquidated during the crisis (currently in the liquidation funds and under recovery by asset management firms).

\footnotetext{
${ }^{8}$ The goodness-of-fit can be gauged by how well the minimum of estimated demand and supply tracks actual credit.

${ }^{9}$ The conclusion does not hold when using current exchange rates, but, as argued earlier, the use of current exchange rate is likely to produce significant measurement errors. When using a 12-month moving average of the exchange rate, credit ends to be demand-constrained until around mid-2004, becoming supply constrained thereafter.
} 


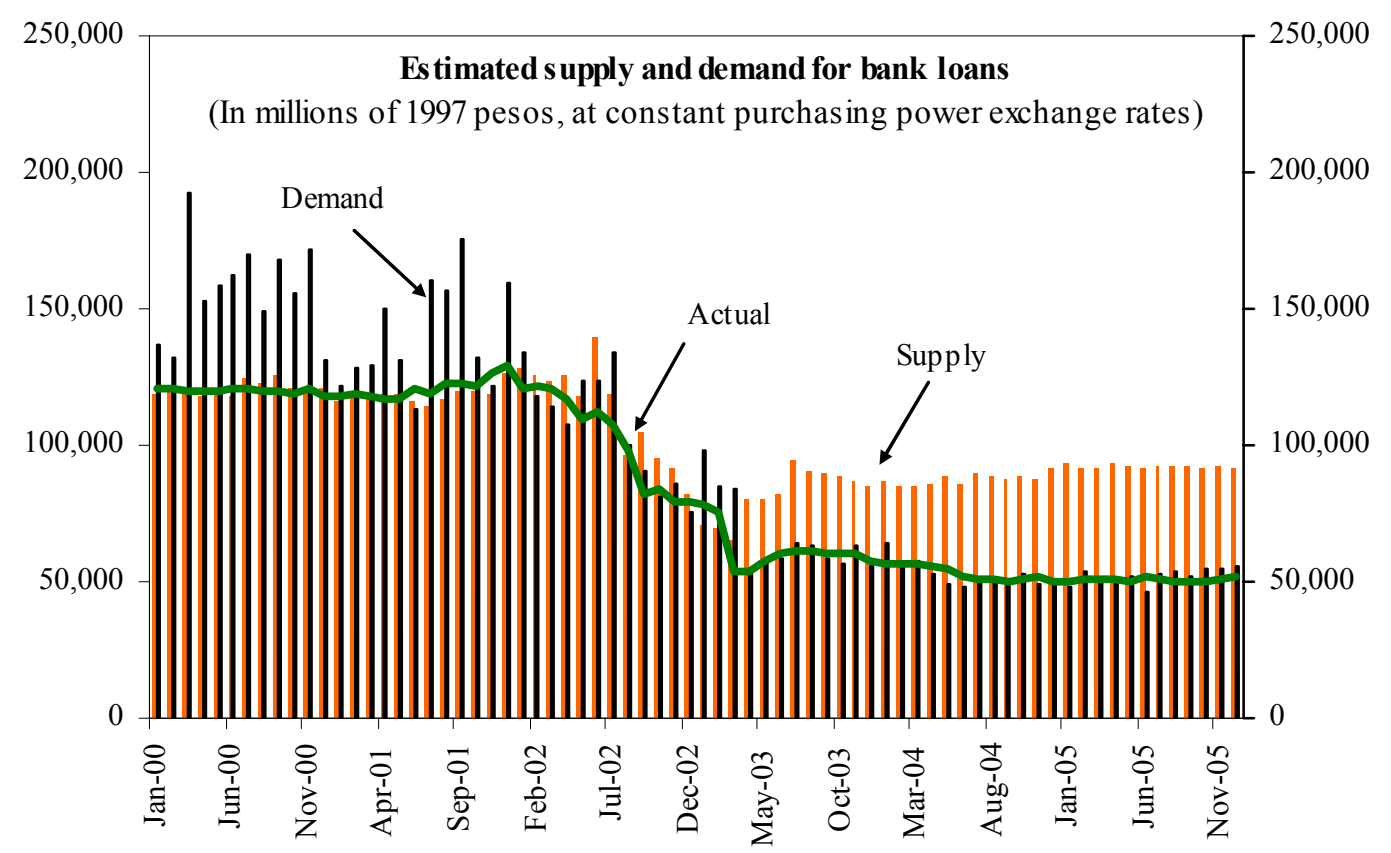

\section{Comparison with International Experience}

Macroeconomic developments after banking crises and implications for Uruguay

\section{The international experience shows that} after a banking crisis, output recovers relatively quickly but bank lending takes longer to resume. Although large variation across country experiences exists, often bank lending takes more than three years after the crisis (Figure 1) to recover (see also Demirgüç-Kunt, Detragiache, and Gupta, 2000, and Hoggarth and Reidhill, 2003). GDP growth typically takes off much quicker (Calvo, Izquierdo, and Talvi, 2006), so credit-to-GDP ratios stay low for an extended time. ${ }^{10}$ The drop in lending is stronger when the banking crisis coincides with a currency crisis (IDB, 2004) and in dollarized economies (see Gulde and others, 2003).

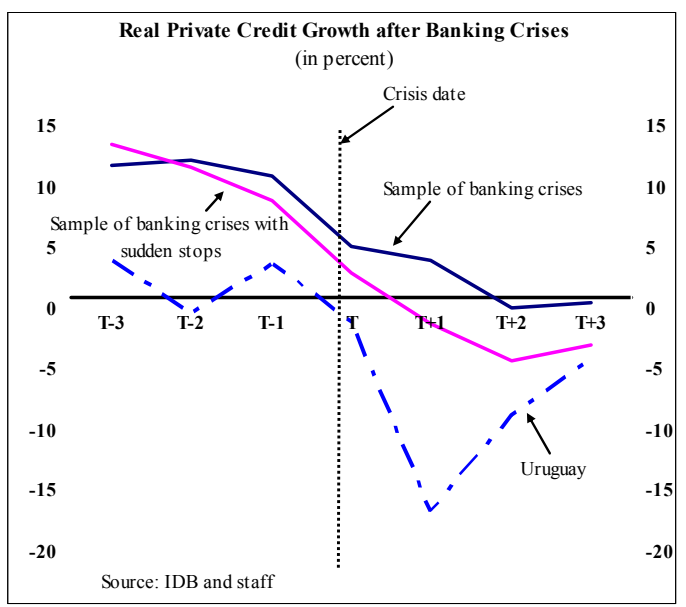

22. The stagnation in credit after banking crises is only partly attributable to a drop in deposits. Following banking crises, deposits fall somewhat, but the fall in bank credit to deposits is much larger (Figure 2). With four years after the onset of the crisis without a

\footnotetext{
${ }^{10}$ See also IDB (2004).
} 
recovery of bank credit, the experience of Uruguay appears consistent with that of other countries suffering banking crises.

\section{The use of spare capacity and the postponement of investment decisions}

typically explains the recovery of output after crises. Calvo, Izquierdo, and Talvi (2006) show that the capital stock remains relatively constant throughout the collapse-recovery phase, while investment collapses together with output, and recovers weakly when output regains pre-crisis levels. Krueger and Tornell (1999) and Tornell and Westermann (2002) also stress that exporters quickly find access to international credit and capital markets, but producers of nontradable goods needs to use other sources of financing.

\section{Several factors suggest the recovery could be sustained, at least for some time:}

a. Fixed investment has shown an upward trend since early 2003. This suggests the delay in investment decisions and the use of spare capacity have not been the main reasons explaining the low credit demand. Alternative sources of credit must be sustaining, at least in part, the recovery.

b. In the past, domestic bank credit was not the only source of finance, and the historical correlation

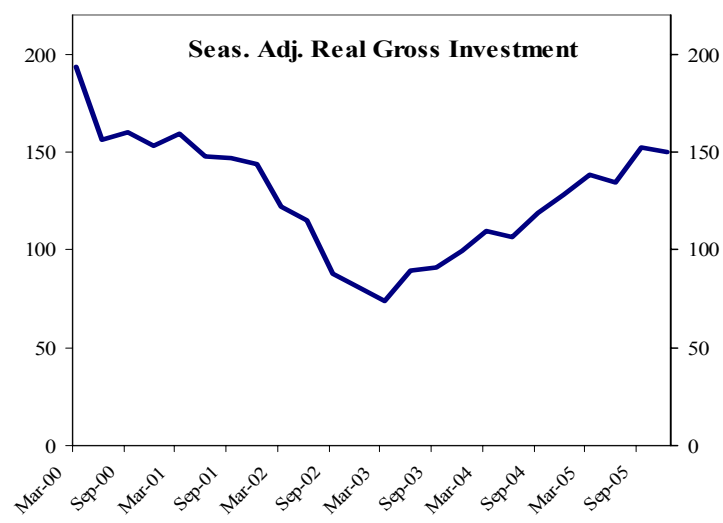
between output and bank credit is not high. While no comprehensive data are available, nondeposit-taking institutions have reportedly provided loans to both consumers and companies.

c. In Uruguay, the industries that typically depend substantially on financing, such as machinery and chemicals, are small. Dell'Ariccia, Detragiache, and Rajan (2005) document that the damaging effect of crises on output is stronger for industries that depend more on borrowed funds.

d. Except for BHU, Uruguayan banks are well capitalized. Failure to recapitalize banks after crises has sometimes contributed to a prolonged credit crunch (see Gulde and others, 2003). 
Figure 1. Lending to Private Sector Around Selected Banking Crises
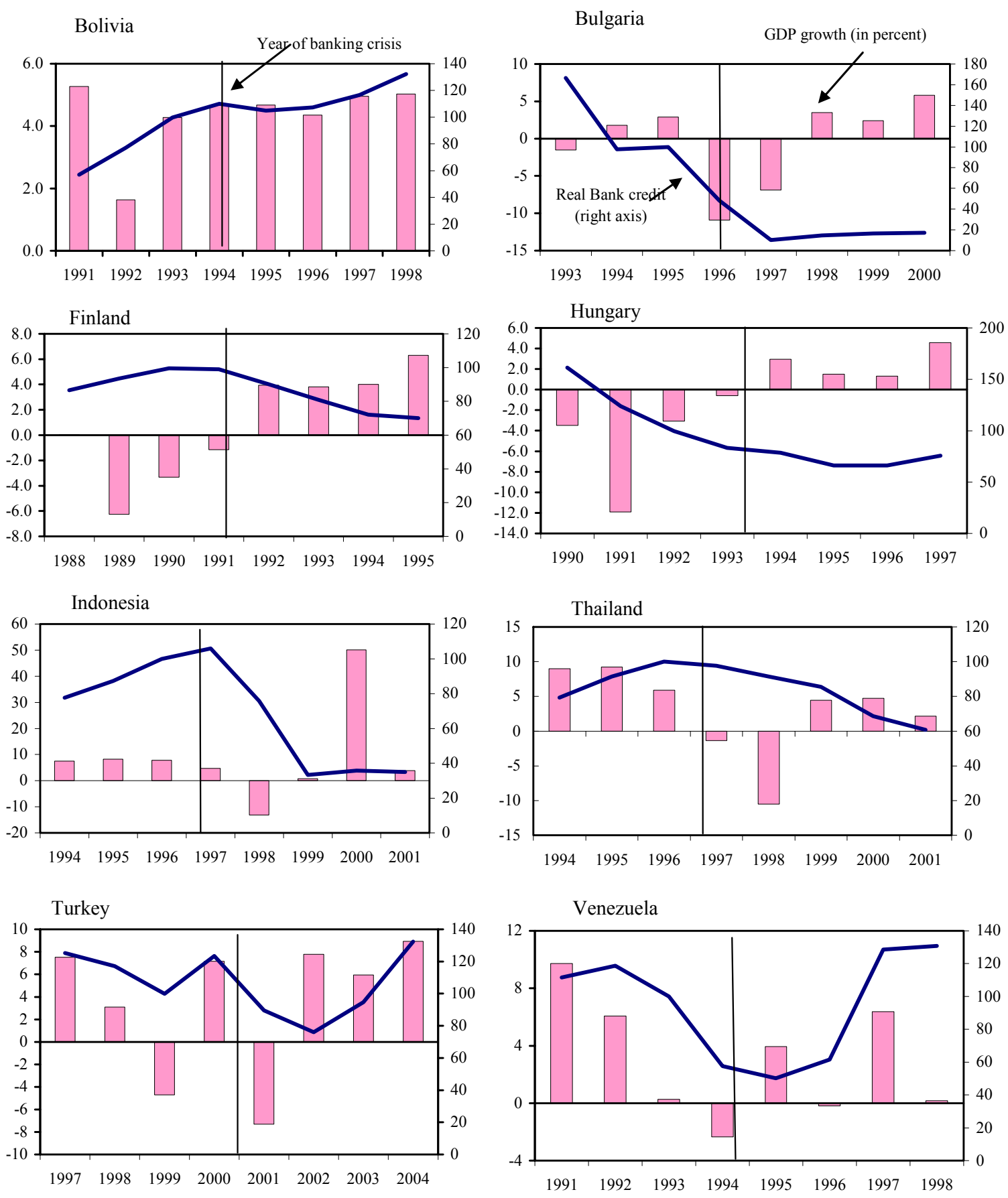

Source: IFS and Caprio and Klingebiel (2005). Levels of bank credit are normalized to equal 100 in the precrisis year and calculated at constant exchange rates thereafer. 
Figure 2. Evolution of Deposits and Lending Around Selected Banking Crises.
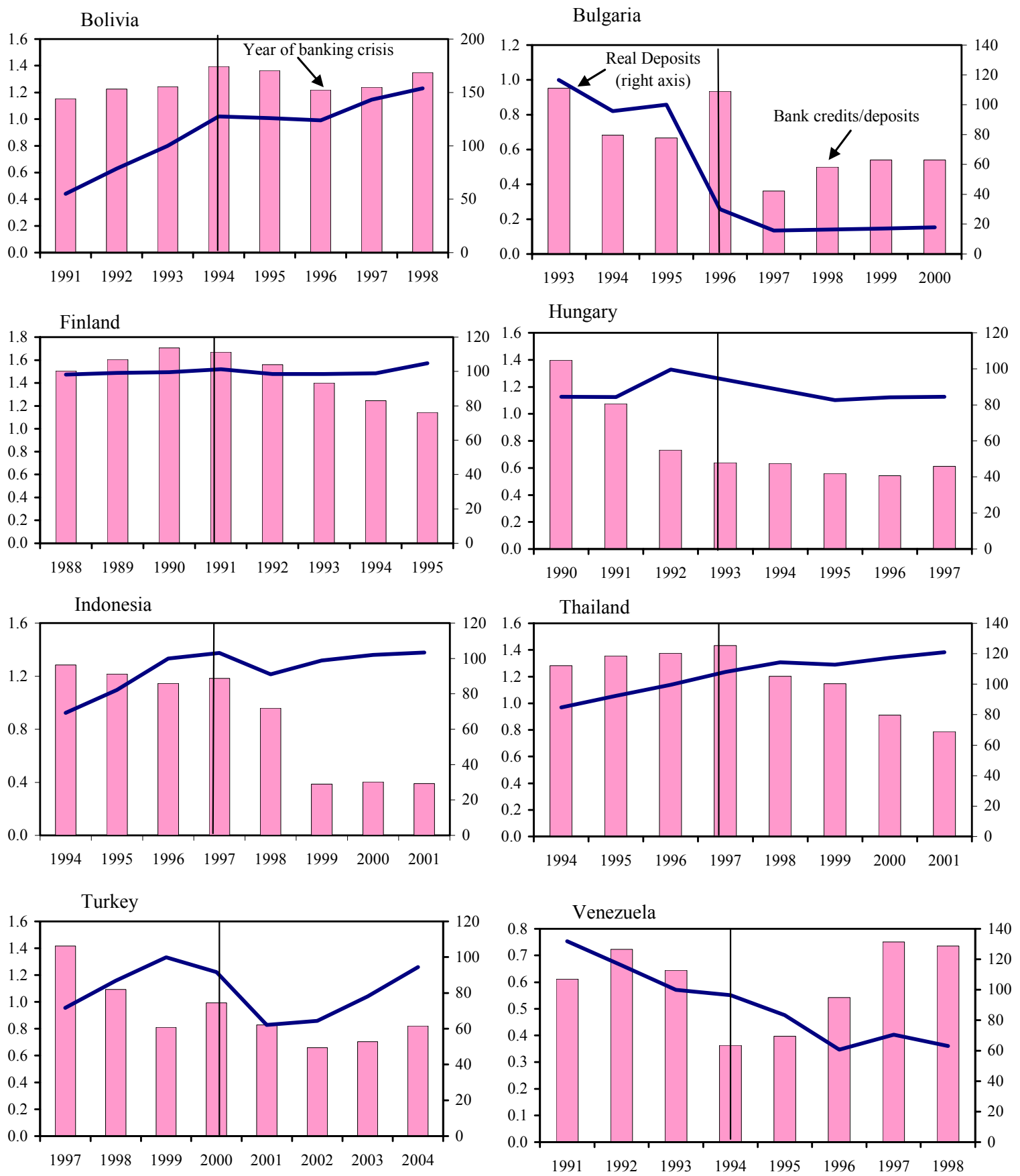

Source: IFS and Caprio and Klingebiel (2005). 


\section{E. What Should Be Done?}

\section{How can the authorities foster sound credit without undermining market} discipline and financial stability? A resumption of credit should without increasing or creating new vulnerabilities. Simply relaxing prudential norms would only plant the seeds for new weaknesses (Lindgren and others, 1999). The literature on how to encourage sound credit in post-crisis environments is scarce. Some recommendations may, however, be made:

\section{a. Encourage the dedollarization of the economy and the development of hedging} markets. Over 80 percent of deposits are in dollar, and with only a small fraction of companies with foreign-currency denominated earnings, the room for banks to lend without incurring credit risks due to corporate sector mismatches is limited. ${ }^{11}$

b. Improve the credit culture. This will require enforcing debt service obligations across sectors of the economy, extending coverage and dissemination of credit registry information, creating incentives to build a good credit history, and executing collateral in severely nonperforming loans. ${ }^{12}$ The authorities could explore shortening foreclosure processes, accelerating out-of-court procedures for debt collection, and adopting proceedings that minimize judicial intervention.

c. Encourage the development of short-term money markets. When money markets are deeper, banks need to hold less precautionary holdings of liquidity, enabling them to lend more. The development of bonds, certificates of deposits, and commercial paper markets could contribute to foster financial intermediation (see Feyzoglu and Gelos, 2000).

d. Assist in the development of trust funds and securitization (fideicomisos). Banks can use these financing instruments while companies' balance sheets are still recovering since they help to isolate the financing of specific projects from the bad balance sheets of borrowers. In addition, companies can use these instruments to obtain direct financing from the market. So far, however, only a few such securitizations have occurred and it would be useful to reduce tax and regulatory burden that impedes their development.

26. The government has been working on several relevant measures. For example, to encourage soundness in dollar credit, it has modified prudential regulations to internalize risks from dollar lending to unhedged borrowers, including through higher capital and provisioning requirements. To improve the credit culture, it is gradually expanding coverage of the credit registry and submitted to congress a bankruptcy law reform allowing to reorganize viable firms and liquidate nonviable ones faster and more efficiently.

\footnotetext{
${ }^{11}$ New prudential rules now penalize credit to firms that do not generate dollar income through higher up-front provisions.

${ }^{12}$ According to a recent World Bank Doing Business Survey, Uruguay scores relatively well on credit information availability. However, increased coverage would help assess credit risk better.
} 


\section{References}

Barajas, Adolfo, and Roberto Steiner, 2002, "Credit Stagnation in Latin America," IMF Working Paper 02/53 (Washington: International Monetary Fund).

Calvo, Guillermo A., Alejandro Izquierdo, and Ernesto Talvi, 2006, "Phoenix Miracles in Emerging Markets: Recovering Without Credit From Systemic Financial Crises” (unpublished manuscript; Washington: Inter-American Development Bank).

Catão, Luis, 1997, "Bank Credit in Argentina in the Aftermath of the Mexican Crisis: Supply or Demand Constrained," IMF Working Paper 97/32 (Washington: International Monetary Fund).

De Brun, Julio, Néstor Gandelman, Herman Kamil, and Arturo Porzecanski, 2006, "The Fixed-Income Market in Uruguay," mimeo IADB.

Demirguc-Kunt, Detragiache, and Poonam Gupta, 2000, "Inside the Crisis: An Empirical Analysis of Banking Systems in Distress,” IMF Working Paper 00/156 (Washington: International Monetary Fund).

Feyzoglu, Tarhan, and Gaston Gelos, 2002, "Why is Private Sector Credit so Low in Bulgaria," in Bulgaria: Selected Issues and Statistical Appendix (Washington: International Monetary Fund).

Ghosh, Swati R., and Atish Ghosh, 1999, "East Asia in the Aftermath: Was There a Credit Crunch?” IMF Working Paper 99/38 (Washington: International Monetary Fund).

Gilli, B., 2005, “Estructura de Capital de las Empresas Uruguayas en el Marco de la Teoría de Jerarquía de Preferencias," (Valencia: Universidad de Valencia)

Gulde and others, 2003, "Dealing with Banking Crises in Dollarized Economies," in Managing Financial Crises: Recent Experience and Lessons for Latin America, ed. by Charles Collyns, and G. Russell Kincaid," IMF Occasional Paper No. 217 (Washington: International Monetary Fund).

Hoggarth, Glenn, Jack Reidhill, and Peter Sinclar, 2004, "On the Resolution of Banking Crises: Theory and Evidence,” Bank of England Working Paper 229.

Inter-American Development Bank, 2004, "Unlocking Credit—The Quest for Deep and Stable Bank Lending." 
Kiefer, Nicholas, 1980, “A Note on Regime Classification in Disequilibrium Models,” Review of Economic Studies, Vol. 17, pp. 637-639.

Krueger, Anne, and Aaron Tornell, "The Role of Bank Restructuring in Recovering from Crises: Mexico 1995-98,” NBER Working Paper 7042.

Laffont, Jean-Jacques, and Rene García, 1977, “Disequilibrium Econometrics for Business Loans," Econometrica, Vol. 45.

Levine, Ross, 2005, "Finance and Growth: Theory and Evidence," in Handbook of Economic Growth, ed. by Philippe Aghion and Steven Durlauf (The Netherlands: Elsevier Science).

Licandro, Gerardo, 2006, “Los balances y el crédito bancario,” El País - Opinión (Montevideo), May 15.

Lindgren and others, 1999, "Financial Sector Crisis and Restructuring," IMF Occasional Paper No.188 (Washington: International Monetary Fund).

Maddala, G., and Forrest Nelson, 1974, "Maximum Likelihood Methods for Models of Markets in Disequilibrium," Econométrica, Vol. 42, No. 6, pp. 1013-1030.

Munyo, Ignacio, 2005, “The Determinants of Capital Structure: Evidence from an Economy without a Stock Market,” Draft Universidad de la República (September).

Pazarbasioglu, Ceyla, 1996, "A Credit Crunch? A Case Study of Finland in the Aftermath of the Banking Crisis,” IMF Working Paper 96/135 (Washington: International Monetary Fund).

Sealey, C.W., 1979, "Credit Rationing in the Commercial Loan Market. Estimates of a Structural Model Under Conditions of Disequilibrium," Journal of Finance, Vol. 34, pp. 689-702.

Stiglitz, Joseph, and Andrew Weiss, 1981, "Credit Rationing in Markets with Imperfect Information," American Economic Review, Vol. 71, pp. 393-410.

Tornell, Aaron, 1999, "Common Fundamentals in the Tequila and Asian Crises," NBER Working Paper No. 7139.

Tornell, Aaron, and Frank Westermann, 2002, "The Credit Channel in Middle Income Countries," NBER Working Paper No. 9355. 


\section{Estimation Results}

Table A1: Uruguay Credit Supply and Demand Estimations (Maximum Likelihood disequilibrium estimation)

\begin{tabular}{|c|c|c|c|c|}
\hline $\begin{array}{l}\text { Dependent } \\
\text { variable }\end{array}$ & $\begin{array}{l}\text { Real total credit } \\
\text { to the private } \\
\text { sector } \\
\text { (1) }\end{array}$ & $\begin{array}{l}\text { Real total Adj. } \\
\text { credit to the } \\
\text { private sector } \\
(2)(*)\end{array}$ & $\begin{array}{l}\text { Real total credit } \\
\text { to the private } \\
\text { sector } \\
\text { (3) }\end{array}$ & $\begin{array}{l}\text { Real total credit } \\
\text { to the private } \\
\text { sector } \\
\text { (4) }\end{array}$ \\
\hline \multicolumn{5}{|l|}{ Supply } \\
\hline Constant & $\begin{array}{r}10.412 \\
(2.42)\end{array}$ & $\begin{array}{r}10.404 \\
(2.45)\end{array}$ & $\begin{array}{l}7.434 \\
(2.68)\end{array}$ & $\begin{array}{r}13.848 \\
(7.56)\end{array}$ \\
\hline Real lending & 0.144 & 0.144 & 0.098 & 0.129 \\
\hline capacity & (4.92) & (4.98) & $(7.01)$ & (2.04) \\
\hline Local currency & 0.007 & 0.007 & 0.001 & 0.004 \\
\hline spread & $(5.21)$ & $(5.26)$ & $(1.20)$ & $(1.70)$ \\
\hline Foreign & 0.005 & 0.005 & 0.012 & 0.007 \\
\hline currency spread & $(0.23)$ & $(0.241)$ & $(0.56)$ & $(1.17)$ \\
\hline Non performing & -0.078 & -0.078 & 0.010 & -0.029 \\
\hline loans ratio & $(0.59)$ & $(0.59)$ & $(0.09)$ & $(0.87)$ \\
\hline \multirow[t]{2}{*}{ Provision ratio } & -0.27 & -0.273 & 0.041 & -0.134 \\
\hline & $(1.52)$ & $(1.54)$ & $(0.16)$ & $(2.89)$ \\
\hline \multirow[t]{2}{*}{ Real GDP } & -0.19 & -0.189 & 0.593 & -0.786 \\
\hline & $(0.22)$ & $(0.22)$ & $(1.08)$ & $(2.61)$ \\
\hline Leading activity & - & - & - & \\
\hline indicator & - & - & - & \\
\hline \multicolumn{5}{|l|}{ Demand } \\
\hline \multirow[t]{2}{*}{ Constant } & 9.848 & 9.851 & 9.834 & 13.138 \\
\hline & $(32.28)$ & (32.38) & (36.11) & (12.63) \\
\hline \multirow[t]{2}{*}{ Dummy $(* *)$} & 0.398 & 0.397 & - & - \\
\hline & $(4.61)$ & $(4.60)$ & - & - \\
\hline Real local & -0.004 & -0.004 & 0.010 & 0.002 \\
\hline $\begin{array}{l}\text { currency } \\
\text { lending rate }\end{array}$ & $(2.74)$ & $(2.75)$ & $(5.68)$ & $(2.81)$ \\
\hline Foreign & 0.226 & 0.225 & 0.123 & 0.165 \\
\hline $\begin{array}{l}\text { currency } \\
\text { lending rate }\end{array}$ & (13.49) & (13.48) & $(7.21)$ & (9.33) \\
\hline Leading activity & - & - & - & -0.458 \\
\hline indicator & - & - & - & $(2.68)$ \\
\hline \multirow[t]{2}{*}{ Output gap } & 0.020 & 0.020 & 0.012 & \\
\hline & (3.19) & $(3.19)$ & $(2.82)$ & \\
\hline Expected & -0.022 & -0.022 & -0.030 & -0.029 \\
\hline inflation & $(3.73)$ & $(3.74)$ & $(7.27)$ & $(7.02)$ \\
\hline Sovereign risk & -0.071 & -0.071 & 0.038 & -0.182 \\
\hline index & $(1.57)$ & $(1.56)$ & (1.05) & (3.37) \\
\hline Log likelihood & 129.425 & 129.825 & 151.950 & 153.875 \\
\hline
\end{tabular}

Estimation period 1998:12 - 2005:12. Number of observations: 84. t-statistics shown in parentheses. Foreign currency credit stock and foreign currency amounts in lending capacity definition are converted using an exchange rate that maintains the purchasing power constant throughout the estimation period.

(*) Credit series in that column was adjusted with loan writeoffs and the loan portfolio of the banks liquidated during the crisis. $(* *)$ Dummy variable captures the level effect on credit demand during the outlier explosive period of local currency lending rate: Dec.2001-Mar.2003. 


\section{OPTIONS TO INCREASE INFRASTRUCTURE INVESTMENT IN URUGUAY ${ }^{1}$}

\section{A. Introduction}

1. This paper examines Uruguay's expected needs for, and options to achieve, higher infrastructure spending, balancing fiscal considerations and social preferences. With public debt still high at around 70 percent of GDP, large primary surpluses will continue to be needed. At the same time, Uruguayan society's support for a large role of the state in the economy and rejections of outright privatization also impose important constraints. Section B presents a brief review of the literature on public investment and growth. Section $\mathrm{C}$ discusses recent trends in public investment in Uruguay, with emphasis on infrastructure. Section D looks at the scope to increase public investment and reviews the institutional budget and investment processes. Section E draws lessons from international experience to strengthen private sector participation in infrastructure. The conclusions are presented in section $\mathrm{F}$.

2. Uruguay has done remarkably well in maintaining a good quality of public infrastructure, but a recent decline in public investment raises concerns looking ahead. The fiscal retrenchment prompted by the recession that begun in 1999 and deepened after the 2002 financial crisis, has brought government's capital spending from above 4 percent of GDP down to 2.3 percent of GDP in 2005. Notwithstanding, infrastructure indicators show that the country still enjoys good levels of provision of basic services, and compares favorably with other countries in the region in this regard.

3. The challenge for Uruguay is to increase investment in infrastructure to sustain the ongoing economic recovery into the medium term. After falling by 16 percent during 1999-2002, the economy has rebounded vigorously in 2003-2005, averaging 7 percent GDP growth per year. However, to preserve strong growth beyond the recovery from the crisis, emerging bottlenecks in infrastructure would need to be addressed. To this end, both increased public investment, financed by higher public savings, and increased private sector participation will be required.

\section{Current plans to increase public savings to finance higher investment are in} the right direction. Given the high public debt, there is no room for loosening the fiscal stance. The five-year budget envisages increases in investment of about 1 percent of GDP financed by higher revenues. With the revenue-to-GDP ratio targeted to reach almost 34 percent in 2009, further increases would risk imposing an excessive burden on the private sector. Additional room for investment should be created through reductions in other expenditures and from more efficient government spending.

5. Increased private sector involvement could play a major role in strengthening public infrastructure. Given the low private participation in infrastructure (PPI) in

\footnotetext{
${ }^{1}$ Prepared by Alejandro Hajdenberg (FAD).
} 
Uruguay, there is ample room to move in this direction. Efforts should be devoted to developing an attractive environment for the private sector, and the government is already planning an increased role for public-private partnerships (PPPs). International experience indicates that PPPs can be effective in expanding infrastructure, but may also pose risks. Necessary conditions to establish efficient and fiscally sound PPPs include building capacity of government entities to develop PPPs, adequately share risks with the private sector, and properly evaluate and record the fiscal costs of PPP.

\section{B. Public Investment and Growth in the Literature}

\section{Empirical studies on the impact of public investment on growth are} inconclusive. An early study by Aschauer (1989) found a positive cross-country correlation between public investment and productivity growth, and similar results were found by studies using the same methodology. However, subsequent work found that the outcomes were not robust to more sophisticated econometric techniques and the data employed (Holtz-Eakin, 1994; Cashin, 1995; and Gramlich, 1994). The lack of clear-cut results may have several causes: due to inefficiency or corruption, capital spending may not translate into productive assets; public investment includes elements that do not add to the productive capacity of the economy; data used in these studies often refer to gross investment rather than net, and when net data are available, their quality is affected by measurement problems of depreciation and spending on investment maintenance.

\section{The literature finds stronger links between investment in infrastructure and} growth, but further work is needed on the impact of the composition of public spending. Several cross-country studies have found a positive relation between various measures of infrastructure and the level and growth of output. Surveys by BriceñoGarmendia et al. (2004) and by Calderón and Servén (2005) report that most recent studies find a positive impact of infrastructure on output levels, although there is variation across countries. Easterly and Rebelo (1993) and Calderón and Servén (2004b) find that investment in different components of infrastructure has a positive effect on growth. More generally, a review by Romp and de Haan (2005) concludes that consensus about the growth-enhancing effect of public infrastructure has increased, although the impact is much lower than those estimated by earlier studies, and that this impact varies significantly across countries, regions, and sectors. More work is needed, however, to understand how the composition of public spending as a whole, including on infrastructure, affects growth.

\section{Investment Developments}

\section{Declining public investment could affect Uruguay's ability to maintain the} good quality of its infrastructure and sustain high rates of economic growth. Public investment has declined substantially since 1999 and there has been historically limited involvement of the private sector in infrastructure. While public infrastructure is in good condition, going forward, significant investments will be required to maintain this standard and address emerging bottlenecks that could stifle economic growth. 
9. The fiscal adjustment undertaken by Uruguay has led to a sharp contraction of public investment. Between 1999 and 2005 the primary balance increased by 6 percentage points of GDP (Table 1). With lower revenues by close to $1 \frac{1}{2}$ percent of GDP, this adjustment implied large reductions in current and capital spending. Capital spending fell by more than 40 percent, from 4 to 2.3 percent of GDP, a low level relative to the region (Figure 1). This is accentuated by the fact that, in contrast to Uruguay, in most of the other countries the role of the state has declined since the 1990s when infrastructure was opened to the private sector.

\begin{tabular}{|lrrr|}
\hline \multicolumn{4}{|c|}{ Table 1. Selected Fiscal Indicators. 1999-2005 } \\
\hline & 1999 & 2005 & Change \\
Revenue & 33.3 & 31.8 & -1.4 \\
Non-interest expenditure & 35.4 & 27.9 & -7.5 \\
$\quad$ Current expenditure & 31.1 & 25.6 & -5.5 \\
Capital expenditure & 4.3 & 2.3 & -1.9 \\
Primary balance & -2.1 & 3.9 & 6.0 \\
Public saving & 2.1 & 6.2 & 4.1 \\
\hline
\end{tabular}

Source: Ministry of Finance.

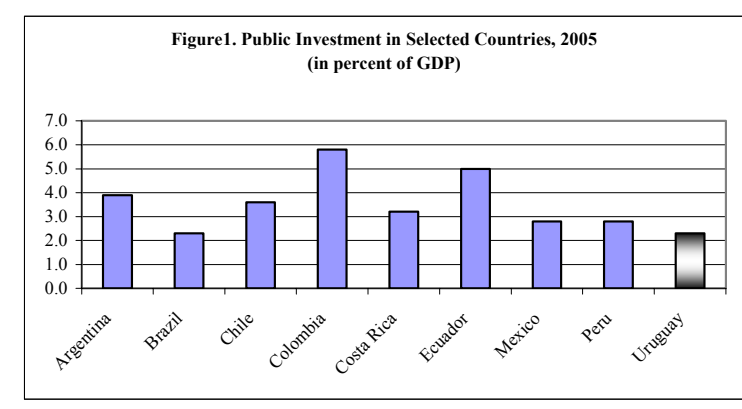

Source: Ministry of Finance.

10. Given the small private role in this area, declining public investment has also had a negative impact on investment in infrastructure. Between 1999 and 2005 public investment in infrastructure ${ }^{2}$ declined by about 30 percent, from 2.2 percent of GDP to 1.6 percent, even if the share of infrastructure in total investment increased. Despite the contraction, the level of spending still compares favorably with the region. Servén (2004a) reports that public investment in infrastructure in six Latin American countries averaged only 0.8 percent of GDP in the period 1996-2001 (down from 3.1 percent of GDP in the 1980s).

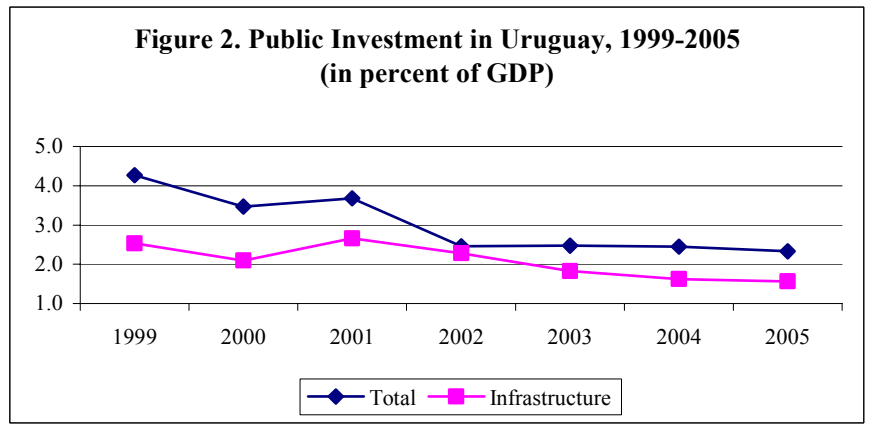

Sources: Ministry of Finance and Fund staff estimates.

\footnotetext{
${ }^{2}$ These figures are an approximation to spending on infrastructure, corresponding to investment by the public enterprises and the Ministry of Transportation.
} 


\section{Private participation in infrastructure (PPI) has played a small role in Uruguay.} Infrastructure services are largely provided by monopolistic state owned enterprises (SOEs). Uruguayans have historically favored a large role for the government in income distribution as well as in the provision of public services. Consequently, PPI in Uruguay averaged only 0.5 percent of GDP in the period 1990-2004. This low level contrasts with the experiences in other countries in the region, where since the 1990's an increase in private sector investment, in particular in transportation, energy and telecommunications, has partially compensated for lower public spending.

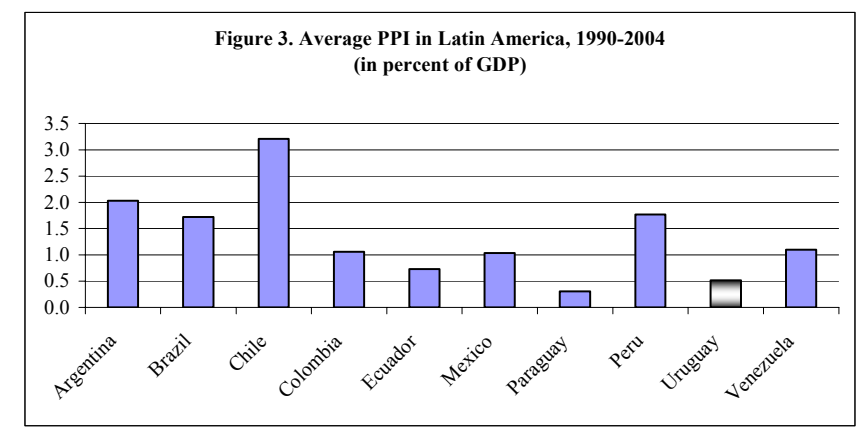

Source: The World Bank, Private Participation in Infrastructure Database.

12. There is significant public opposition to an expanded role of the private sector in infrastructure. The Uruguayan Constitution stipulates that 25 percent of the registered voters can initiate a referendum appeal to repeal a law within one year of its adoption. On this basis, successful referenda took place in 1992 to prevent partial privatization of the telecommunications company, in 2003 to impede the association of the state-oil company Ancap with private partners and eliminate Ancap's monopoly in the imports of fuel, and in 2004 to ban concessions for provision of water and sanitation services.

13. Nevertheless, there has been some experience with PPI, with mixed results. In Uruguay, PPI has mostly taken the form of concessions to build and operate infrastructure, and joint-ventures of the SOEs with private companies (Box 1). Concessions in road construction and management, gas transportation and distribution, port services, and airport management have fared relatively well, despite some contract cancellations and renegotiations. Private provision of sanitation services was vetoed by a referendum held in 2003 and this led eventually to the withdrawal of the main private operators from this sector. Private participation in mobile communications and long distance calls, in competition with the public company, has resulted in a significant improvement in quality and reduction of tariffs. In 1995 the state-owned airline was partially privatized through the sale of 51 percent of its stake in the company, but the company has suffered from recurrent financial difficulties. 


\section{Box 1. Private Participation in Infrastructure in Uruguay}

Uruguay has had some experiences with PPI but the volume of investment has been small. The following are the main projects:

- $\quad$ Roads. Since 1993 there have been four road concessions. Under these concessions, the private operators committed to invest in construction and maintenance, and are financed through tolls and, in some cases, government subsidies. The road Montevideo-Punta del Este, awarded in 1994, is the oldest concession and the only one relying solely on toll revenues. Under the contracts for Roads 5 and 8 , the operators receive a fixed government subsidy in construction materials. The contract for road 1 has been recently revoked due to delays in construction execution.

- $\quad$ Port. The port of Montevideo operates under a landlord model, in which the state-owned port administration company, ANP, owns the basic infrastructure (quays, docks, storage yards) while private concessionaires build superstructure facilities such as office buildings, furnish equipment such as cranes, operate the port facilities, and pay a canon to the State.

- $\quad$ Airport. A concession to operate and maintain Uruguay's main airport was awarded to a private company in 1993.

- Natural gas. One of the two natural gas lines transporting gas from Argentina was built, and is operated under a 30 year concession, by a private company, with a minority stake owned by Ancap. The three existing gas distribution networks are private.

- Telecommunications. There are two private operators of mobile communications in competition with the state-owned company, Antel. Antel also competes with the private sector in data services, while it retains the monopoly of fixed-line telephony.

- Oil. Gasoline distribution involves three private operators, but Ancap still distributes the largest share of the total. Ancap retains the monopoly of oil and oil derivatives imports and refining.

- Drinking water and sanitation. Concessions for the provision of these services were awarded in 1992 and 2001. A referendum in 2003 introduced a constitutional reform banning provision of these services by the private sector. Since then, one of the two largest existing concessions was revoked, and the other one was partially taken over by the state.

\section{Uruguay has been able to maintain its infrastructure generally in good} condition but there are some weaker areas. The World Bank (2005a) reports that in general, there is a high level of coverage, access, and quality of basic services (Table 2). The road network's density and the condition of the primary road network are among the best in Latin America. Port services are competitive within the region, and telephony coverage is high. Electricity reaches the entire population, but lack of investment to keep up with increased demand has left the system vulnerable to adverse weather conditions. Water quality is good, with almost universal coverage, but sewerage access is very low outside of Montevideo. There are also some problems with access to natural gas, mainly 
due to the small size of the distribution network. Finally, railway services are not competitive and freight volumes are low. Regarding tariffs, public enterprises often set high levels, due to low efficiency, but also to generate fiscal revenues. In particular, gasoline prices are among the highest in the region.

Table 2. Infrastructure Indicators, 1990 and 2002 1/

\begin{tabular}{|c|c|c|c|c|c|c|c|c|c|c|}
\hline & \multicolumn{2}{|c|}{$\begin{array}{c}\text { Fixed and Mobile } \\
\text { Telephone Lines } \\
\text { (Subscribers per } 1,000 \text { people) }\end{array}$} & \multicolumn{2}{|c|}{$\begin{array}{l}\text { Electricity Generation } \\
\text { (Kwh per capita) }\end{array}$} & \multicolumn{2}{|c|}{$\begin{array}{c}\text { Roads } \\
\text { (Km per } 1,000 \text { people })\end{array}$} & \multicolumn{2}{|c|}{$\begin{array}{c}\text { Paved Roads } \\
\text { (in percent of total roads) }\end{array}$} & \multicolumn{2}{|c|}{$\begin{array}{l}\text { Access to Improved Water Sources } \\
\text { (in percent of the population) }\end{array}$} \\
\hline & 1990 & 2002 & 1990 & 2002 & 1990 & 2002 & 1990 & 2002 & 1990 & 2002 \\
\hline $\begin{array}{l}\text { Uruguay } \\
\end{array}$ & 134 & 472 & 2,397 & 2,858 & 3.1 & 2.7 & 74 & 90 & $\ldots$ & 98 \\
\hline Argentina & 93 & 396 & 1,580 & 2,253 & 6.7 & 5.9 & 29 & 29 & 94 & .. \\
\hline Brazil & 65 & 424 & 1,506 & 1,975 & 11.3 & 10.3 & 10 & 6 & 83 & 89 \\
\hline Chile & 67 & 659 & 1,403 & 2,918 & 6.1 & 5.3 & 14 & 19 & 90 & 95 \\
\hline Colombia & 69 & 286 & 1,034 & 1,032 & 3.1 & 2.7 & 12 & 14 & 92 & 92 \\
\hline High income 2/ & 463 & 1,230 & 8,146 & 9,678 & 14.3 & 14.0 & 85 & 95 & . & 99 \\
\hline Middle income & 41 & 322 & 1,478 & 1,868 & 3.1 & 2.9 & 52 & 54 & 77 & 83 \\
\hline Low income & 6 & 40 & 303 & 410 & 2.1 & 2.1 & 15 & 15 & 6 & 75 \\
\hline World & 102 & 364 & 1,478 & 1,868 & 4.7 & 4.4 & 38 & 48 & 26 & 82 \\
\hline
\end{tabular}

Source: The World Bank (2005)

1/ Latest year available were indicated

2/ Income groups are based on the World Bank classification in 2005.

15. Uruguay fares relatively well in international comparisons of infrastructure levels. The literature reports that since the 1980s Latin America has lagged relative to other regions in infrastructure provision. This is explained by a fiscal retrenchment that was only partially offset by private sector investment. ${ }^{3}$ Infrastructure levels and quality in Latin America now lag behind not only the successful Asian economies, but in many cases also the middle-income developing countries. In this context, Uruguay and Chile stand out as the best performers in the region. This is confirmed by Uruguayans' own perception of their infrastructure as surveyed by the Global Competitiveness Report, which ranks Uruguay second, after Chile, among the Latin American countries.

16. However, as Uruguay recovers from the $\mathbf{2 0 0 2}$ crisis, sustaining growth will require addressing emerging infrastructure bottlenecks. The following are considered to be the main areas requiring increased investment in the coming years:

- $\quad$ Electricity. Uruguay's electricity generation capacity could become a major bottleneck. The droughts in 2005 and 2006 resulted in significantly higher generation costs and measures to ration electricity. Ensuring reliable electricity supplies requires installing additional generating capacity and upgrading the interconnection with Brazil.

\footnotetext{
${ }^{3}$ See Calderón and Servén (2004b).
} 
- $\quad$ Railways. Increased freight transportation demand, after the pulp mills begin operations in 2007, is expected to be partially satisfied by the railway. This requires investments to upgrade the railway network and equipment.

- $\quad$ Roads. While the road network is in good condition, the budgeted level of spending in maintenance and rehabilitation is considered insufficient to prevent its deterioration. Pressures could also come from increased transportation related to the pulp mills.

- $\quad$ Ports. Uruguay is trying to position itself as a regional port hub. Attaining this goal would require, among other actions, dredging the port of Montevideo, upgrading its terminal facilities, and developing smaller ports.

- $\quad$ Sanitation. With sewerage coverage being one of the areas where Uruguay lags behind, sanitation coverage outside of Montevideo needs to be significantly expanded to reach a larger fraction of the population.

\section{Options to Promote High Quality Public Investment}

\section{Achieving higher and better public investment will require higher public} savings and strengthening budgetary and investment processes. Given the constraints imposed by the high level of debt, there is little room to relax the fiscal stance. The 20052009 budget has public investment increasing by about 1 percent of GDP, financed by increased revenues. However, revenues are projected to reach 34 percent of GDP in 2009, and further increases would risk putting an excessive burden on the economy. Additional space for investment should come from reforms to lower current spending. In addition, strengthening the institutional budget and public investment processes would also improve the efficiency of spending.

\section{Large increases in savings would be difficult to achieve due to existing budget rigidities.}

- While earmarking of revenues is not particularly severe by regional standards, there is some scope to free resources through increased flexibility in this area. About $1 / 3$ of revenues have some sort of earmarking, but to a large extent this constraint is not binding. The proposed tax reform, while reducing earmarking through the elimination of several of the earmarked taxes, does not reduce rigidities as minimum spending requirements are being introduced to maintain the levels of spending currently implemented through revenue earmarking.

- $\quad$ The main rigidity stems from the high level of non-discretionary spending. With close to 60 percent of all spending on wages and social security benefits (Figure 4), meaningful savings would require politically difficult cuts of these categories. In the case of wages, with average salaries relatively low, possible savings would likely be small and based on reductions in employment. Moreover, while civil service reform is 
being considered, the main goal would be to improve efficiency and service delivery. Pension outlays are high by international standards, mostly reflecting Uruguayan demographics. The system was already reformed in 1996 and outlays are projected to decline gradually over the medium term. There is also room to achieve savings on discretionary spending through reform of procurement processes.

19. Addressing budgetary rigidities would also be important to protect investment levels at times of fiscal difficulties. The budget sets expenditure ceilings but the government can cap spending below those ceilings by decree, based on periodic assessments of revenue collections. These caps are a practical mechanism to ensure meeting fiscal objectives, as they can be imposed on all categories of spending with the exception of wages. However, given the large share of non-discretionary spending, cuts tend to fall on a few items, and in particular on capital spending. Similarly, the government also resorts to limit capital spending by the SOEs to meet its fiscal targets.

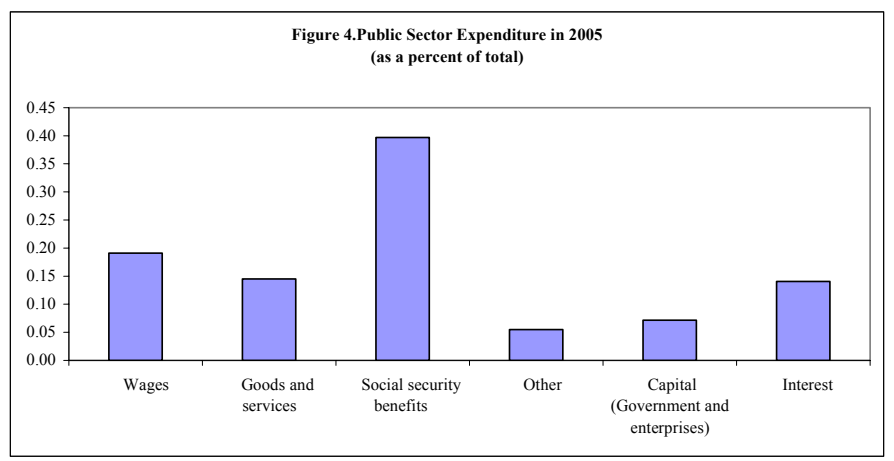

Source: Ministry of Finance

20. While important progress has been done, further strengthening the institutional budget process would be important to improve resource allocation. During the last budget cycle important improvements were introduced, including clearly stated government priorities, a medium-term macroeconomic framework, and revenue projections for the entire period. In addition, efforts were made to strengthen the strategic component of the budget. However, some remaining weaknesses should be addressed:

- $\quad$ The existing medium term budget framework is inadequate. A five-year budget is prepared to coincide with the presidential term but there are no annual updates. Development of a rolling medium budget framework is key to guide line ministries investment plans and ensure that these are consistent with available resources and macroeconomic stability.

- $\quad$ There is limited annual reassessment of priorities. The annual execution assessments allow modifications to the five-year budget in response to changing priorities. However, in practice few changes are made.

- The current institutional arrangement implies some coordination risks regarding the capital and current components of the budget. This is because the budget is formulated by two separate entities, the Ministry of Finance and the Office of Budget and Planning (OBP), which reports directly to the president. The MEF and the OBP are in charge of the current and capital budgets, respectively. 
21. The effectiveness of public investment could be enhanced by improving the appraisal and selection of investments. The quality of procedures for selection and evaluation of projects vary across the different levels of government and SOEs. In addition, lack of coordination between the spending units sometimes results in duplication of efforts and wasted resources. Specifically:

- $\quad$ There is considerable scope to increase investment selection procedures at the central government level. Spending units submit proposals to the OBP, describing costs and goals of their projects, for their evaluation and inclusion in the budget. But with the exception of large transportation projects and projects financed by international organizations, no adequate cost benefit analysis is performed, preventing comparisons of projects based on their estimated returns. This, combined with insufficient staff at the OBP to assess a large amount of projects (about 600 were included in the current budget) precludes adequate prioritization of projects.

- $\quad$ Local governments have limited capacity to develop and assess investment projects. Investment by the local governments is approved by the local councils and submitted to congress for informational purposes. Local government investment is largely financed by central government transfers, and in general they require the central administration's assistance to design the projects.

- $\quad$ Investment projects by the SOEs are generally well prepared. They are submitted as part of the company's business plan to the OBP for their approval. Projects above US\$ 1 million or 10 percent of the company's investment budget are subject to adequate cost-benefit analysis, including their economic and social return.

22. Monitoring and ex-post evaluation of investment projects need to be expanded at all levels of government. The assessment of investment projects is carried out annually in the context of the budget execution report. Financial information on project execution is good but data on physical progress are scarce. Also, no ex-post evaluations are performed, with the exception of externally financed projects, to determine whether stated goals formulated at the onset of the project were achieved and whether the costs were in line with original estimates. Better monitoring and ex-post evaluation would be important tools to assess the productivity of public investment and provide feedback for subsequent projects.

\section{E. Public-Private Partnerships}

23. Given fiscal constraints and public opposition to privatization, PPPs could be an important vehicle to increase investment and its efficiency, but risks need to be properly addressed. International experience shows that flaws in the design of PPPs could result in significant fiscal costs (Box 2). For this reason, development of PPPs should be done gradually allowing to gain experience, and fiscal risks reduced by strengthening the institutional framework and adequately sharing risks with the private sector. 


\section{Box 2. PPPs}

What is a PPP? The term public-private partnership refers to an arrangement by which the private sector supplies infrastructure assets and services that have traditionally been provided by the public sector. The most common form of PPP is one where the government enters into a long-term contract with a private partner to supply specified services, and the private partner is responsible for designing, building, financing, and operating the assets required to delivered these services. The private operator will typically own the PPP asset while operating it, but there is usually provision for the asset to be transferred to the government when the operating contract ends.

Advantages of PPPs. A successful PPP delivers high-quality services at lower cost than the government. It is the ability of the private sector to better coordinate and provide innovative approaches to manage the closely related activities mentioned above -and the risks associated with them- that is the principal source of efficiency gains from PPPs. PPPs are attractive from the point of view of the government because by providing financing for the projects they relieve the fiscal constraint.

Risks of PPPs. PPPs involve a range of different risks. These can be usefully divided into five, somewhat overlapping categories: construction risk, which is related to design problems, building cost overruns, and project delays; financial risk, which is related to variability in interest rates exchange rates, and other factors affecting financing costs; performance risk, which is related to the availability of an asset, and the continuity and quality of service provision; demand risk, which is related to the ongoing need for services; and residual value risk, which is related to the future market price of an asset. PPPs seek to transfer risk from the government to the private sector. However, when the government retains part of the risks, including by the provision of guarantees to the private operator, significant contingent liabilities may arise.

\section{The government intends to expand the role of the private sector in}

infrastructure, initially through limited PPPs. At present, the government is developing a railway project to meet the increased demand for freight transportation from the pulp mill plants. Other projects in the area of transportation are also being considered. Besides providing necessary infrastructure, these projects are expected to build confidence on PPPs to allow expanding the use of this scheme in the future.

\section{The experience with PPPs in other countries, both in and outside the region,} provides useful lessons. Chile and Colombia have had PPP programs for a number of years and are setting the standard for the region (Box 3), Brazil is advancing with PPPs, particularly at the state level, and Peru has recently relaunched its PPP program with new road concessions. In addition, a number of advanced economies have now well-developed PPP programs, especially the United Kingdom, Portugal, and Australia, while many others have PPP programs at a more limited scale.

\section{International practice points to the importance of a sound legal framework} that covers all aspects of the PPP process. For example, the comparative success of Chile's concessions program can be largely attributed to the existence of a comprehensive concessions law that addresses the basic requirements for effective concessions (the bidding process, rights and obligations of parties, property appropriation, etc.) as well as possible disputes and the cancellation and transfer of contracts. Brazil has recently enacted a PPP law and Colombia is in the process of strengthening related legislation. The literature 
finds that PPP contracts have been less likely to get renegotiated when the regulatory framework was embedded in a law ${ }^{4}$.

\section{Box 3. PPPs in Colombia and Chile}

Colombia provides an interesting example of large fiscal costs related to poor design of PPPs, which led to significant improvements in the institutional framework.

- $\quad$ Since the early 1990 s, some 150 contracts for private participation in infrastructure service provision have been awarded, with estimated investments of about US $\$ 5$ billion. Contractual approaches used include Build-Operate-and-Transfer, concessions, joint ventures, and licenses. A first generation of projects, up until 1997, included significant demand guarantees motivated by the need to attract investors in an unknown market. A number of these guarantees were triggered, resulting in cumulative payments of US\$2 billion to date. The three most important examples are the Power Purchase Agreements for electricity generation, the Telecom joint ventures, and the first generation of toll roads.

- $\quad$ The lessons of this experience are reflected in the second generation of PPPs, from 1998 onwards, which have been based on a much more substantial transfer of risk to the private sector, with only sparing use of government guarantees. This second generation of projects was embedded in a new legal framework, requiring full accounting and disclosure of contingent liabilities and setting guidelines for the allocation of risks between private and public parties.

Chile has had an overall successful experience with PPPs. The concessions program in Chile covers 44 contracted projects, in transportation and other areas, with a total value of US $\$ 5.7$ billion. In several of these contracts, the government provides a minimum revenue guarantee to concession operators, and in return, the concession firm enters into a revenue sharing agreement by which it shares revenue with the government once a threshold is exceeded. Chile's success with PPPs has been underpinned by a solid institutional framework, well-developed procedures to identify, evaluate and tender projects, efforts to ensure adequate risk sharing of risks between the public and private sectors; and reforms to ensure the availability of private financing for projects. The legal framework is based on the 1991 Concessions Law, which requires competitive bidding for concession contracts, establishes the rights and obligations of parties to contracts, facilitates private property appropriation with full compensation, specifies dispute resolution procedures, and provides for the cancellation and transferability of contracts.

\section{As Uruguay gains experience with its initial projects, it should consider} developing a unified legal framework for PPPs. At the moment, Uruguay has a limited legal framework. Private equity participation and/or association with SOEs is authorized by the Constitution, subject to congressional confirmation. However, current laws set only very general terms for concessions granted by the government and by SOEs. The conditions for each project are largely left to individual implementation decrees and contracts.

\footnotetext{
${ }^{4}$ See J.L. Guasch (2004).
} 
28. International experience also indicates that the institutional framework could be strengthened by setting a central PPP unit and a gateway procedure for PPPs. Central PPP units exist in Chile and Brazil. Their purpose is to acquire and share expertise on negotiation and management of contracts, provide oversight and avoid duplication of efforts, and establish a single point of contact for the agents involved in PPPs. Uruguay is in the process of setting up such a unit at the Ministry of Finance. The authorities should also consider establishing a gateway procedure by which the Ministry of Finance would have veto power to stop PPPs that do not offer value for money or could endanger overall fiscal sustainability.

29. Proper project evaluation is key for the success of PPPs. This process involves two stages: first, appropriate investment planning and project appraisal should determine the viability of a project; next, it should be decided whether a viable project is best suited to be implemented as PPPs or through public procurement. To this end, the use of public sector comparators, to evaluate which of these two alternatives provides better value for money for the government, is the best practice ${ }^{5}$. In the region, Chile is increasingly relying on them. Evidence suggests that PPPs are better suited to provide economic infrastructure (e.g., roads, railways, ports, etc.) as opposed to social infrastructure (e.g., hospitals, schools, etc.).

30. Equally important is to ensure adequate treatment of the risks related to PPPs. PPP contracts should allocate the different risks involved to the party best suited to manage them. Construction and operation risks are typically borne by the private sector. The government should bear risks under its control, like regulatory and political risks. Others, like demand, exchange rate, and residual value risks may or may not have to be borne by the government. Colombian regulations are a good example on how to assign risks. When providing guarantees is appropriate because the government should bear the risks, they need to be valued and factored into the debt sustainability analysis, as they may entail large contingent costs. Chile and Colombia have developed sophisticated valuation techniques ${ }^{6}$, treating guarantees as a financial option. These countries, as well as Brazil, have set up separate funds to reduce the exposure of the private partners if guarantees are called.

\section{To capture fiscal risks, PPPs should be adequately reflected in the fiscal} accounts and information on known and potential costs of PPPs disclosed. Currently no accepted international accounting and reporting standards for PPPs exist. However, the IMF (2005a) provides recommendations in this area to ensure comprehensive disclosure of PPP transactions for the public finance and incorporation in the debt sustainability analysis. In particular, the paper recommends that for PPPs that are recorded as private investments ${ }^{7}$,

\footnotetext{
${ }^{5}$ See U.K. Treasury (2004).

${ }^{6}$ These techniques and their application in Chile are described in IMF (2005c).

${ }^{7}$ According to the 2004 Eurostat decision public-private association projects should be classified as nongovernment assets and recorded off-balance sheet for the government under two conditions: the private partner bears the construction risk and either of the availability or demand risk.
} 
known and certain payment obligations of both parties be taken into account in the budget and the expected net present value of contingent payments be recorded as primary expenditures. For projects recognized as public investment, the service component of future payments under the contract should be counted as primary spending, while the debt service component should be separated out and included in the overall projected interest and amortization payments.

\section{F. Concluding Remarks}

32. Satisfying infrastructure needs will require increased public and private investment. With a still high level of debt, higher public investment will require creating fiscal space by increasing public saving, through lower current expenditures and improved efficiency of spending, especially by strengthening investment procedures. But given fiscal constraints, improving infrastructure to desired levels will be difficult without increased private sector participation. To this end, the government needs to put in place a friendly business environment and a solid regulatory framework to attract private interest, establish efficient PPPs, and limit fiscal risks.

33. The government's agenda includes important measures aimed at increasing resources for investment and improving the efficiency of spending. Some fiscal space is being created through increased revenues. In the area of structural reforms the government is: (i) working with the IDB on strengthening the investment process, in particular by creating a centralized database of investment projects and reinforcing appraisal capabilities to allow better prioritization; (ii) working towards strengthening procurement practices and expanding the use of online tools to improve spending efficiency; and (iii) developing a plan to upgrade the institutional budget process.

34. Uruguay's cautious approach toward PPP program is appropriate. PPPs could be useful in developing the country's infrastructure. To limit fiscal risks, the government should focus initially on projects that do not involve complex design and construction issues, or difficult risk sharing arrangements. These projects would help to develop a reputation of the government as a trustworthy partner as well as boosting confidence of the Uruguayan society in the positive role to be played by the private sector. 


\section{References}

Aschauer, D., 1989, “Is Public Expenditure Productive?” Journal of Monetary Economics, Vol. 23 (March), pp. 177-200.

Calderón, C., W. Easterly, and L. Servén, 2003, “Latin America's Infrastructure in the Era of Macroeconomic Crises," In Easterly and Servén Eds. The Limits of Stabilization: Infrastructure, Public Deficits and Growth in Latin America. Stanford University Press and World Bank, pp. 21-94.

Calderón, C., and L. Servén, 2004a , "Trends in Infrastructure in Latin America, 19802001," World Bank Policy Research Working Paper 3401 (Washington: World Bank).

— , 2004b, "The Effects of Infrastructure Development on Growth and Income Distribution,” World Bank Policy Research Working Paper 3400 (Washington: World Bank).

Guasch J. L., 2004, "Granting and Renegotiating Infrastructure Concessions: Doing it Right," (Washington: World Bank Institute Development Studies).

Fay M., and M. Morrison, 2005, "Infrastructure in Latin America and the Caribbean: Recent Development and Key Challenges," Vols. I and II (Washington: World Bank).

Hemming R, and others, 2005, "Chile: Experience with Public-Private Partnerships" in Chile: Selected Issues, IMF Country Report No.05/136 (Washington: International Monetary Fund).

International Monetary Fund, 2004, "Public Investment and Fiscal Policy," (www.imf.org).

— , 2004, "Public-Private Partnerships," (www.imf.org).

— , 2005, "Public Investment and Fiscal Policy--Lessons from the Pilot Country Studies," available at http:/www.imf.org/external/np/pp/eng/2005/040105a.pdf

— , 2005, "Public Investment and Fiscal Policy--Summaries of the Pilot Country Studies," available at http:/www.imf.org/external/np/pp/eng/2005/040105b.pdf

— , 2005, “Government Guarantees and Fiscal Risk," available at http:/www.imf.org/external/np/pp/eng/2005/040105c.pdf 
Pereyra, Andrés, 2003, "Marchas y Contramarchas en la Concesión de Carreteras en Uruguay," Documento de Trabajo 16-03, Departamento de Economía de la Universidad de Ciencias Sociales de la Universidad de la República del Uruguay.

Romp, W., and de Haan J., 2005, "Public Capital and Economic Growth: A Critical Survey," European Investment Bank, EIB Papers Vol. 10, No 1, pp. 40-70.

Servén L., 2005, “Fiscal Discipline, Public Investment and Growth," (Washington: World Bank).

U.K. Treasury, Treasury Task Force, 2004, "How to Construct a Public Sector Comparator," Technical Note No. 5.

World Bank, 2005a, "Uruguay - Sources of Growth - Policies for the Development of Human Capital, Integration, Competition and Innovation,” Sector Report, June 2005.

— 2005b, Private Participation in Infrastructure, Online Database available at http://www.worldbank.org

World Economic Forum, 2004, "The Global Competitiveness Report." 


\section{URUGUAY'S GROWTH STORY ${ }^{1}$}

\section{A. Introduction}

1. This chapter assesses Uruguay's growth performance during the last decades. Average per capita growth in Uruguay since the 1960s has been low and volatile, both for regional and international standards. Periods of strong growth have been short-lasting and were followed by deep recessions, closely tracking developments in Argentina. The paper first briefly discusses Uruguay's growth patterns, then reviews the findings from growth accounting studies and assesses the extent to

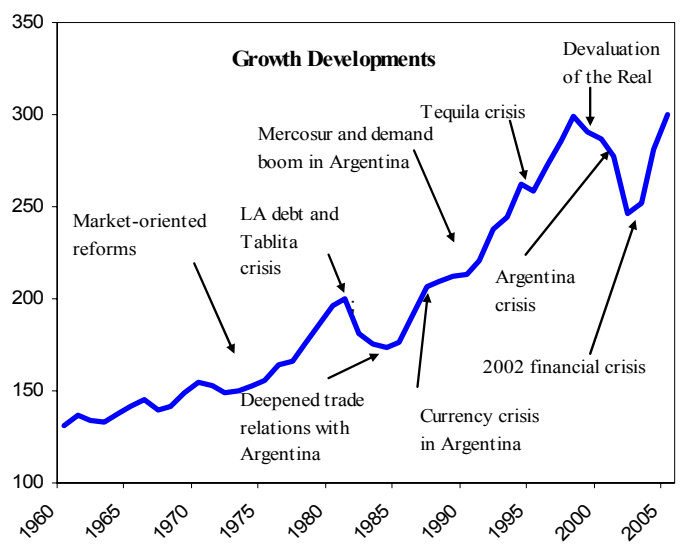
which cross-country regressions explain Uruguay's performance. It then looks more closely at the external factors that have impacted on Uruguay's growth.

2. A key conclusion of the paper is that growth in Uruguay has been supported by increased openness, but adversely affected by the country's exposure to shocks in the region. While policies have been put in place to reduce vulnerabilities, such as a flexible exchange rate regime, diversification of trade and strengthened prudential regulations for the financial system, external risks still remain considerable. Also, domestic factors such as low investment, less developed financial markets and, in the past, volatile fiscal policies have been important constraints to growth. Policies to further improve the investment climate and local capital markets, and consolidate macroeconomic stability will therefore also be key to strengthen Uruguay's medium-term growth outlook.

\section{B. Volatility and Growth Trends—The Facts}

3. Average per capita growth in Uruguay has been low compared to countries outside the region, but also for Latin American standards. Within the region, Uruguay stands out with weak per capita growth in the 1960s; it started to catch up in the 1970s, after Uruguay had implemented market-oriented reforms and opened the economy up to trade. As elsewhere in Latin America, the 1982 debt crisis led to a deep recession in Uruguay, resulting in negative per capita growth during the 1980s. Positive growth has since resumed, but has remained significantly below both the region as well as the Asian and industrialized economies. As a result, Uruguay's per capita income adjusted for purchasing power relative to the U.S. has fallen from 45 percent in 1960 to about 30 percent in 2000.

\footnotetext{
${ }^{1}$ Prepared by Stephanie Eble.
} 


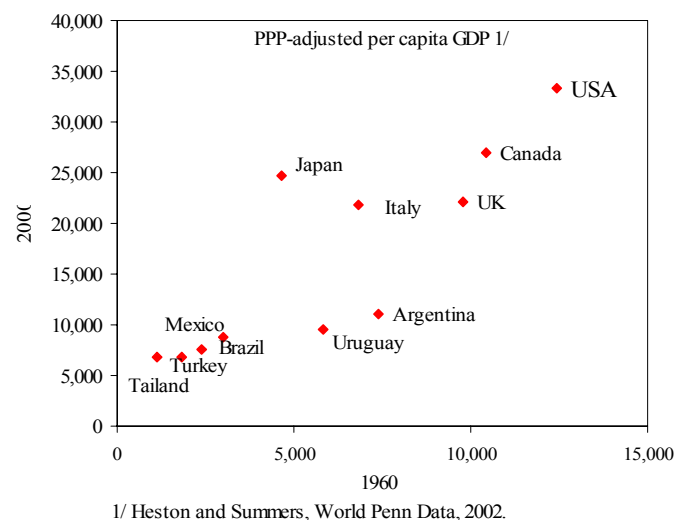

\begin{tabular}{|lccccc|}
\hline \multicolumn{5}{|c|}{ Average Real GDP Per Capita Growth } \\
& $1960-1970$ & $1971-1980$ & $1981-1990$ & $1990-2003$ & $1960-2003$ \\
\hline Latin America & 2.75 & 2.14 & -0.72 & 1.15 & 1.38 \\
Uruguay & 0.78 & 2.62 & -0.66 & 1.04 & 0.99 \\
Brazil & 4.17 & 5.85 & -0.11 & 0.63 & 2.67 \\
Chile & 2.68 & 1.50 & 1.44 & 3.95 & 2.57 \\
Argentina & 2.81 & 1.43 & -3.56 & 2.12 & 1.02 \\
East Asia & 4.18 & 4.98 & 4.25 & 4.06 & 4.29 \\
South Asia & 2.07 & 0.79 & 3.59 & 2.74 & 2.31 \\
Industrial countries & 4.40 & 2.72 & 2.12 & 1.91 & 2.75 \\
Germany & $\ldots$ & 2.60 & 2.09 & 3.07 & 2.65 \\
Japan & 9.57 & 3.24 & 3.58 & 1.29 & 4.24 \\
USA & 2.71 & 2.65 & 2.21 & 1.92 & 2.38 \\
\hline Source: Penn World Table & \multicolumn{5}{c}{} \\
\hline
\end{tabular}

4. Uruguay's economy has followed closely developments in its neighboring countries, particularly Argentina. While before the 1970s, Uruguay's growth performance diverted from its neighboring countries, it has converged since, with Uruguay experiencing the same booms and busts as Argentina did. This may be related to increased regional financial and trade integration (deepened bilateral arrangements in 1985 and establishment of Mercosur in 1991), similar commodity export

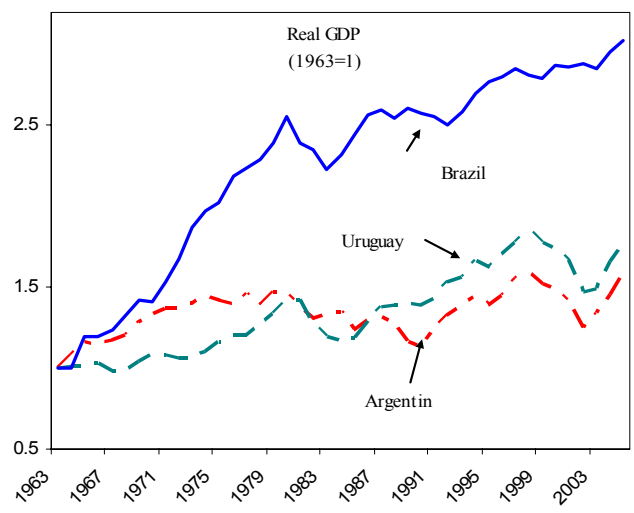
dependencies (beef and wool products), and similar exchange rate policies (Tablita, Argentine Convertibility Plan).

5. Uruguay's growth has been highly volatile. Uruguay's per capita growth has been more volatile than the Latin American average, and in particular compared to other economies outside the region. Volatility in Uruguay has significantly increased beginning in the 1980s, broadly in line with increased volatility in Argentina. This higher volatility could have negatively weighted on long-run growth, as suggested by several empirical studies (see, for example, Loayza et al. (2004)).

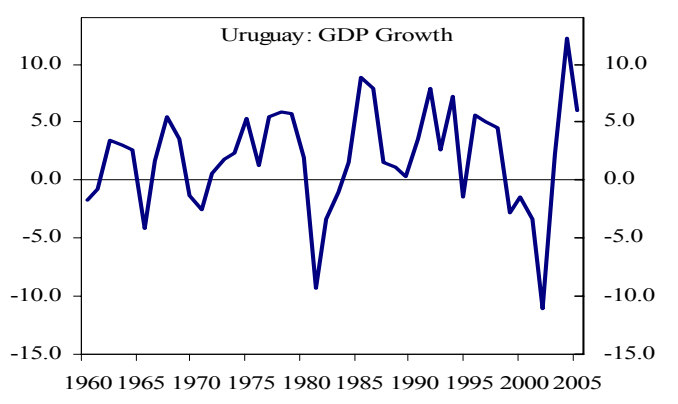

\begin{tabular}{|c|c|c|c|c|c|}
\hline \multicolumn{6}{|c|}{ Volatility of GDP Per Capita Growth 1/ } \\
\hline & $1960-1971$ & 1971-1981 & 1981-1991 & 1990-2004 & 1960-2004 \\
\hline Latin America & 3.67 & 4.39 & 4.59 & 4.03 & 4.62 \\
\hline Uruguay & 3.05 & 2.98 & 6.97 & 5.30 & 4.88 \\
\hline Brazil & 3.02 & 3.27 & 4.11 & 3.05 & 3.90 \\
\hline Chile & 3.61 & 7.81 & 5.87 & 3.22 & 5.22 \\
\hline Argentina & 4.62 & 4.15 & 5.53 & 7.69 & 6.15 \\
\hline East Asia & 4.97 & 2.72 & 3.34 & 3.89 & 4.34 \\
\hline South Asia & 3.40 & 3.98 & 2.04 & 1.96 & 3.23 \\
\hline Industrial countries & 2.47 & 2.74 & 2.21 & 2.15 & 2.73 \\
\hline Germany & $\ldots$ & 2.28 & 1.30 & 3.36 & 2.59 \\
\hline Japan & 2.29 & 2.65 & 1.55 & 1.76 & 3.81 \\
\hline USA & 2.05 & 2.90 & 2.70 & 1.66 & 2.27 \\
\hline
\end{tabular}




\section{Explaining Uruguay's Growth—Traditional Models}

\section{Growth accounting studies for Uruguay suggest that low physical factor} accumulation was a factor limiting growth. For instance, estimates from Bosworth and Collins (2003) show that while annual total factor productivity (TFP) growth has been above Latin American averages, physical capital accumulation has fallen short, explaining Uruguay's low growth performance. This is consistent with investment levels significantly below both regional and international standards. Further, when accounting for human capital measured by the years of schooling or labor income, De Brun (2001) and Fosattie Hughes et al. (2005) find that most of Uruguay's TFP growth can be attributed to it.

\begin{tabular}{|c|c|c|c|c|c|}
\hline & \multicolumn{5}{|c|}{$\begin{array}{l}\text { Average Annual Investment Levels } \\
\text { (in percent of GDP) }\end{array}$} \\
\hline & $1960-70$ & $1971-80$ & $1981-90$ & 1991-2004 & $1961-2004$ \\
\hline Latin American countries & 17.4 & 21.8 & 19.0 & 21.3 & 20.0 \\
\hline Uruguay & 13.1 & 14.3 & 13.1 & 14.6 & 13.8 \\
\hline Brazil & 25.8 & 25.8 & 20.8 & 20.8 & 22.5 \\
\hline Chile & 15.0 & 15.3 & 18.9 & 24.0 & 18.7 \\
\hline Argentina & 21.2 & 23.0 & 18.8 & 17.6 & 20.0 \\
\hline East Asia & 20.2 & 29.8 & 31.7 & 30.4 & 29.3 \\
\hline South Asia & 16.0 & 16.1 & 19.8 & 21.6 & 18.6 \\
\hline Industrialized countries & 25.5 & 25.9 & 23.1 & 21.0 & 23.8 \\
\hline Germany & 26.6 & 23.3 & 22.7 & 22.3 & 23.9 \\
\hline Japan & 35.0 & 33.8 & 29.8 & 27.4 & 31.2 \\
\hline USA & 20.5 & 20.6 & 20.3 & 18.9 & 20.0 \\
\hline
\end{tabular}

\begin{tabular}{|lccc|}
\hline \multicolumn{4}{|c|}{ Growth Accounting-International Comparison 1/ } \\
& GDP per & Physical & TFP \\
\hline worker & Capital & \\
\hline Latin American & 0.83 & 0.44 & 0.38 \\
Uruguay & 0.93 & -0.06 & 0.99 \\
Brazil & 1.77 & 0.79 & 0.99 \\
Chile & 2.17 & 0.76 & 1.39 \\
Argentina & 1.02 & 0.74 & 0.29 \\
East Asia & 3.43 & 2.13 & 1.27 \\
South Asia & 2.23 & 1.04 & 1.18 \\
Industrialized countries & 2.34 & 0.99 & 1.33 \\
Germany & 2.40 & 1.12 & 1.26 \\
Japan & 4.01 & 2.37 & 1.59 \\
USA & 1.66 & 0.36 & 1.29 \\
\hline Source: Data from Bosworth and Collins (2003) \\
1/ Unweighted averages. \\
\multicolumn{4}{|c}{} \\
\hline
\end{tabular}

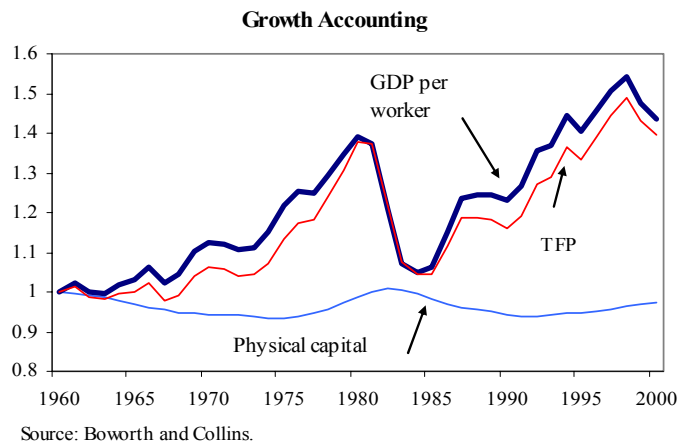

7. Uruguay's long-run growth performance is well explained by standard crosscountry growth regressions (Table 1, Appendix). First, the relevance of key growth determinants as identified by Sala-i-Martin (2004) is tested in explaining Uruguay's average growth performance during 1960-2000. Including variables such as the conditions in 1960 for income, education, the fraction of tropical area, the density of population in coastal areas, the share of mining in GDP and cost of investment, the years an economy has been open, about 55 percent of average cross-country growth in 1960-2000 can be explained. A dummy for Uruguay is included, which is statistically insignificant, pointing to the fact that Uruguay's growth is well explained within the standard regression framework. 
8. Other characteristics could further help explain Uruguay's growth.

- $\quad$ Fiscal policy volatility. Mody and Schindler (2005) conclude in a cross-section study that high fiscal policy volatility has negatively affected growth. In the case of Uruguay, while the fiscal deficit has been contained, overall fiscal policy volatility relative to other countries has been significant.

- $\quad$ High vulnerability to international liquidity conditions. There is a substantial literature on the link between external conditions and balance of payment pressures on growth. Rodrik and Velasco (1999) established that almost all countries affected by the financial turmoil of the 1990s had low ratios of international reserves to short-term external debt prior to the crisis, making them vulnerable to sudden stops, with sharp impacts on growth. Comparing an indicator of external liquidity of Adrogue et al. (2006) (reserves to external debt ratio) across countries, Uruguay stands out with its low liquidity ratio and its high volatility.
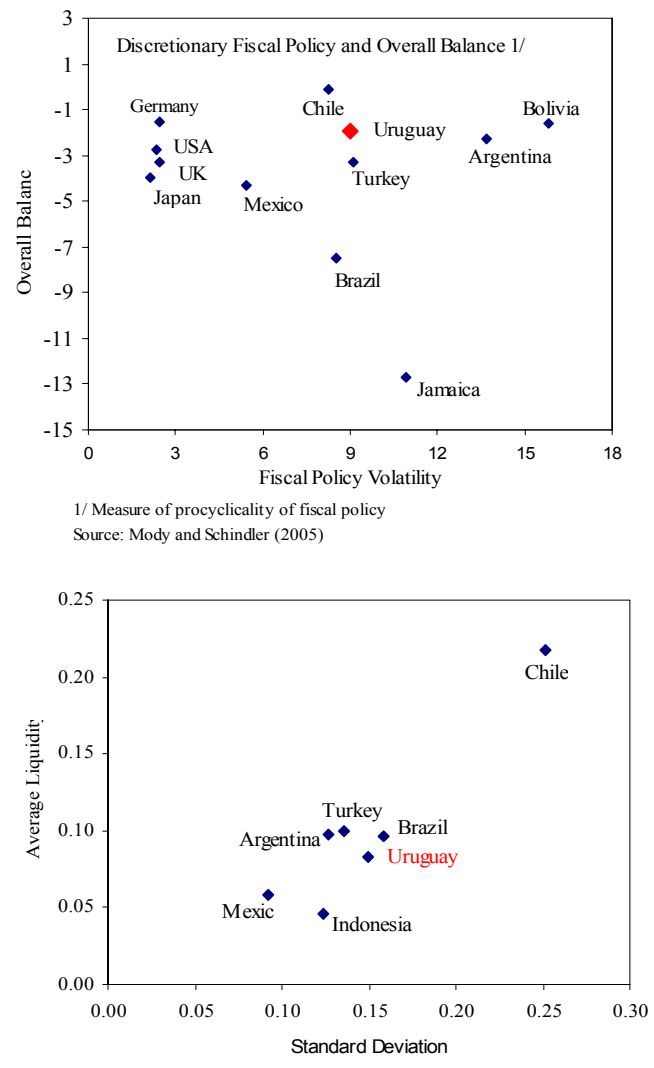

- $\quad$ Terms of trade volatility. Mendoza (1997), for example, finds that terms of trade volatility is important in explaining a country's long-term growth performance, capturing the external demand for exports. Uruguay's terms of trade volatility has been high in an international comparison.

- $\quad$ Limited financial markets. There is a wide literature on the link between financial development and growth. ${ }^{2}$ To date, Uruguay does not have a well-developed stock market or market

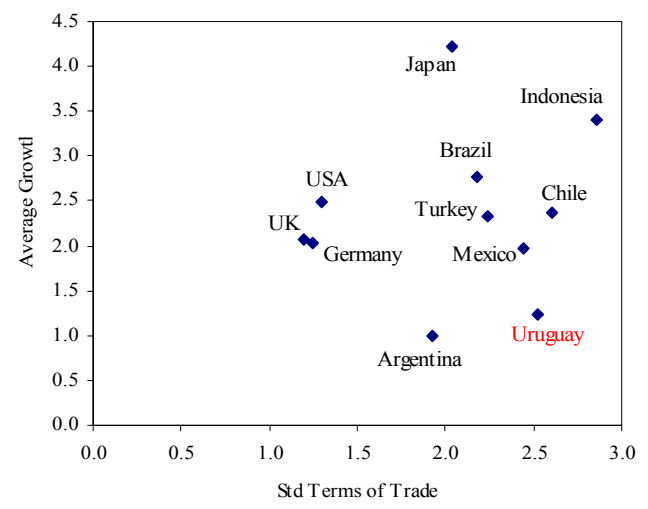
for fixed-income instruments. As a result, firms have relied mainly on domestic bank lending as well as foreign funds and retained earnings as sources of financing. While the private sector credit-to-GDP ratio has been broadly in line with other Latin American countries, with about 27 percent, it has been significantly below the one of the OECD countries.

\footnotetext{
${ }^{2}$ See, for example, King and Levine (1993); Levine, Loayza and Beck (1999); and Levine (2005).
} 
9. Adding these additional growth determinants to the cross-country regressions helps to further improve the fit of the model. In particular, the explanatory power increases significantly when external variables, such as the volatilities of the terms of trade and liquidity is added. Equations 2-12 point to the following correlations:

\section{Domestic factors}

$>$ Growth is positively correlated with the level of private credit.

$>$ Growth is negatively correlated with fiscal volatility.

\section{External factors}

Growth is positively correlated with the degree of openness of the economy, but negatively with terms of trade volatility.

Growth is positively correlated with better liquidity conditions, but negatively with the volatility of liquidity and the level of external debt.

\section{Impact of External Factors on Uruguay's Growth-A Closer Look}

10. Increased openness has helped spur Uruguay's growth. There is a large empirical literature suggesting that openness to trade and financial integration has a positive impact on growth. This is also supported by the cross-country regressions in the previous section. In Uruguay, international trade and financial integration increased significantly in the mid1970s, when trade linkages with the region strengthened, tariff and non-tariff import barriers were reduced, and the capital account was opened. Following this, growth in Uruguay increased significantly, as it allowed Uruguay to benefit from economies of scale, efficiency gains from increased competition, strong external demand, and augmentation in financing. Economic openness has further increased since, initially with Mercosur during the 1990s, and since 2001 with deepening of trade relations with the U.S., the

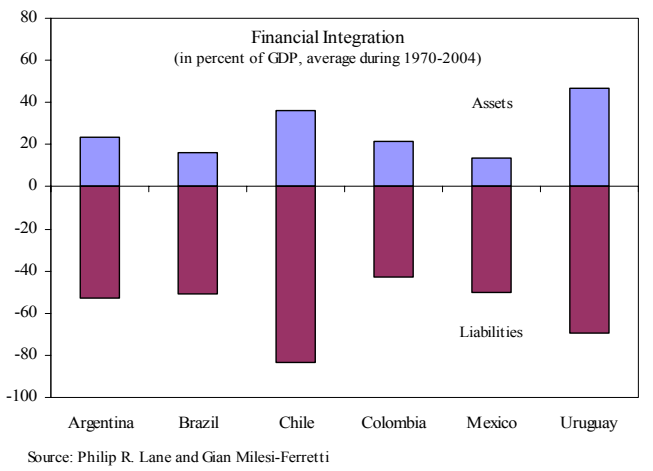
European Union and Mexico. Both imports and exports amounted to about 30 percent of GDP in 2005, making Uruguay a fairly open economy by regional and international standards. 

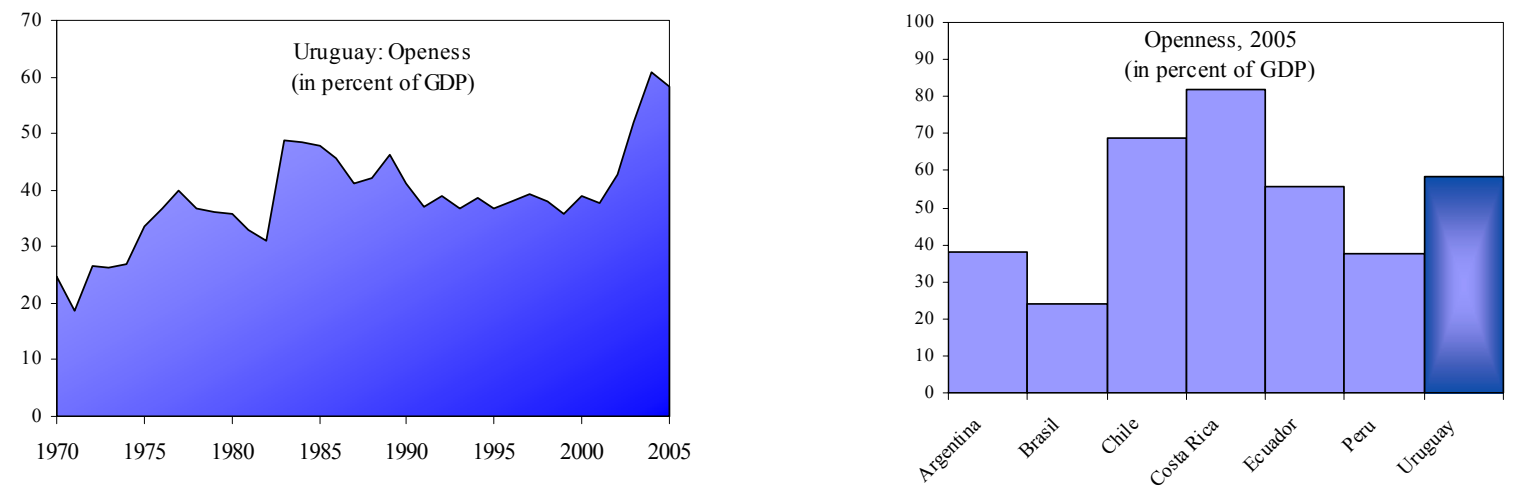

11. At the same time, Uruguay's openness and the structure of its economy have made it vulnerable to developments in the region, commodity prices, and international interest rates. In a nutshell, it features high export market concentration, high financial linkages, large real exchange rate volatility, commodity dependency and dollarization. While many vulnerabilities have been declining over the last years, they remain large relative to other economies.

- $\quad$ Export market concentration. Uruguay's export dependency on the region had increased significantly in the 1990s, with goods exports to Argentina and Brazil reaching 60 percent of total exports in 2000, compared to 35 percent in 1990. While this share has dropped sharply over the last years with increased exports to the U.S. and the European Union, as noted above, concentration is still high compared to other countries (Table 2, Appendix). Further, about 60 percent of Uruguay's tourist industry (which accounted for about 4 percent of GDP in 2005) depends on visitors from the region.

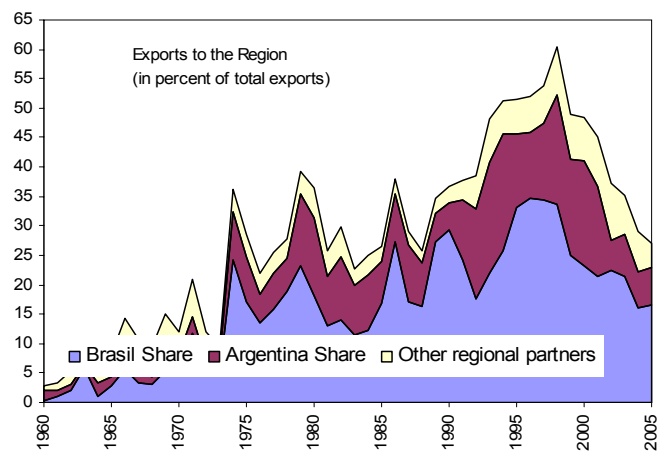

- $\quad$ Strong financial linkages with Argentina. Uruguay has attracted fewer foreign portfolio investors than other countries in the region, owing in part to its less developed capital markets. This has reduced risks of herding behavior and speculative flows. At the same time, Uruguay's financial linkages with Argentina were particularly high, and increased significantly during the 1990 s, with nonresident deposits mainly from Argentines accounting for 40 percent of banking system deposits (or 35 percent of GDP) in 2001. While this brought some benefits - such as rapid growth of the

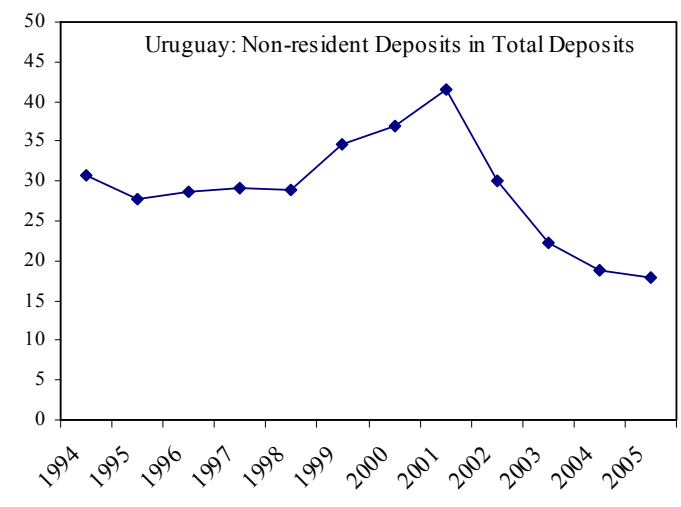
financial service industry - it also made the financial system highly vulnerable to 
sudden withdrawals as demonstrated during the 2002 crisis. Also, Argentine demand for real estate in Uruguay has been a key driver of asset price booms and busts. Today, financial linkages with Argentina have been reduced significantly and prudential regulations have been put in place to limit the linkages to the local economy (Box 1); nevertheless, they remain important, with nonresident deposits accounting for 17 percent of total deposits (10 percent of GDP).

\begin{tabular}{|c|c|}
\hline \multicolumn{2}{|c|}{ Box 1: Measures Taken to Reduce the Risks associated with Financial Linkages } \\
\hline Objective & Measure \\
\hline $\begin{array}{l}\text { Control liquidity risk from cross-border } \\
\text { exposure }\end{array}$ & $\begin{array}{l}30 \text { percent liquidity requirements for non-resident } \\
\text { deposits (replacing average } 25 \text { percent reserve } \\
\text { requirements). }\end{array}$ \\
\hline $\begin{array}{l}\text { Control credit risk arising from cross-border } \\
\text { exposure }\end{array}$ & $\begin{array}{l}\text { Limits imposed on country exposures, implicitly } \\
\text { limiting the exposure to Argentina. }\end{array}$ \\
\hline $\begin{array}{l}\text { Control cross-border risks, including risks } \\
\text { from the operation of cross border financial } \\
\text { conglomerates }\end{array}$ & $\begin{array}{l}\text { Signed memorandum of understanding with the } \\
\text { banking supervisor of Spain; initiated discussion to } \\
\text { sign one for Argentina. }\end{array}$ \\
\hline
\end{tabular}

- $\quad$ Fixed exchange rate regimes. Loayza et. al (2004) show in cross-country studies that real exchange rate overvaluation has negatively impacted growth by producing misallocation of resources and increasing the risk of a balance-of-payments crisis. In the case of Uruguay, the depreciations of the Argentine peso in the early 1980s and 1991 resulted in sharp real appreciations of the Uruguayan peso and a loss in exports to and increase in imports from Argentina, leading to deep recessions. Similarly, during the crawling band of the 1990s when the Brazilian real in 1999 and the Argentine peso in 2001 were devalued, the

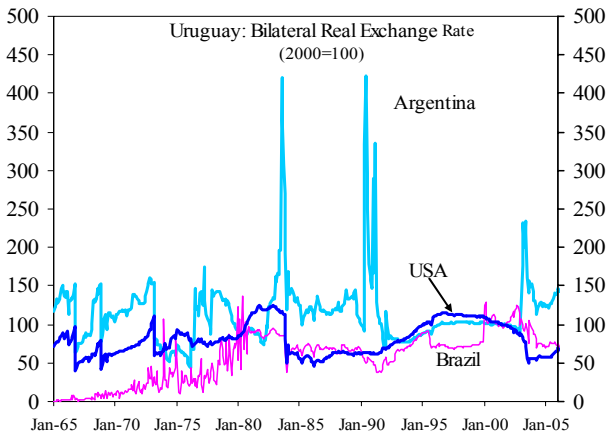
Uruguayan peso appreciated significantly in real effective terms, contributing to a loss of export competitiveness (see Chapter III). Today, Uruguay and its neighbor countries have floating regimes, increasing the ability to absorb shocks.

- Commodity dependency. About half of Uruguay's exports are agricultural commodities (15 percent of GDP), which are subject to large price fluctuations in international markets. In particular, prices of beef (in real terms) Uruguay's main agricultural export commodity - have fluctuated widely with a standard deviation of 60 percent over the last 40

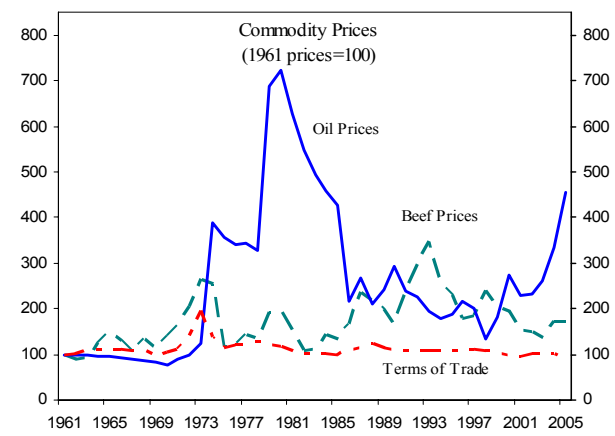


years. Also, Uruguay is fully dependent on oil imports, which accounted for 6 percent of its GDP or one-fourth of its imports in 2005.

- Interest rate linkages. Baliño et al. (1999) point out that in highly dollarized economies - such as Uruguay with 85 percent of financial system assets in dollarsthere is very little room for countercyclical monetary policy, with domestic interest rates sharply influenced by U.S. ones. While efforts are underway to dedollarize the economy through development of local capital markets and domestic currency instruments, currency preferences change only slowly over time.

12. As a result, Uruguay's business cycle correlation with Argentina has generally been very high. ${ }^{3}$ For instance, the correlation of Uruguay's GDP and Argentine consumption growth is high ( 80 percent) and has increased over time. The correlation is about 30 percent with Brazil, and 10 percent with the U.S. Argentine and U.S. consumption clearly Grangercause Uruguay's GDP, but Brazil's consumption does not (Table 3, Appendix). A VAR estimated on logs of Uruguay's GDP and Argentine and U.S. consumption for the time period 1985-2005, shows that about 80 percent of the variance in Uruguay's GDP in a twoyear horizon is explained by Argentine consumption and 10 percent by U.S. consumption. ${ }^{4}$ Further, Argentine consumption and Uruguay's GDP are strongly cointegrated, with an elasticity of 1.0, whereas the one with U.S. consumption is about 0.1 (Table 4, Appendix). Moreover, 65 percent of the deviation of the Uruguayan GDP from the long-run relationship is corrected within one year, suggesting a very fast pass-through of changes in Argentine consumption to the Uruguayan economy.
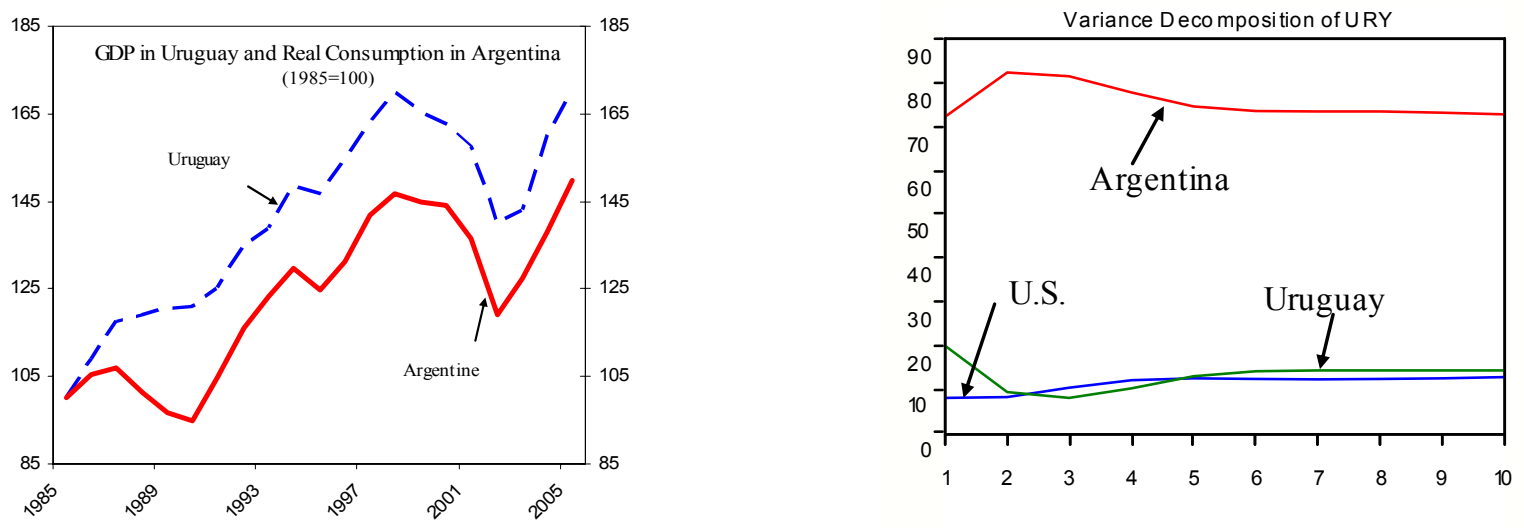

\footnotetext{
${ }^{3}$ See Fanelli and Gonzalez-Rozada (2003), Voelker (2004), Kamil and Lorenzo (1998), and Masoller (1998).

${ }^{4}$ Brazilian consumption was not significant in the long-term cointegrating relationship and thus excluded. This is in line with the findings of Fossati Hughes et al. (2005). Also, Masoller (1998) finds that Uruguay's GDP is mainly explained by Argentine consumption.
} 
13. VAR analysis further suggests that besides Argentine consumption the terms of trade have played a significant role in determining Uruguay's short-term growth. We test to what extent Uruguay's GDP growth is explained by other external variables by including the terms of trade, the REER, and U.S. Libor rates in the VAR. The results show that an increase in Argentine consumption and improvements in the terms of trade have a strong positive impact on Uruguay's growth, and an increase in U.S. interest rates or of the real exchange rate have a negative impact. The results also suggest that Argentine consumption has the largest impact on Uruguay's GDP, with 50 percent of Uruguay's growth variance within a two-year time horizon explained by it, followed by the terms of trade with 20 percent, U.S. interest rates with 10 percent, and the real exchange rate with 5 percent.

Accumulated Response of GDP to Cholesky One S.D. Innovations

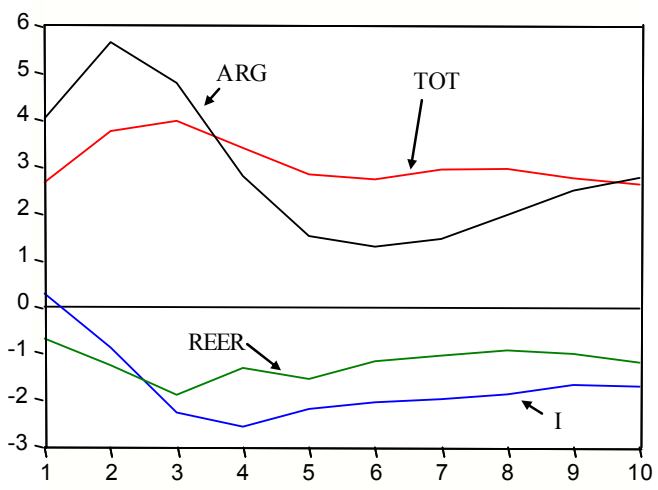

Variance Deœ mposition of GDP

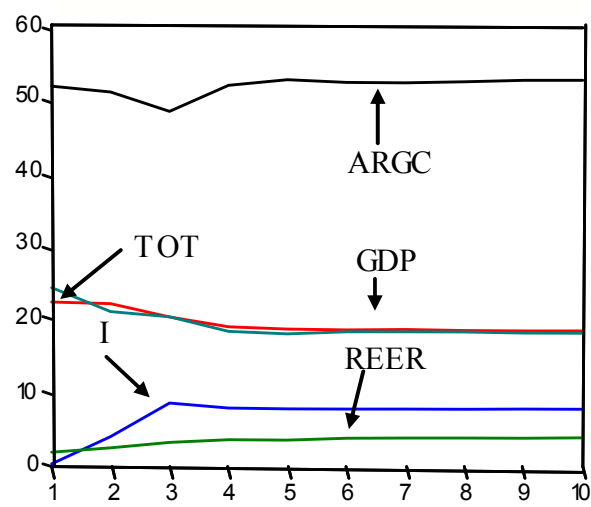

\section{E. Conclusions-Looking Ahead}

14. Uruguay's growth performance is characterized by low long-term rates, high volatility, and close correlation with Argentina. This pattern is well explained by domestic and external factors.

- Domestic conditions, such as less developed financial markets, low investment, and volatile fiscal policies have contributed to Uruguay's low long-term growth rates. Much of Uruguay's long-term growth performance can be attributed to total factor productivity, with physical capital accumulation significantly below other countries.

- External factors such as openness have been important contributors to growth, reflecting the benefits of economies of scale, external demand, and efficiency gains from increased competition. At the same time, trade and financial integration with volatile economies in the region, commodity price dependencies, and, until recently, fixed exchange rate regimes have made the economy vulnerable to external shocks. 
15. Recent policies have contributed to reduced external growth vulnerabilities, but need to be sustained into the medium term. Trade and financial dependencies to Argentina have been reduced by extending trade beyond Mercosur and by putting prudential regulations in the financial sector in place to internalize cross-boarder risks, but trade linkages to Argentina remain significant and non-resident deposits large. The high public debt has been set on a declining path, and Uruguay continues to rebuild reserves to strengthen its still relatively weak external liquidity position. Further, Uruguay, like its neighboring countries, has switched to a flexible exchange rate regime, reducing the risks of exchange rate overvaluation with possible adverse impacts on exports, and the risks of sudden corrections, which have often led to financial crises followed by deep drops in GDP. While much has been achieved, progress needs to continue to reduce the still significant medium-term risks to growth.

16. Also, further improving domestic conditions would be important to achieve lasting growth. This covers improving the investment climate, including by strengthening the bankruptcy framework and establishing and establishing a private sector relations office, deepening local capital markets, and consolidating macroeconomic stability. The government is also advancing important structural fiscal reforms to ensure a stable fiscal framework and increase room for public investment in the budget. A tax reform is expected to be adopted over the next months which would improve the structure and efficiency of the tax system. Also, Uruguay is working toward private participation in public infrastructure projects, which should further spur efficiency and help increase investment, and is planning to strengthen government procurement procedures. 


\section{References}

Adrogué, R., M. Cerisola, and G. Gelos, 2006, “A Comparative View on Brazil's Long-Term Growth Performance," unpublished manuscript.

Balino, T., and others, 1999, "Monetary Policy in Dollarized Economies," Occasional Paper, No.171 (Washington: International Monetary Fund).

Bosworth, B., and S. Collins, 2003, "The Empirics of Growth: An Update." Brookings Paper on Economic Activity (Brookings Institution).

De Brun, J., 2000, “Growth in Factor Accumulation or Productivity Gains?” ORT, Montevideo.

Easterly, W., 2001, “The Lost Decades: Explaining Developing Countries' Stagnation in Spite of Policy Reform 1980-1998" Journal of Economic Growth, Vol. 6, Issue 2, June 2001, 135-157.

Fanelli, J., and M. Gonzalez-Rozada, 2003, "Business Cycles and Macroeconomic Policy Coordination in Mercosur," CEDES.

Fossati Hughes, F., S. Mantero, and V. Olivella Moppett, 2005, "Determinants of Economic Growth in 1955-2003-A Total Factor productivity Analysis," Working Paper No. CINVE.

Heston, A., R. Summers, and B. Aten, 2002, Penn World Table Version 6.1, Center for International Comparisons at the University of Pennsylvania (CICUP).

Kamil, H., and F. Lorenzo, 1998, "Caracterización de las Fluctuaciones Cíclicas en la Economía Uruguya," Revista de Economía, (May) Vol. 5, No.1, pp.83-140.

King, R. and R. Levine, 1993, "Finance, Entrepreneurship, and Growth: Theory and Evidence," Journal of Monetary Economics, Vol. 32, pp. 513-42.

Kose, M., E. Prasad and M. Terrones, 2004, "How Do Trade and Financial Integration Affect the Relationship between Growth and Volatility?" (Washington: International Monetary Fund).

Lane, P., and G. Milesi-Ferretti, "The External Wealth of Nations Mark II: Revised and Extended Estimates of Foreign Assets and Liabilities, 1970-2004,” IMF Working Paper, forthcoming. 
Levine, R., N. Loaysa, and T. Beck, 1999, "Financial Intermediation and Growth: Causality and Causes, "World Bank Policy Research Working Paper 2059.

Levine, R., 2005, "Finance and Growth: Theory and Evidence" forthcoming in Philippe Aghion and Steven Durlauf, eds. Handbook of Economic Growth. The Netherlands: Elsevier Science.

Loayza, N., and Viktoria V. Hnatkovska, 2004, "Volatility and Growth," World Bank Policy Research Working Paper No. 3184 (Washington: World Bank - Research Department and Georgetown University - Department of Economics).

Loayza, N., P. Fajnzylber, and C. Calderón, 2005, "Economic Growth in Latin America and the Caribbean. Stylized Facts, Explanations, and Forecasts," (Washington: The World Bank).

Masoller, A., 1998, "Shocks Regionales y el Comportamiento de la Economía Uruguaya," Revista de Economía (May), Vol. 5, No.1, pp.141-214.

Mendoz, E. G., 1997, “Terms-of-Trade Uncertainty and Economic Growth,” Journal of Development Economics, Vol. 54, pp 323-356.

Rodrik, D. and Velazco, A. 1999, "Short-Term Capital Flows", paper presented at the ABCDE Conference at the World Bank.

Rodriguez, A., R. Hausmann, and D. Rodrik, "Towards a Strategy for Economic Growth in Uruguay,” Inter-American Development Bank, February 2005.

Sala-i-Martin, X., G. Doppelhofer, and R. Miller, 2004, “Determinants of Long-Term Growth: A Bayesian Averaging of Classical Estimates (BACE) Approach," American Economic Review (September) Vol. 94, No. 4, pp.813-835.

Voelker, J., 2004, "Shocks Regionales, Dependencia Comericial y Desempeno Sectorial de la Economia Uruguaya,” Revista de Economía (May), Vol. 11, No.1, pp. 281-334.

World Bank, 2005, "Uruguay - Sources of Growth - Policies for the development of human capital, integration, competition and innovation," Sector Report, World Bank, Sector Report. 
Table 1: Uruguay: Cross-Country Growth Regressions (1960-2000)

$\frac{\text { Sali-i-Martin }}{1}$

Extended Models

Dependent Variable

Explanatory Variables

Initial GDP

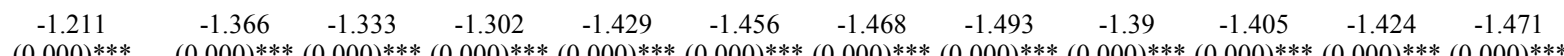

Primary Education

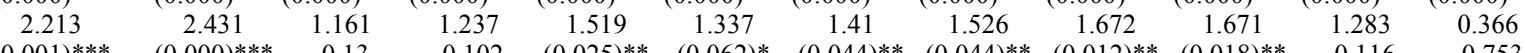

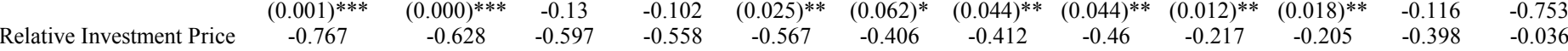

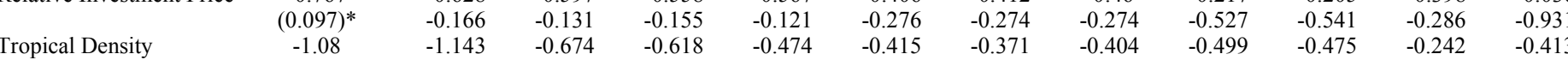

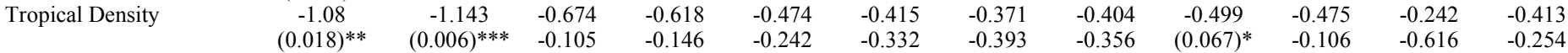

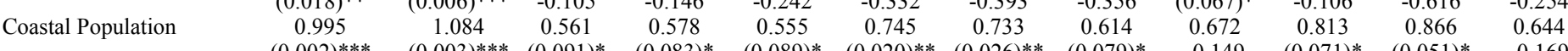

$\begin{array}{lcccccccccccc} & (0.002)^{* * *} & (0.003)^{* * *} & (0.091)^{*} & (0.083)^{*} & (0.089)^{*} & (0.020)^{* *} & (0.026)^{* *} & (0.079)^{*} & -0.149 & (0.071)^{*} & (0.051)^{*} & -0.169 \\ \text { Share of Mining } & 4.9 & 4.053 & 4.332 & 4.402 & 5.219 & 5.757 & 5.723 & 5.812 & 2.279 & 3.273 & 6.064 & 4.869\end{array}$

$\begin{array}{ccccccccccccc} & (0.042)^{* *} & (0.067)^{*} & (0.087)^{*} & (0.085)^{*} & (0.018)^{* *} & (0.006)^{* * *} & (0.007)^{* * *} & (0.006)^{* * *} & -0.425 & -0.275 & (0.001)^{* * *} & (0.042)^{* *} \\ \text { Years Open } & 1.749 & 1.395 & 0.871 & 0.909 & 0.241 & 0.57 & 0.368 & 0.333 & 0.155 & 0.441 & 0.73 & 0.53\end{array}$

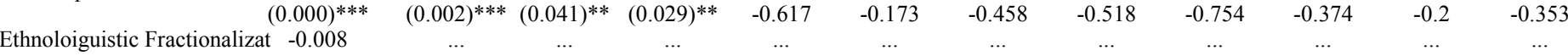

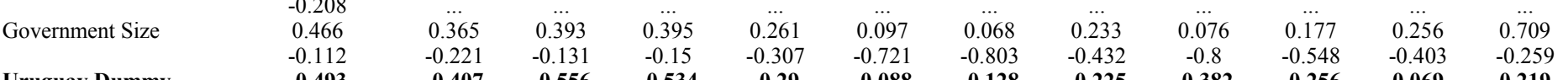

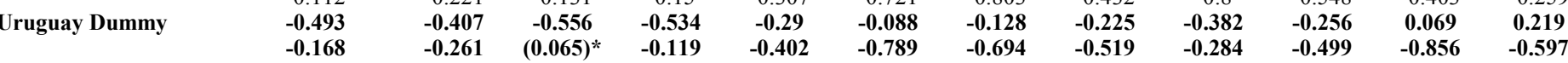

$\begin{array}{llllllllllll}\mathbf{- 0 . 2 6 1} & \mathbf{( 0 . 0 6 5 ) *} & \mathbf{- 0 . 1 1 9} & \mathbf{- 0 . 4 0 2} & \mathbf{- 0 . 7 8 9} & \mathbf{- 0 . 6 9 4} & \mathbf{- 0 . 5 1 9} & \mathbf{- 0 . 2 8 4} & \mathbf{- 0 . 4 9 9} & \mathbf{- 0 . 8 5 6} & \mathbf{- 0 . 5 9 7} \\ & -5.804 & -5.71 & -4.519 & -5.401 & -4.95 & -5.457 & -5.043 & -4.559 & -4.545 & -5.58\end{array}$

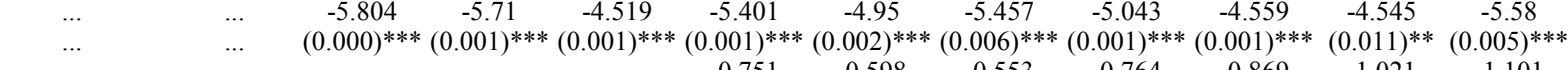

Terms of Trade Volatility

Fiscal volatility

M2/GDP

Private Credit to GDP

Stock market

External debt

Liquidity Ratio

Liquidity Volatility

Real exchange rate

Growth volatility

Political constraints

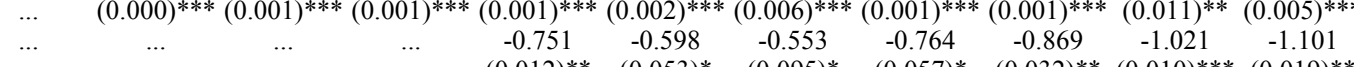

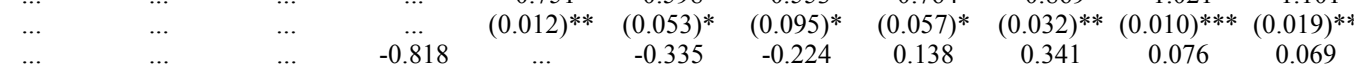

$\begin{array}{ccccccccccc}\ldots & \ldots & \ldots & -0.818 & \ldots & -0.335 & -0.224 & 0.138 & 0.341 & 0.076 & 0.069 \\ \ldots & \ldots & \ldots & (0.022)^{* *} & \ldots & -0.249 & -0.449 & -0.665 & -0.303 & -0.846 & -0.823 \\ \ldots & \ldots & \ldots & \ldots & \ldots & \ldots & \ldots & \ldots & \ldots & \ldots & -0.024 \\ \ldots & \ldots & \ldots & \ldots & \ldots & \ldots & \ldots & \ldots & \ldots & \ldots & -0.159 \\ \ldots & \ldots & \ldots & \ldots & \ldots & \ldots & \ldots & \ldots & \ldots & \end{array}$

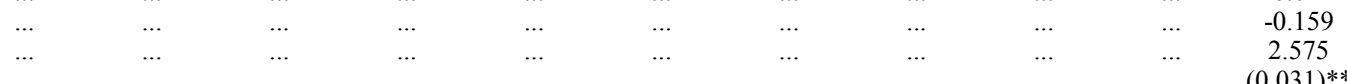

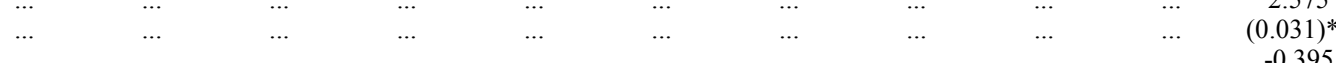

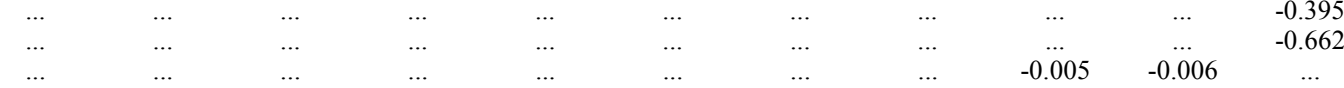

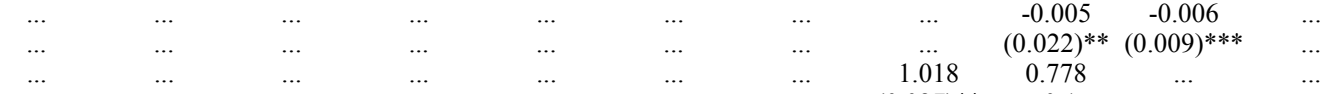

Observations

84

86

$86 \quad 86$

85

$85 \quad 85$

$85-84$

80

$(0.027) * * \quad-0.1$

$\begin{array}{ll}(0.027) * * & -0.1 \\ -0.41 & -0.331 \\ (0.055) * & -0.128\end{array}$

$\begin{array}{ll}-0.41 & -0.331 \\ (0.055)^{*} & -0.128\end{array}$

Robust $\mathrm{p}$ values in parentheses
$*$ significant at $10 \% ; * *$ significant at $5 \% ; * *$ significant at $1 \%$ 


\section{Description of Key Variables in Cross-Country Regressions}

Variable

Terms of trade volatility

International liquidity

Real exchange rate misalignment

Fiscal volatility

Private sector credit

Stock Market Capitalization

Political constraints

\section{Sources and Definitions}

From Loayza et al. (2005). Measured as the standard deviation of the terms of trade.

From Adrogue et al. (2006). Measured as the ratio of gross international reserves to total external debt (in percent).

From Easterly (2001).

From Mody and Schindler (2005).

From Mody and Schindler (2005). Ratio of private credit by deposit money banks/other financial institutions to GDP (in percent).

From Mody and Schindler (2005). Ratio of stock market capitalization to GDP (in percent).

From Henisz (2002).

Table 2: Index of Export Diversification

(share of total exports)

\begin{tabular}{lcccccc} 
& Argentina & Brazil & Chile & Peru & Turkey & Uruguay \\
\hline 3 biggest export market & $36.7 \%$ & $34.6 \%$ & $37.8 \%$ & $48.5 \%$ & $28.2 \%$ & $42.5 \%$ \\
5 biggest export markets & $49.0 \%$ & $43.9 \%$ & $49.0 \%$ & $59.0 \%$ & $40.1 \%$ & $51.0 \%$ \\
\hline
\end{tabular}

Source: Fund staff estimates. 
Table 3: Granger Causality Test 1/

\begin{tabular}{lcc} 
& F-Statistic & Probability \\
\hline URY does not Granger Cause ARG & 0.68 & 0.59 \\
ARG does not Granger Cause URY & 3.03 & 0.08 \\
UR does not Ganger Cause USA & 0.19 & 0.90 \\
USA does not Granger Cause URY & 2.75 & 0.10 \\
URY does not Granger Cause BRA & 1.00 & 0.43 \\
BRA does not Granger Cause URY & 0.68 & 0.58 \\
\hline
\end{tabular}

1/ First differences of the logs of Uruguay GDP and Argentine, Brazilian and US consumption between 1985-2005. Tested for statinarity using the Dickey-Fuller test.

Table 4: Cointegration Vector

Cointegrating Vector

LURY1 $=-0.912+$ LARG +0.132 LUSA

$(0.057)$

Adjustment Factor

$$
\mathrm{a}=0.642
$$

(0.359)

Restrictions

LARG $=1, \quad$ LURY $=-1$
$\mathrm{c}^{2}=\quad 0.00(0.984)$ 